\title{
إشارة الجسل من مظاهر التيسير ورفع الحرج في الفقه الإسلامي
}

\author{
دكتور \\ حليه رجب كمال السيل رداد \\ مدرس الشريعة الإسلامية بكلية الحقوق \\ جامعة كفر الثيخ
}




\section{ملخص البحث :}

تعد الإثارة الصادرة من الجسد إحدى طرق التعبير عن الإرادة، والواقع خير

شاهد على ذللك؛ ولأجل معرفة الدور الذي تقوم به إثارة الجسد في التيسير على المكلفين ورفع الحرج عنهم قمت بإعداد هذا البحث، حيث تطرقت في المبحث الأول إلى مفهوم إثشارة الجسد ثم ذكرت نماذج من إثارة الجسد في القرآن الكريم والسنة المطهرة، ثم في المبحث الثاني قمت بذكر الأدلة على التيسير ورفع الحرج عن المكلفين، وذلك في المطلب الأول، ثم في المطلب الثاني وضحت ضوابط التيسير ، ثم في المبحث الثالث ولغرض إظهار موقف الفقهاء من الاعتداد بإشارة الجسد كأمر يحقق التيسير ورفع الحرج في مجال العبادات قمت بثقسيمه لمطلبين، وضحت في بـ بهاء المطلب الأول إعمال إثارة الجسد أثثاء الصلاة، وفي المطلب الثاني بينت إعمال إثارة الجسد أثناء خطبة الجمعة، ثم في المبحث الرابع ولغرض إظهار موقف الفقهاء

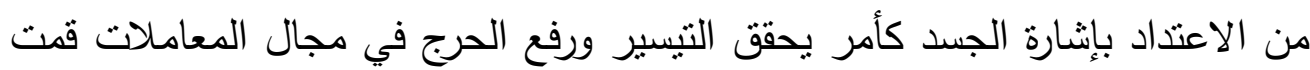
بتقسيمه لأربعة مطالب، في المطلب الأول ذكرت موقف الفقهاء من إثارة الأخرس،

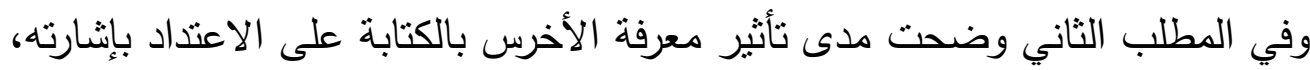
وفي المطلب الثالث بينت موقف الفقهاء من إثنارة معتقل اللسان، وفي المطلب الرابع أظهرت موقف الفقهاء من إثارة الناطق، وبعد ذلك جاءت الخاتمة التي ذكرت فيها أهم النتائج والتوصيات.

$$
\text { الكلمات الكفتاحية: (إثنارة الجسد - التنيسير - الحرج - النطق - اللسان) }
$$




\section{Research Summary}

The signal emanating from the body is one of the ways of expressing the will, and reality is the best witness to that. In order to know the role played by the body signal in facilitating the taxpayers and removing their embarrassment, I prepared this research, where I touched in the first section on the concept of the body signal and then mentioned examples of the body signal in the Holy Qur'an and the Sunnah. Then in the second topic I mentioned the evidence for facilitation and removing embarrassment from the taxpayers, and that was in the first requirement, then in the second requirement the controls of facilitation were clarified, then in the third topic, and for the purpose of showing the position of the jurists regarding the reverence of the body's gesture as a matter that achieves facilitation and removal of embarrassment in the field of worship, I divided it into two demands In the first requirement, the gesture of the body was made clear during prayer. In the second requirement, I showed the implementation of the body gesture during the Friday sermon, and then in the fourth topic, and for the purpose of showing the position of the jurists regarding the reverence of the gesture of the body as a matter that achieves ease and relief in the field of transactions, I divided it into four demands. In the second requirement, it clarified the extent of the impact of al-Akhras's knowledge of writing on the reliance on his sign, and in the third requirement, she showed the position of the jurists on the sign of the tongue detainee, and in the fourth requirement, she showed the position of the jurists on the sign of the speaker, and then came the conclusion in which the most important results and recommendations were mentioned.

Keywords: (body signal- facilitation- embarrassment- pronunciation- tongue) 
الحمد لله رب العالمين، والصلاة والسلام على أشرف المرسلين وخاتم النبيين ورحمة الله للعالمين، سيدنا محمد وعلى آله وصحبه أجمعين، وبعد فإن الله تعالى أكمل لنا الدين وأتم علينا النعمة، ولم يترك عباده سدى يفعلون ما يثاعون، بل رسم لهم الطريق وبين لهم ما يشرع لهم وما يحرم عليهم، وكل ذلك بواسطة كتابه المجيد ونبيه الكريم ومن رضي عنهم من العلماء الأجلاء الذين لم يتركوا شاردة ولا واردة إلا وسبروا أغوارها، ولذلك لا يليق بمؤمن أن يخطو خطوة إلا وهو يتحس قدمه فيها حتى لا يعرض نفسه لمقت الله وغضبه، لا سيما أن شريعة ربه تتصف بالتيسير ورفع الحرج عن المكلفين، فليس فيها أحكام تعسفية تضعه في الضيق والحرج، فالثريعة كما لا يخفى على كل ذي عقل مبناها على تحقيق المنافع للعباد في العاجل والآجل، ورغبة مني في تسليط الضوء على الدور الذي تؤديه إثارة الجسد في التيسير ورفع الحرج عن المكلفين قمت بإعداد هذا البحث.

\section{ويرجع السبب في اختياري لهذا الموضوع ما يلي:}

أولاً: أنني لم أجد من تكلم عن إثارة الجسد من ناحية كونها أداة للتيسير على المكلفين ورفع الحرج عنهم.

ثانيا: أن الحاجة ملحة إلى معرفة الكثير والكثثر من الأحكام الفقهية، فلا يليق بنا أن نسأل يوما عن شيء من هذا الموضوع- وهو إثارة الجسد- ولا يكون عندنا الرد

$$
\text { الكافي في ذلك. }
$$

ثالثا: إظهار الدور الريادي للشريعة الإسلامية، فهي دائما وأبدا سباقة ومنميزة عن كل ما سواها من نظم وضعية، فليس هناك شيء يخطر على قلب إنسان إلا وللثريعة

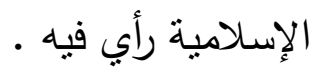




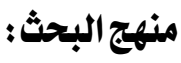

حتى أقوم بيحث هذا الموضوع على الوجه الأمثل قمت بالالتزام بما يلي:

أولا: قمت باتباع الأسلوب العلمي المتمتل في تبويب المادة العلمية المجمعة وتحليلها، ووضعت لكل مسألة عنوانا مع مراعاة أن يكون معبرا عن مضمونها.

ثانيا: قمت بترقيم الآيات القرآنية الكريمة وعزوتها إلى سورها، ورجعت إلى كتب التقسير وأحكام القرآن لأبين وجه الدالائة ما أمكن.

ثالثا: خرجت الأحاديث النبوية الثريفة وكذلك آثار الصحابة تخريجا علميا وفقا للأصول المعتمدة في ذلك ذاكرا أقوال المحدثين في سند تلك الأحاديث والآثار إن وجدت لهم كلاما فيها، وكل ذلك إذا لم يكن الحديث في الصحيحين أو في

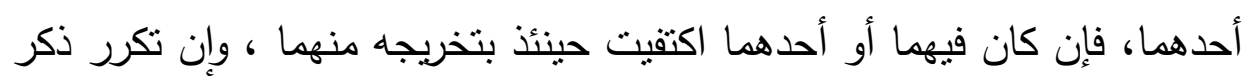
الحديث في موضع آخر في البحث اكتقيت بالإشارة إلى تخريجه.

رابعا: قمت بتجلية الحكم الفقهي للمسألة محل البحث أو التأصيل له باتباع ما يلي: I - إن كان هناك اتفاق في بعض المسألة وبعضها الآخر محل خلاف فإنني أقوم بتحرير محل النزاع.

r - إن كانت تللك المسألة قد تم التتصيص عليها في كتب الفقهاء فإنني أذكر الأفوال فيها مع عزوها لقائلها من أهل العلم، فإن كانت غير منصوص عليها أجريتها على مفهوم المذهب موضحا ذلك.

r - أقوم بعرض الأدلة لكل قول، وأذكر المناقنتات على تلك الأدلة وما يجاب بـ عنها إن وجد ذلك لكعرص

ع - في ختام المسألة أبين القول المختار ، موضحا سبب رجحانه من وجهة نظري. 
خامسا: اعتمدت في جمع وتحرير هذا البحث على المراجع الأصلية وأمهات المصادر

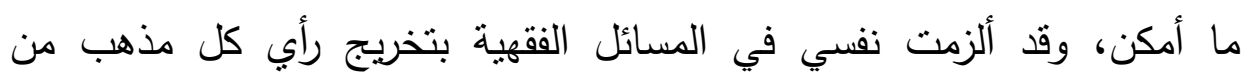

$$
\text { مصادره الخاصة دون الاعتماد على مصادر المذاهب الأخرى. }
$$

سادسا: ختمت الرسالة بخاتمة، وضمنتها أهم النتائج التي توصلت إليها، وأعقبتها

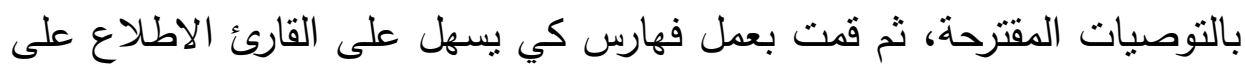

$$
\text { جزئيات البحث. }
$$

خطة البحث:

اقتضت طبيعة البحث أن أتتاوله في مقدمة وأربعة مباحث وخاتمة على النحو التالي:

المقدمة

المبحث الأول: مفهوم إثنارة الجسد المطلب الأول: مفهوم إثارة الجسد النشارة الجند

المطلب الثاني: نماذج من إثنارة الجسد في القرآن الكريم

المطلب الثالث: نماذج من إثارة الجسد في السنة المطهرة المبحث الثاني: دليل التيسير ورفع الحرج عن المكلفين وضابطه المطلب الأول: الأدلة على التيسير ورفع الحرج عن المكلفين المطلب الثاني: ضوابط التيسير

المبحث الثالث: موقف الفقهاء من الاعتداد بإنشارة الجسد في مجال العبادات المطلب الأول: إعمال إثنارة الجسد أثناء الصلاة المطلب الثاني: إعمال إثنارة الجسد أثناء خطبة الجمعة إنمارة الجماء المبحث الرابع: موقف الفقهاء من الاعتداد بإثارة الجسد في مجال المعاملات

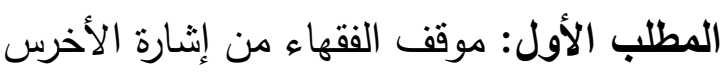
المطلب الثاني: مدى تأثير معرفة الأخرس بالكتابة على الاعتداد بإثـارته المطلب الثالث: موقف الفقهاء من إثارة معتقل اللسان المطلب الرابع: موقف الفقهاء من إثشارة الناطق 


\section{المبحث الأول}

\section{مفهوه إشارة الجسد}

يجدر بنا في البداية أن نتعرف على مفهوم إثارة الجسد، ثم بعد ذلك نذكر

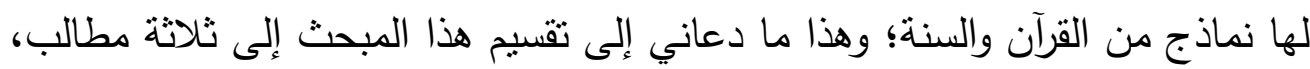
في المطلب الأول أوضح مفهوم إثارة الجسد، وفي المطلب الثاني أذكر نماذج من إثارة الجسد في القرآن الكريم، وفي المطلب الثالث أذكر نماذج من إثشارة الجسد في السنة المطهرة.

\section{المطلب الأول \\ مفهوم إشارة الجسل}

لكي نقوم بتعريف إثارة الجسد لا بد من توضيح معنى اللفظتين المكونتين لهذا

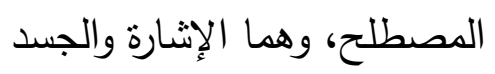
1- عرفت الإشارة لغة بأنها: التلويح بشيء بحيث يفهم منه ما يفهر من النطق، وقيل

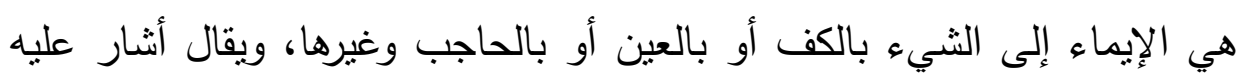

$$
\text { بكذا: أي أبدى له رأيه، والإهم الثورى. بالكم. }
$$

والإشارة عند الإطلاق تكون حقيقة في الحسية، وقد تستعل مجازا في الذهنية، كالإثارة عن طريق ضمير الغائب ونحوه ، فإن عديت الإثارة ب" إلى " تكون بمعنى

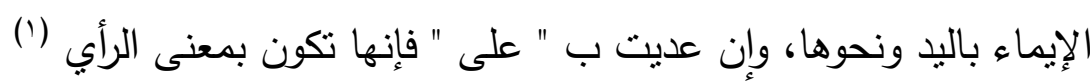

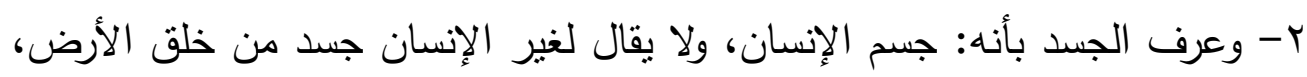

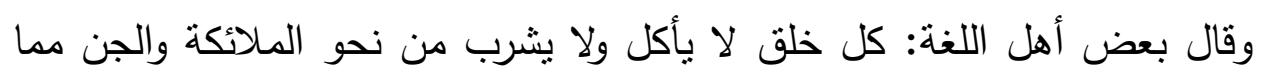

$$
\text { يعقل فهو جسد (r) }
$$

(1) الكليات معجم في المصطلحات والفروق اللغوية: أيوب بن موسى الحسيني القريمي الكفوي،

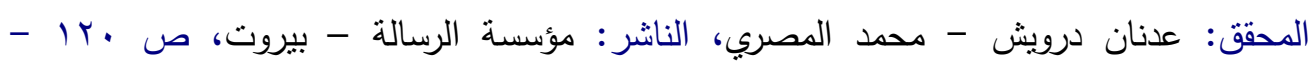

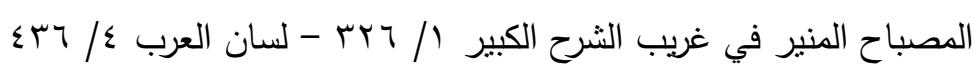

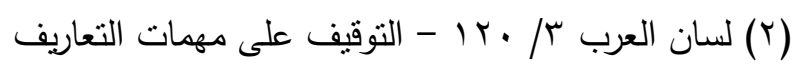




\section{العلاقة بين إشارة الجسل ولفة الجسل :}

إن مصطلح لغة الجسد كما هو واضح مكون من كلمتين هما اللغة والجسد،

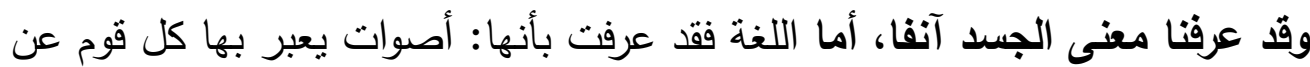
أغراضهم، وأصلها من لغوت إذا تكلمت (')، وقال البعض بأن اللغة هي: الكلام

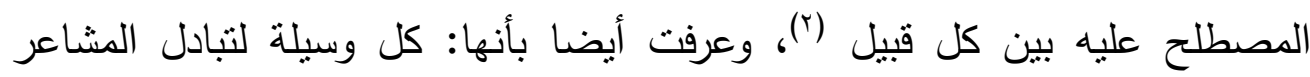

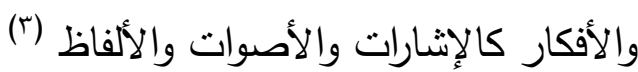
لكن لغة الجسد كمصطلح فقد عرفت بأنها: لغة غير منطوقة، وتقرأ من التعابير التي ينتجها الجسد بطريقة متعددة أو تلقائية، وهي تتألف من الإيماءات والحركات غير اللفظية، والحركات معناها: الإشارات والرموز الصادرة عن الثخص الثص التهنه

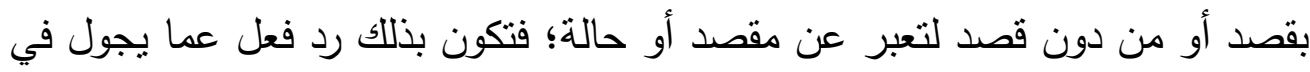

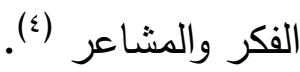

وقال البعض عن لغة الجسد بأنها: لغة غير لفظية، وهي أي حركة ظاهربة للجسد كاملا أو لجزء منه، كحركات العيون وحركات اليدين والأرجل وتعابير الوجه والانحناءات والإثتارات المعينة إما بالرأس أو في الجذع، وهذه الحركات تكون انعكاسية

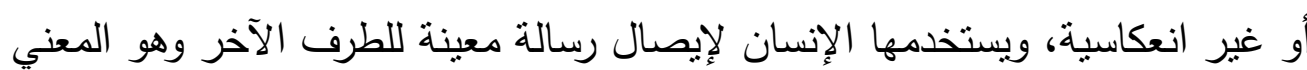

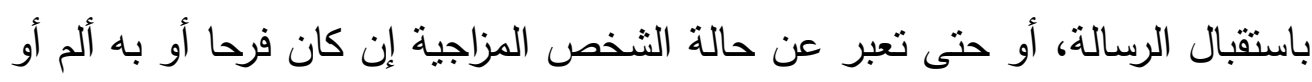
حزن أو كان تعبا أو مرناحا وغيرها من التعابير التي تظهر الحالة النفسية له (०).

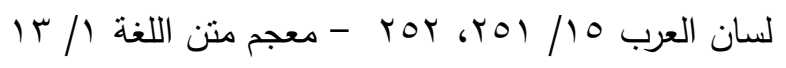

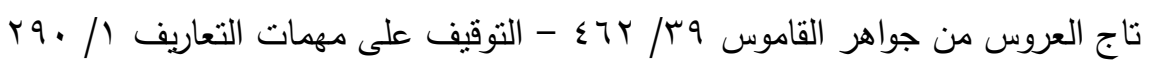

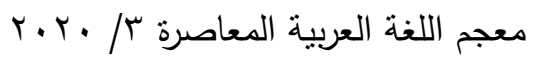

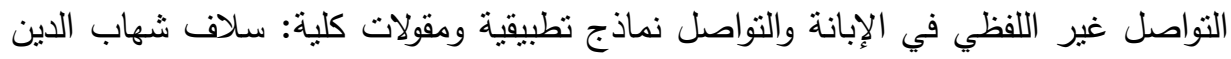

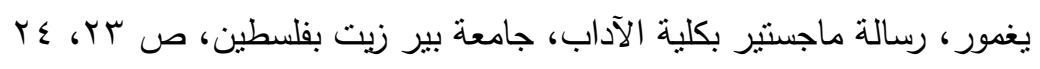

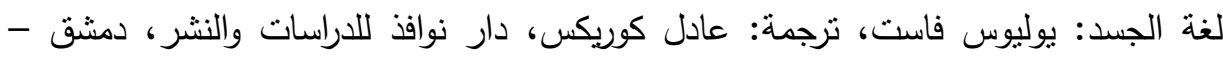

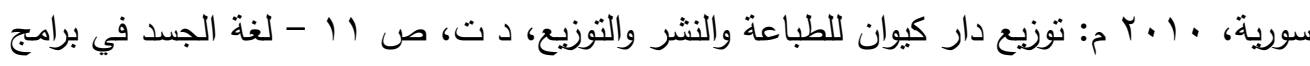

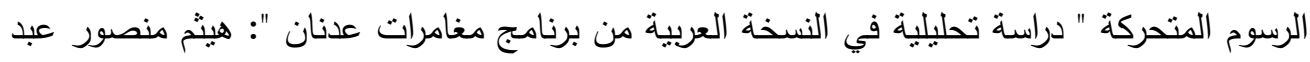


وقيل عن لغة الجسد أيضا: هي تلك الحركات التي يقوم بها بعض الأفراد باستخدام

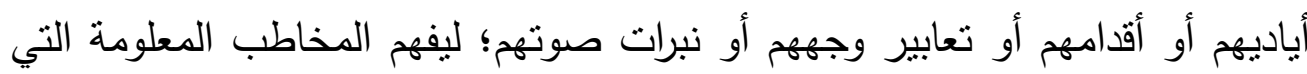

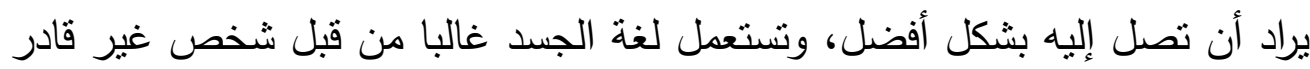
على التعبير عن نفسه بالكلمة فقط، أو يرى المستقبل لا يستطيع استيعاب الكلمات

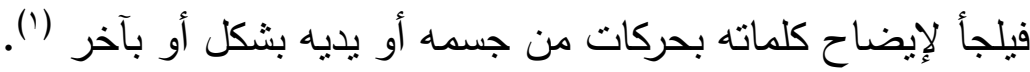
وإن لغة الجسد كما تستخدم منفردة في عملية الاتصال فإنها أيضا قد تستخدم مع اللغة المنطوقة؛ كما لو تقابل شخصان فإنهما يتصلان باللغة المنطوقة وبلغة الجسد التمان

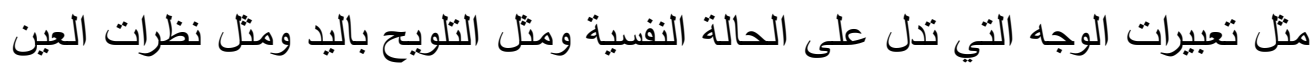

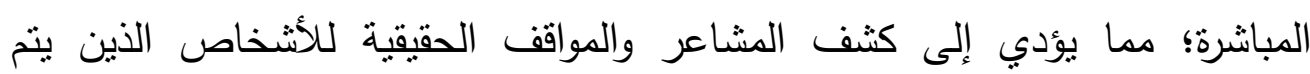

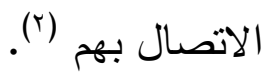
والعجيب أنه أجريت عدة دراسات فيما لو اقترنت اللغة المنطوقة بلغة الجسد، وتوصلت هذه الدراسات إلى أن نسبة التأثير في الآخرين تكون على الوجه التالي:

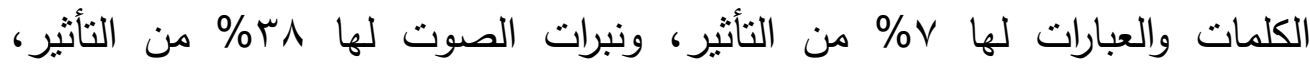

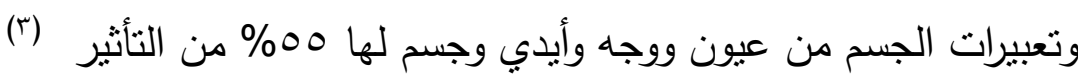

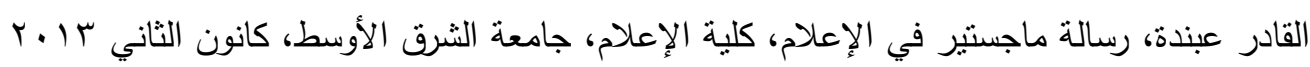
م، ص • r (1) لغة الجسد وأتزها على إنجاز أهداف التفاوض التجاري دراسة ميدانية: عقبة الصباغ، رسالة

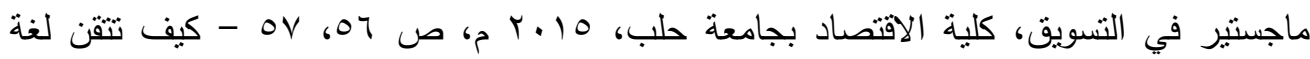

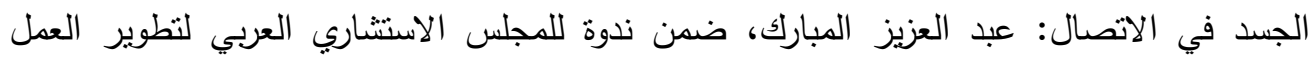

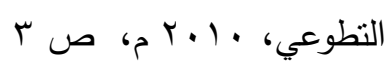

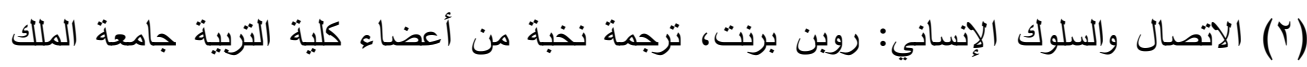

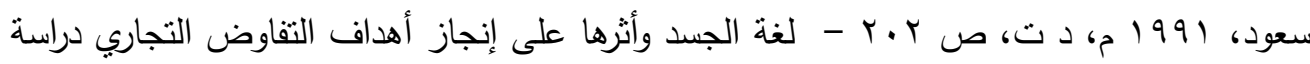

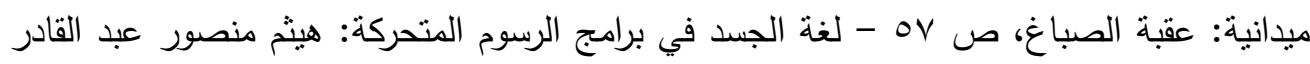
عبندة، ص س

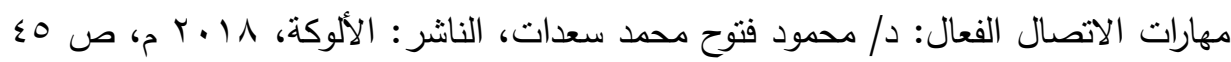

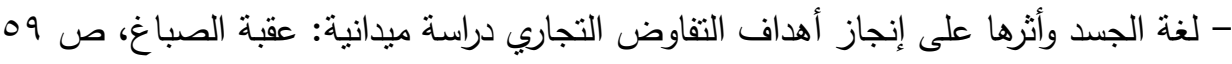


ومما سبق يتضح لنا أن لغة الجسد هي كل ما يعبر عن مكنون الإنسان من

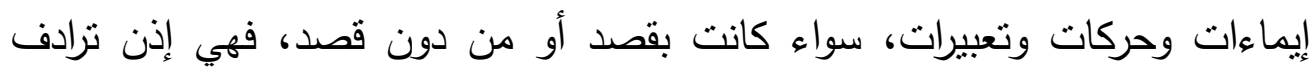
إثارة الجسد؛ فقد سبق أن قلنا بأن الإشارة تعني التلويح بشيء بحيث يفهر منه ما يفهم

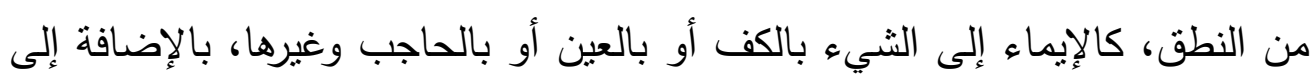

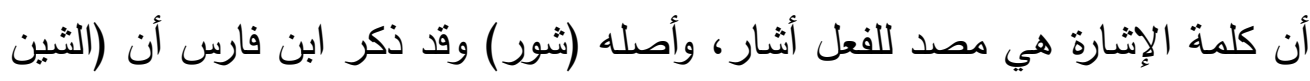
والواو والراء) أصل مطرد بمعنى إبداء شيء وإظهاره وعرضه،، كقولهم: شُرْتُ الدابة إنها

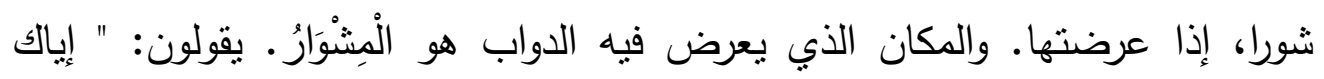

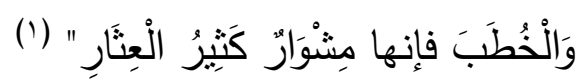

مما يدل على أن كلمة إثارة إذا أضيفت إلى الجسد فإن معناها كل ما يعرضها

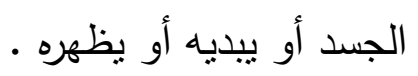
لكننا آثرنا استعمال مصطلح " إثارة الجسد " في عنوان البحث بدلا من " لغة الجسد "؛ لأن كل المسائل الفقهية المعروضة في هذا البحث هي من قبيل الحركات الجسدية التي يفعلها المرء بقصد منه لإيصال معنى معين، ودائما تذكر في كتب هنب

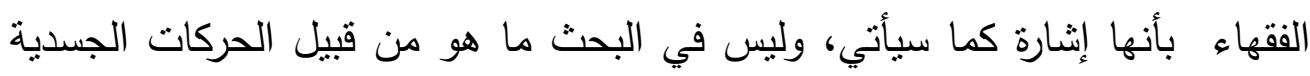

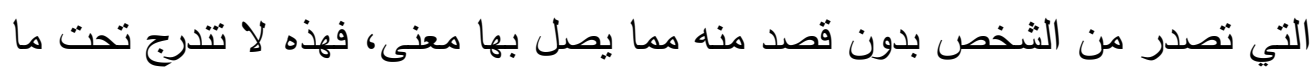

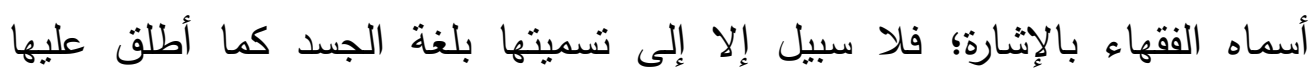
المعاصرون المتخصصون في هذا المجال

(1) معجم مقاييس اللغة: أحمد بن فارس بن زكرياء القزويني الرازي، المحقق: عبد السلام محمد

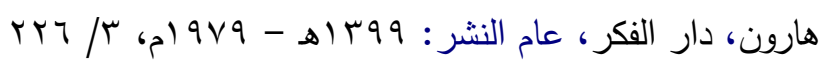




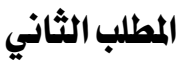 \\ نماذج من إشارة الجسد في القرآن الكريـ}

المنتبع لآي القرآن الكريم يرى فيها ما هو من قبيل إثنارة الجسد، وهذه أمثلة على ذلك ألكان

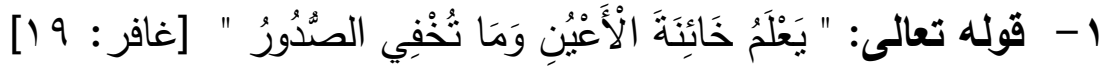

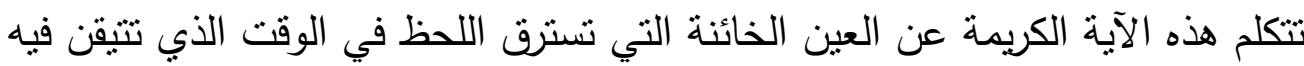
من عدم اطلاع أحد عليها؛ فقد ورد عن ابن عباس في تفسيره لخائنة الأعين أنه قال:

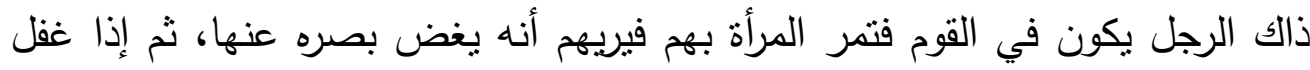
القوم لحظ إليها، وإذا نظروا غض البصر البرم عنها، وهو يود أن ينظر إلى عورتها، والله

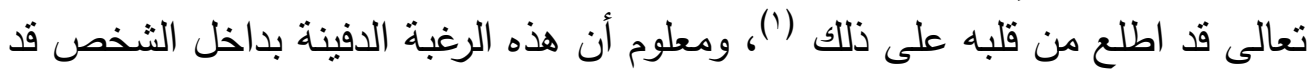
ترجمتها عينه، وهذا من قبيل إثنارة الجسد.

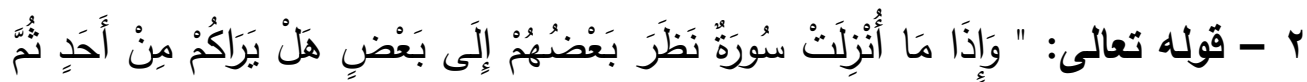

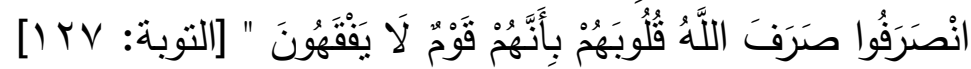
تتحدث هذه الآية الكريمة عن شيء من مخازي المنافقين؛ إذ إنه كلما نزلت لته

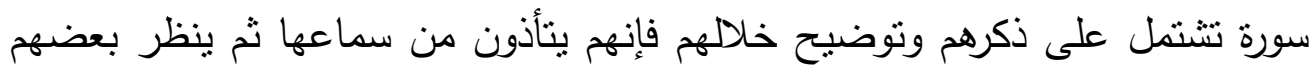
إلى بعض نظرا من لون خاص يدل على الطعن في تلكم السورة والاستخفاف بها وتحقير شأنها، وذكر البعض من المفسرين أنه يحتمل أن يكون استخفافه غير فاصر لفر فاصر

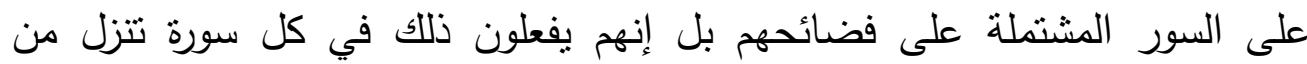
القرآن، وبمجرد سماعهم يقومون بالاستهزاء بها والطعن فيها والتغامز والتضاحلك فيما

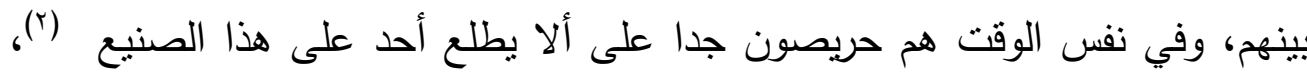
ولا شك أن هذا النظر والتخامز من قبيل إثارة الجسد.

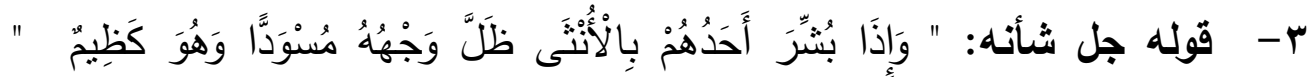
[النحل: O^]

تتحدث تلك الآية عن علامة ظاهرية من قبيل إثارة الجسد- وهي سواد الوجه- تدل على معاني مسنكنة في الباطن، وهي الغم والحزن الثديد بسبب إنجاب

( (1) فتح القدير : محمد بن علي الثوكاني، الناشر : دار ابن كثير - دمشق، ط: 1 - ع اع| هـ، ع| 001

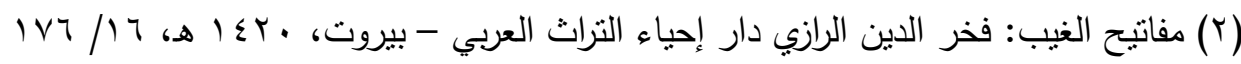


الإناث، فتعبيرات الوجه ترجمان لما بداخل صاحبه؛ فالإنسان إذا اعتراه فرح ينشرح

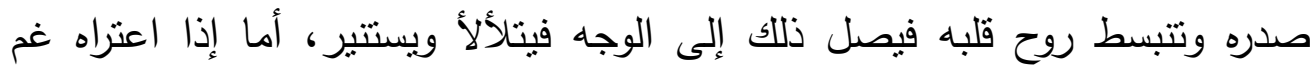
فتحتقن الروح في باطن القلب ولا يبقى أثز قوي منه في ظاهر الوجه فيعتري الوجه

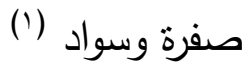

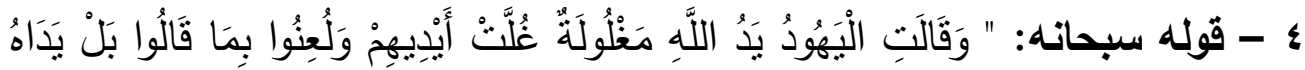

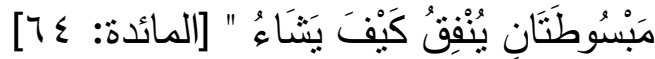
تتحدث تللك الآية عن وصف اليهود عليهم لعائن الله لله- سبحانه وتعالى -

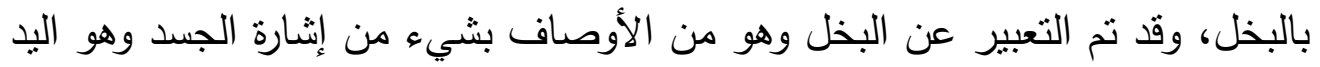

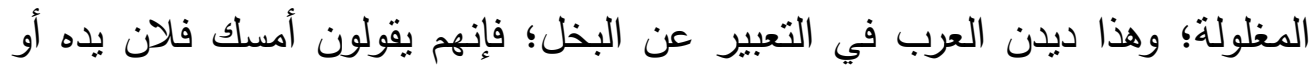

قبض يده، وحينما يعبرون عن الكرم والبذل بستعملون بسط البد دلالة على ذللك (r).

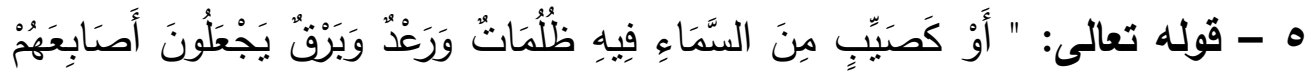

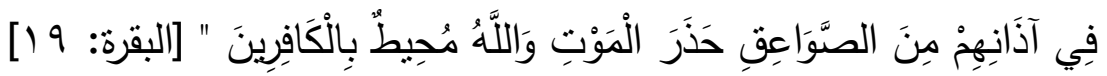

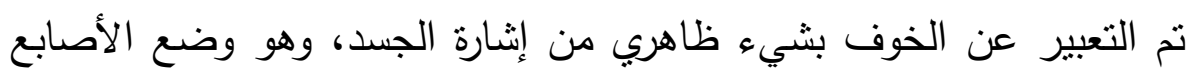
في الآذان، ولم تقل الآية يجعلون أناملهم، وإنما عبرت بالأصابع للألالة على على شدة

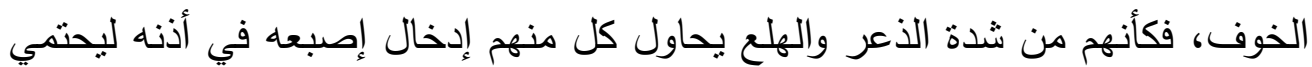

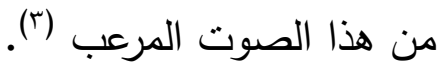
צ - قوله عز وجل: " قل كونوا حجارة أو حديدا، أو خلقا مما يكبر في صدوركم فسيقولون من يعيدنا قل الذي فطركم أول مرة فسينغضون إليك رعوسهم ويقولون منى

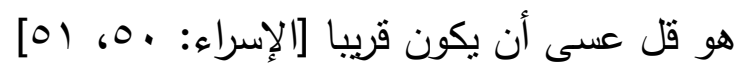

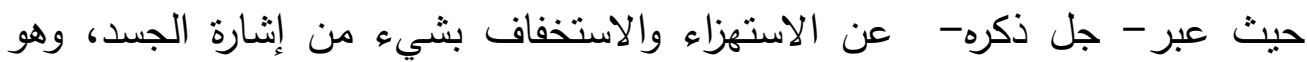

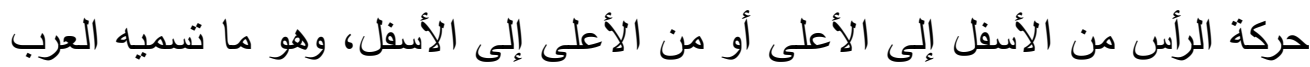

إنغاضا (£)

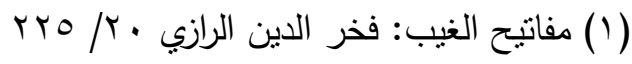

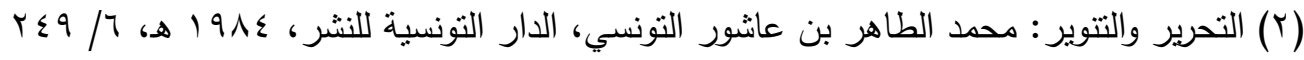

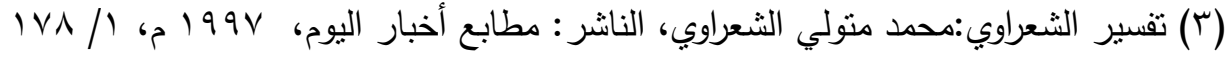

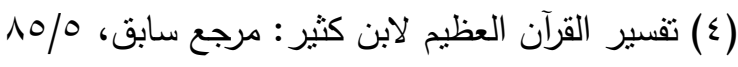




\section{المطلب الثالث}

\section{نماذج من إشارة الجسد في السنة المطهرة}

ورد في السنة النبوية المطهرة ما هو من قبيل إثنارة الجسد، وحسبنا من ذلك أمثلة نوردها فيما يلي: ا - عن طارق بن شهاب، قال: سمعت ابن مسعود، يقول: شهدت من المقداد بن الأسود مشهدا لأن أكون صاحبه أحب إلي مما عدل به، أنى النبي صلى الله عليه وسلم وهو يدعو على المشركين، فقال: لا نقول كما قال قوم موسى: اذهب أنت وربك فقاتلا، ولكنا نقاتل عن يمينك، وعن شمالك، وبين يديك وخلفك، فرأيت النبي

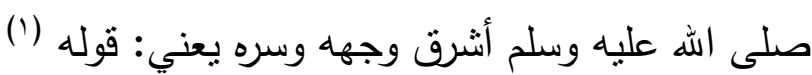

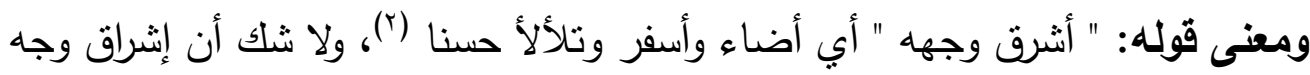
النبي - صلى الله عليه وسلم - دليل على حالة الفرح والسرور الكامن في النفس، فهي إثارة جسدية عن حالة نفسية كامنة بداخل الثخص. r - عن عائشة أنها قالت: إن رسول الله صلى الله عليه وسلم، دخل علي مسرورا، تبرق أسارير وجها، فقال: " ألم تري أن مجززا نظر آنفا إلى زيد بن حارثة، وأسامة

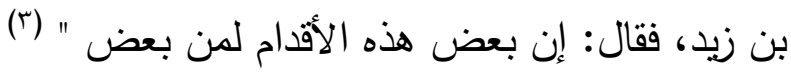
فالرجل القائف المدعو مجزا ألحق نسب أسامة بن زيد بأبيه زيد، وكانت الجاهلية تشكك في نسب أسامة؛ وذلك لكونه شديد السواد وزيد كان رجلا أبيضا، فلما رأى النبي- صلى اله عليه وسلم - ذلك فرح، وهذا الفرح المستكن في القلب أظهرته إنارة الجسد التي عاينتها السيدة عائثة بقولها تبرق أسارير وجهه، ومعناها إضاءة وإنارة الخطوط التي في جبهنه (؟) عابنها:

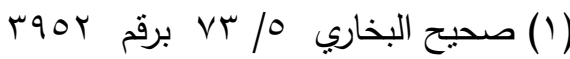

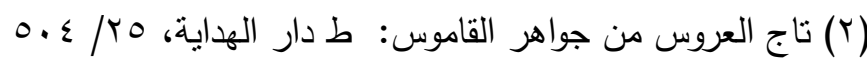

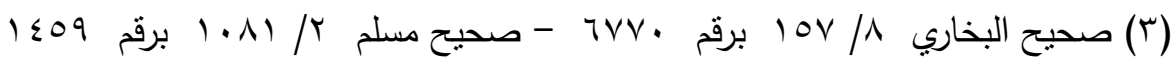

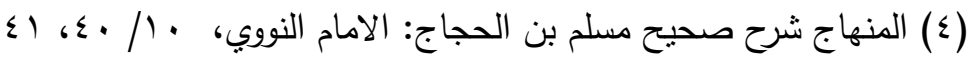


r- عن عائشة أم المؤمنين رضي الله عنها: أنها أخبرت أنها اشترت نمرقة فيها تصاوير، فلما رآها رسول الله صلى الله عليه وسلم قام على الباب فلم يدخله، فعرفت في وجهه الكراهية، فقلت: يا رسول الله أتوب إلى الله وإلى رسوله صلى الله عليه وسلم ماذا أذنبت؟ فقال رسول الله صلى الله عليه وسلم: 》 ما بال هذه النمرقة؟ هقت: اشتريتها للك لتقعد عليها وتوسدها، فقال رسول الله صلى الله عليه وسلم: "إن أصحاب هذه الصور يوم القيامة يعذبون، فيقال لهم أحيوا ما خلقتمه (')

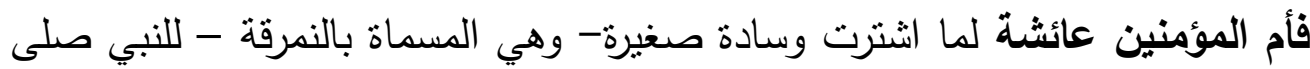
الله عليه وسلم لكي يتوسدها، وكان بها تصاوير قام على الباب كارها لتلك الوسادة(r)،

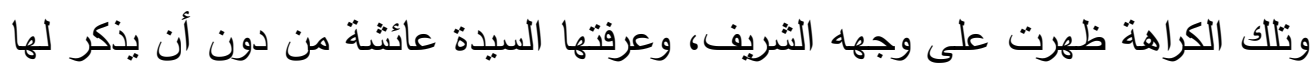
النبي تللك الكراهية، مما يدل على اعتمادها على إثنارة الجسد. ـ - عن زينب بنت جحش زوج النبي صلى الله عليه وسلم، قالت: خرج رسول الله صلى الله عليه وسلم يوما فزعا محمرا وجهه، يقول: 》لا إله إلا الله ويل للعرب من شر قد اقترب، فتح اليوم من ردم يأجوج ومأجوج مثل هذه《 وحلق بإصبعه الإبهام، والتي تليها، قالت فقلت: يا رسول الله أنهلك وفينا الصالحون؟ قال: لانعم إذا كثر

(r) الخبث:

تصف لنا السيدة زينب حالة الفزع التي اعترت النبي لما فتح مقدار حلقة من ردم

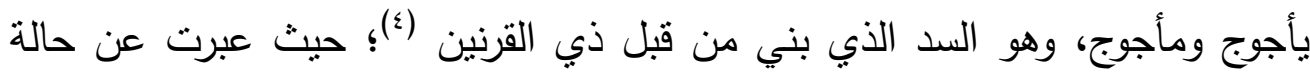
الفزع بما رأته ظاهرا على جسده الثريف وهو وهو حمرة الوجه.

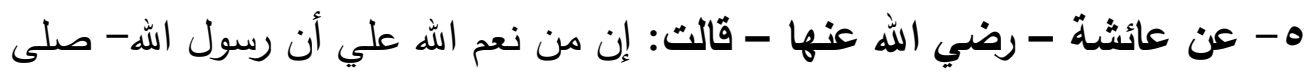
الله عليه وسلم- توفي في بيتي، وفي يومي، وبين سحري ونحري، وأن الله جمع بين

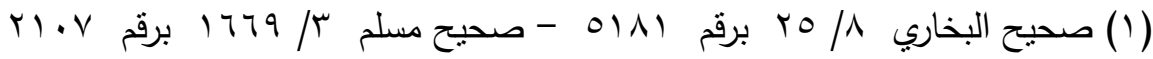
(Y) عمدة القاري شرح صحيح البخاري: أبو محمد محمود بن أحمد بن موسى بن أحمد أحمد بن حسين

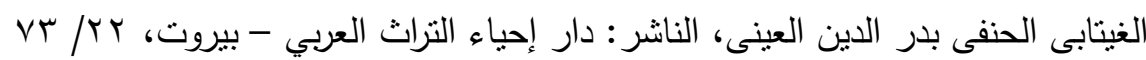

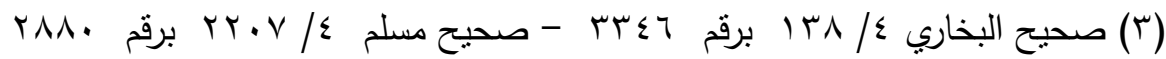

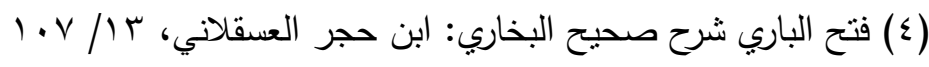


ريقي وريقه عند موته: دخل علي عبد الرحمن، وبيده السواك، وأنا مسندة رسول الله صلى الله عليه وسلم، فرأيته ينظر إليه، وعرفت أنه يحب السواك، فقلت: آخذه للك؟

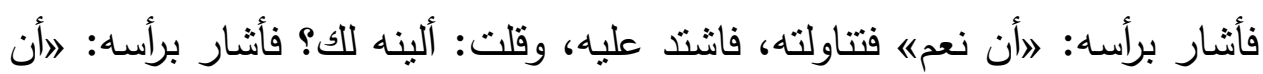
نعمه فلينته، فأمره، وبين يديه ركوة أو علبة فيها ماء، فجعل يدخل يديه في الماء فيمسح بهما وجها، يقول: 》لا إله إلا الله، إن للموت سكراته ثم نصب يده، فجعل

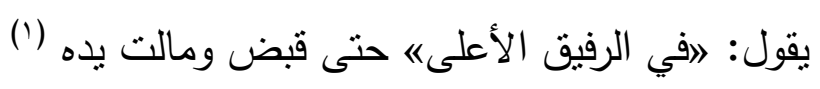

فالسيدة عائشة لما رأت النبي ينظر إلى السواك عرفت من نظراته رغبته في الاستياك في تلكم اللحظة؛ فقالت له آخذه للك فأثنار برأسه بالموافقة فأعطته السواك، فاشتثا عليه فقالت له ألبنه للك أي أمضغه بأسناني فأشار بالموافقة فمضغته له حتى صيرته لينا(؟)، وهي في كل ما سبق تعتمد على نظراته وإشاراته، وما ذللك إلا إثارة الجسد.

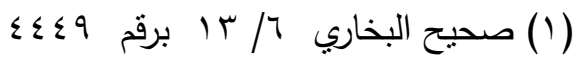

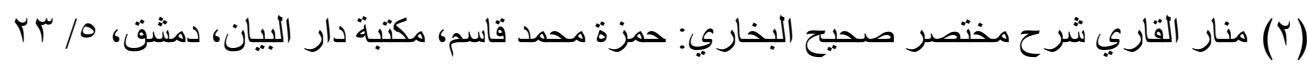




\section{المبحث الثاني \\ دليل التيسير ورفع الحرج عن المكلفين وضابطه}

لتجلية هذا الأمر سأبدأ بذكر الأدلة على التيسير ورفع الحرج عن المكلفين في

مطلب أول، ثم في المطلب الثاني بحول الله وقوته أتكلم عن ضوابط التيسير • المطلب الأول : الأدلة على التيسير ورفع الحرج عن المكلفين

إن التيسير على المكلفين ورفع الحرج عنهم من المقاصد الأساسية في الثريعة الإسلامية؛ وذللك لأن نصوص الثريعة الإسلامية وقواعدها شاهدة على نفي العسر والمشقة عن المكلفين، فليس الغرض من التكاليف الثرعية إلا مصلحة المكلفين وتحقيق النفع لهم، وما أجمل ما قاله ابن القيم: " والهه سبحانه إنما سمى أوامره ونواهيه عهذا ووصية ورحمة وموعظة، ولم يطلق عليها اسم التكليف إلا في مقام النفي كقوله:

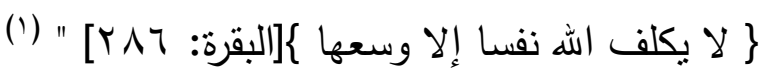

ولذلك فإن كل ما بترتب عليه مشقة زائدة أو غير معتادة مما بفضي إلى إلى

الضيق والعسر في الأبدان كالآلام والأمراض الحسية أو في النفس كالآلام المعنوية والنفسية أو في المال كالتلف والضياع والخسارة فإن الثريعة الإسلامية بسماحتها ترفعه أو تخففه بالكف عن الفعل الموقع في الحرج تارة وبإباحة الفعل عند الحاجة إليه نارة

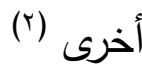

وقد دل على هذا التيسير ورفع الحرج عن المكلفين أدلة كثيرة نذكر بعضا منها فيما يلي:

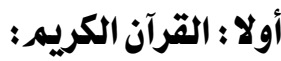
ا - قوله تعالى: "وما جعل عليكم في الدين من حرج " [الحج: VA].

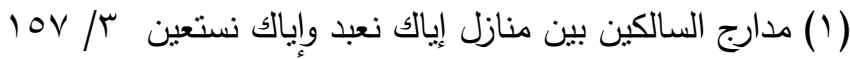

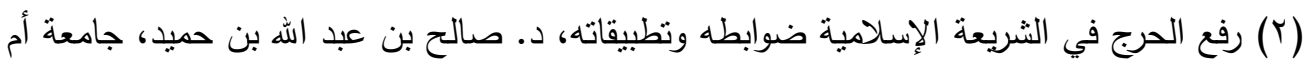

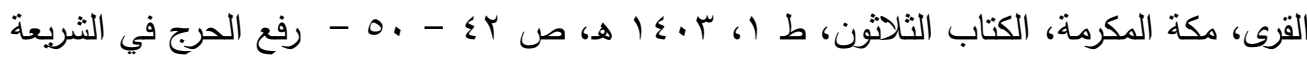

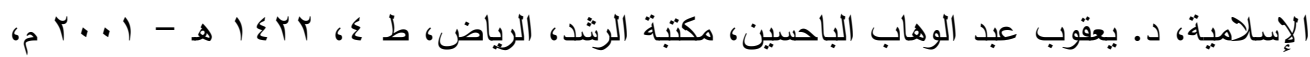

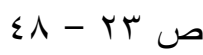


إشارة الجسل من مظاهر التيسير ورفع الحرج في الفقه الإسلامي

د/حليمرجب كامل السيد

ץ - قوله تعالى: " ما يريد الله ليجعل عليكم من حرج " [المائدة: 7]].

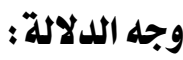

ان الله تعالى نفى في هاتين الآيتين الحرج عن الأمة والإثم الأخروي وكذا الضيق الدنيوي، ولفظة الحرج أتت نكرة بعد نفي للالالة على عموم النفي وعدم النى

اختصاصها بأمر دون غيره (1)

r- قوله تعالى: " ليس على الضعفاء ولا على المرضى ولا على الذين لا يجدون ما دئ ينفقون حرج إذا نصحوا لله ورسوله " [التوبة: 19

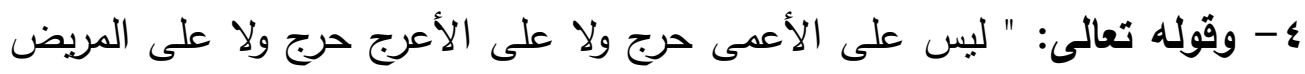

حرج " [النور : 17 (7)

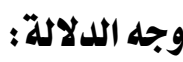

إن هاتين الآيتين قررتا نفي الحرج ورفعه؛ وذللك بإسقاط التكليف عن

الموصوفين في الآيتين؛ وذلك لعجزهم من الناحية المالية أو البدنية؛ فالأعمى رفع عنه

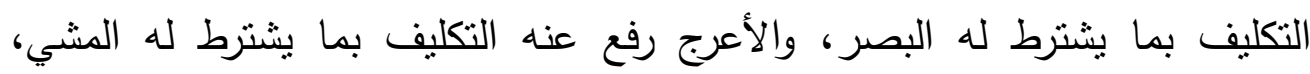

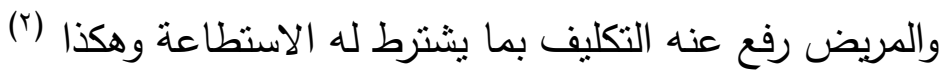

ثانيا : السنة المطهرة:

ا- عن ابن عباس قال: قيل لرسول الله- صلى الله عليه وسلم-: أي الأديان أحب

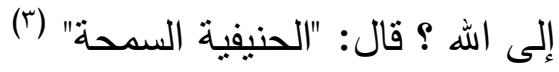

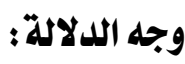

أن معنى قوله الحنيفية السمحة: أي الشريعة المائلة عن كل دين باطل إلى

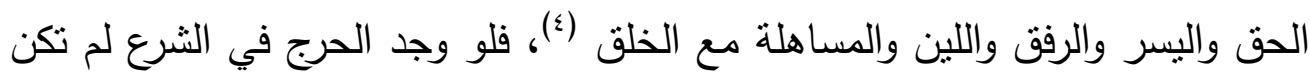

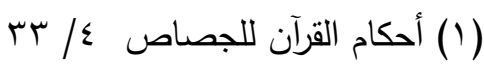

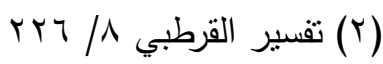

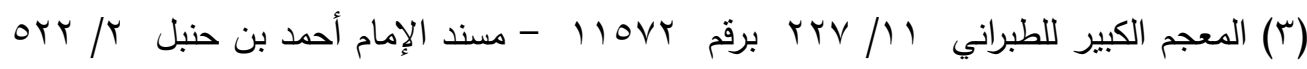

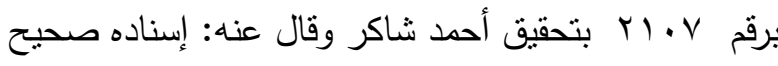

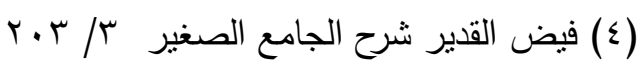


الثريعة موصوفة بأنها سمحة، بل كانت حرجة ضيقة وهو باطل؛ لمنافاته للحديث النبوي الثريف فبطل ما أدى إليه. r - عن أسامة بن شريك قال: شهدت الأعراب يسألون النبي صلى الله عليه وسلم: أعلينا حرج في كذا؟ أعلينا حرج في كذا؟ فقال لهم: لاعباد اله، وضع الله الحرج، إلا

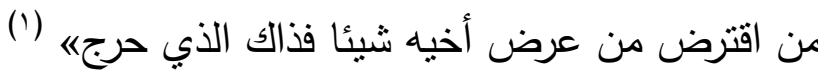
r - عن عروة الققيمي قال جعل الناس يسألونه صلى الله عليه وسلم يا رسول الله،

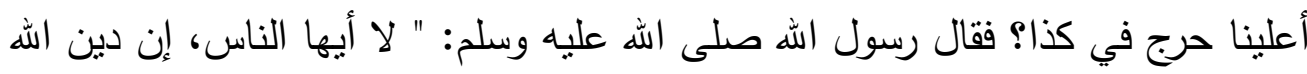

في بسر " ثنلاثنا يقولها (r)

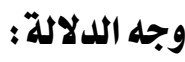
دل هذان الحديثان بطريقة واضحة على أن رفع الحرج أمر ثابت مقرر في الثريعة الإسلامية كما ورد في الحديث الأول، وأن اليسر هو سمة من سمات هذات الدين الحنيف كما جاء في الحديث الثاني. ثالثا : الإجماع: فقد استقر أنه لا حرج في شرع الله وأحكامه من لدن صحابة النبي صلى الله عليه وسلم في فتاويهم وأحكامهم حتى يوم الناس هذا، ولا يعلم في ذلك مخالف فكان ذللك إجماعا عليه (r)

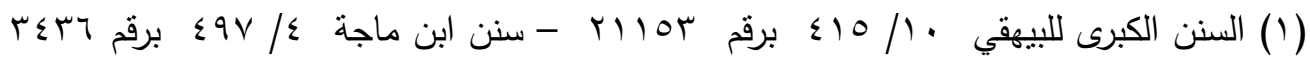

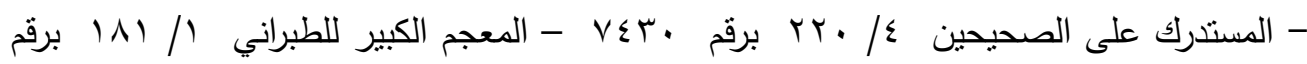

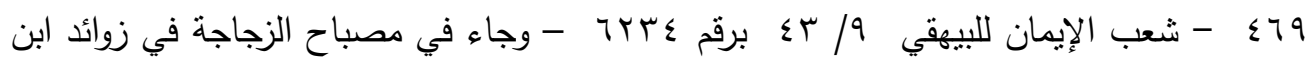

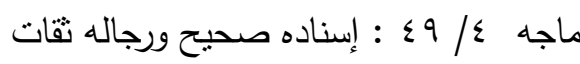

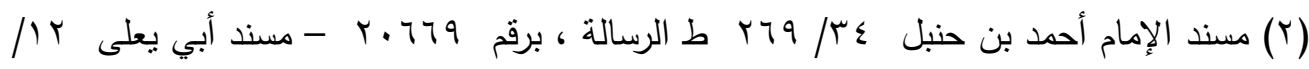

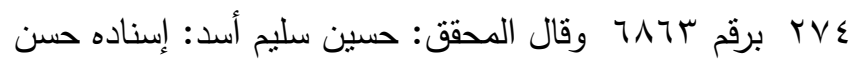

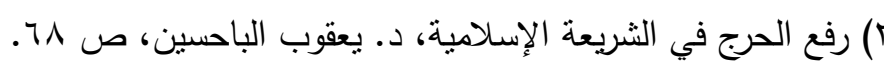




\section{رابعا : المققول :}

ا- أن الحرج إن لم يكن منفيا في الثرع لكان ثابتا، لكن ثثوته باطل فبطل ما أدى إليه وصدق نقيضه من كون الحرج منفيا في الثرع، وهذا ثابت باستقراء الأحكام الشرعية استقراء تاما فليس فيها من حرج، وما يظنه البعض حرجا في الشرع فهو على التحقيق ليس بالحرج؛ إذ هو موضوع لرفع حرج أعظم منه (').

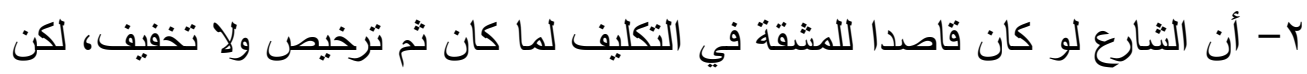

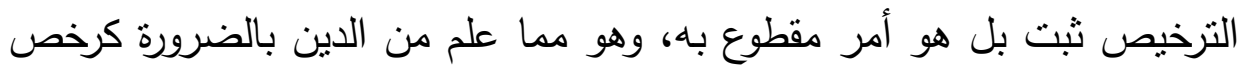
الفطر والجمع والقصر وتتاول المحرم في الاضطرار، وهذا يدل على عدم قصد

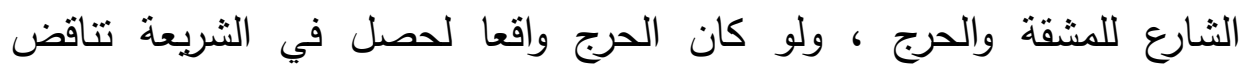
واختلاف، وذلك منفي عنها؛ فإنه إذا كان وضع الثريعة على قصد المشقة والإعنات-وقد ثبت أنها موضوعة على قصد التيسبر والرفق - كان الجمع بينهما تتاقضا واختلافا، وهي منزهة عن ذللك (r)

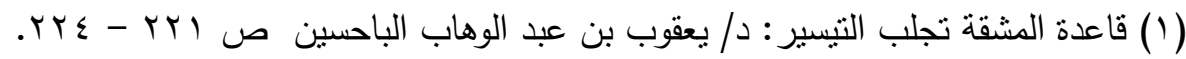

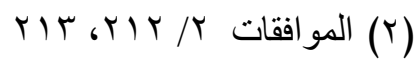




\section{المطلب الثاني \\ ضوابط التيسير}

لا بد من توافر عدة ضوابط في تطبيق مبدأ التيسير ورفع الحرج عن المكلفين، وبيانها كالتالي:

\section{الضابط الأول : وجود ما يلدو إلى التيسير :}

فحتى لا يكون التيسير ذريعة لمجاراة الأهواء أو العبث في الدين فلا بد من

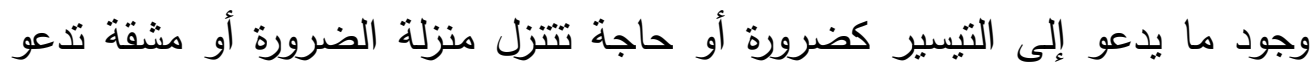
للتيسير، فليس كل مشقة تعرض للمكلف تستدعي التيسير، فإن المشقة لا ينفك عنها أي عمل من الأعمال غالبا؛ فمشقة الوضوء والغسل في شدة البرد ، ومشقة إقامة الصلاة في الحر والبرد، ولا سيما صلاة الفجر، ومشقة الصيام في شدة الحر وطول الهال النهار كل هذه المشاق لا أثر لها في إسقاط العبادات والطاعات ولا في تخفيفها. ولكن المشقة التي تدعو للتيسير فهي المشقة التي تتفك عنها التكاليف غالبا، وهي أنواع: النوع الأول: مشقة عظيمة فادحة كشقة الخوف على النفوس والأطراف ومنافع الأطراف، فهذه مشقة موجبة للتخفيف والترخيص. النوع الثاني: مشقة خفيفة كأدنى وجع في إصبع أو أدنى صداع أو سوء مزاج خفيف، فهذا لا التقات إليه ولا تعريج عليه. النوع الثالث: مشاق واقعة بين هاتين المشقتين مختلفة في الخفة والثدة، فما دنا منها من المشقة العليا أوجب التخفيف، وما دنا منها من المشقة الدنيا لم يوجب التخفيف"(()

\section{الضابط الثاني : ألا يترتب على التيسير مصادمة الشريعة :}

وفي ذلك يوضح القرافي - رحمه الله- أن كل شيء أفنى فيه المجتهد وكانت

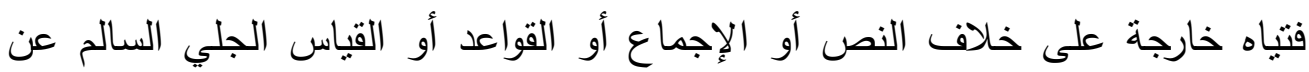
(1) قواعد الأحكام r/ 9، ـ 1 - الرخص الثرعية أحكامها وضوابطها، د. وهبة الزحيلي، دار

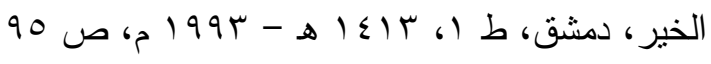


المعارض الراجح فإنه لا يجوز لمقلده أن ينقله للناس، ولا أن يفتي به في دين الله

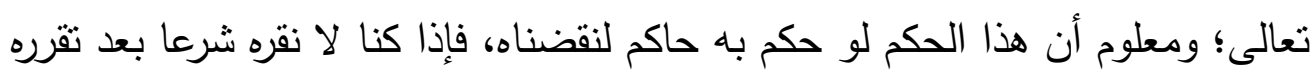
بحكم الحاكم فأولى بنا ألا نقره شرعا إذا لم يتأكد، وهذا لم يتأكد فلا نقره شرعا، والفتيا

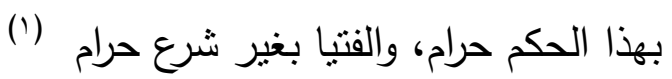

\section{الضابط الثالث: ألا يترتب على التيسير مفسلة في المآل :}

فيجب على المفتي مراعاة مآلات الأمور وأن يعمل مبدأ سد الذرائع، وأن

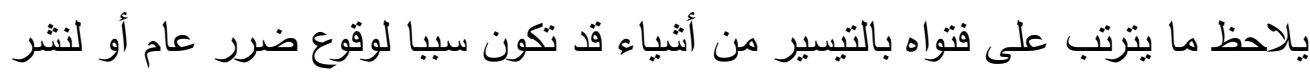
فتتة بين الناس حتى وإن كان رأيه رأيا شرعيا. وقد ذكر شيخ الإسلام ابن تيمية: أنه لو تحاكم إلى الحاكم والعالم شخص من لن إنه المنافقين الذين يتخيرون بين قبول ما جاء في الكتاب والسنة وبين ترك ذلك، فإنه لا لا لإنه يجب عليه الحكم بينهم، وكذلك الثخص الذي لا يكون قصده من الاستفتاء الوصول

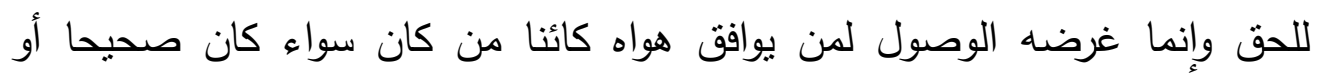
باطلا، فليس على خلفاء رسول الله أن يفتوه ويحكما لله فإن الله إنما بعث رسوله

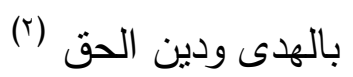

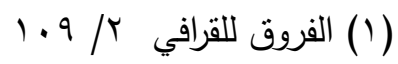

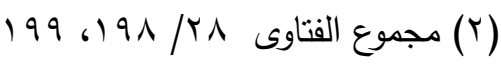




\section{المبحث الثالث}

\section{موقف الفقهاء من الاعتداد بـإشارة الجسل في مجال العبادات}

حتى نتمكن من تجلية التيسير ورفع الحرج عن المكلفين في مجال العبادات عن طريق إثنارة الجسد قمت بذكر أنموذجين من العبادات يحرم فيهما الكلام لنرى لنيه مدى اعتداد الفقهاء بإنشارة الجسد كأمر مباح يجلب التيسير ويرفع الحرج، وكل واحد بند من الأنموذجين في مطلب مستقل، فالمطلب الأول ذكرت فيه إعمال إثارة الجسد أثناء الصلاة، وفي المطلب الثاني ذكرت إعمال إثنارة الجسد أثناء خطبة الجمعة. 


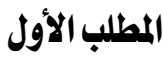 \\ إعمال إشارة الجسل أثناء الصلاة}

في البداية نقول: إن حرمة الكلام أثناء الصلاة وبطلانها بالكلام أمر اتفق

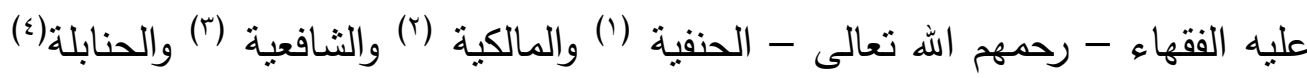

والظاهرية (0) والزيدية (؟).

واستدلوا بما يلي:

- عن معاوية بن الحكم السلمي، قال: بينا أنا أصلي مع رسول الله صلى الله عليه وسلم، إذ عطس رجل من القوم، فقلت: يرحمك الله فرماني القوم بأبصارهم، فقلت: وانكل أمياه، ما شأنكم؟ تتظرون إلي، فجعلوا يضربون بأيديهم على أفخاذهم، فلما رأيتهم يصمتونني لكني سكت، فلما صلى رسول الله صلى الله عليه وسلم، فبأبي هو وأمي، ما رأيت معلما قبله ولا بعده أحسن تعليما منه، فوالله، ما كهرني ولا لاله لهاله

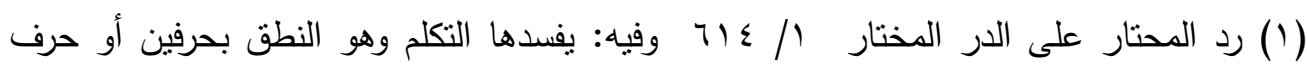

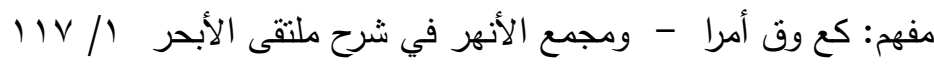

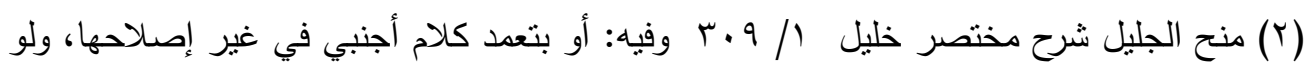

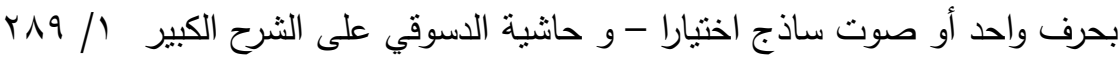

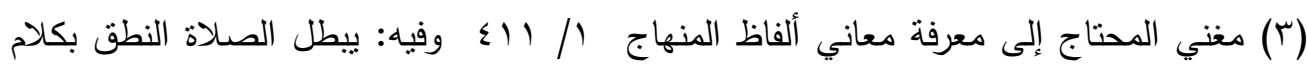

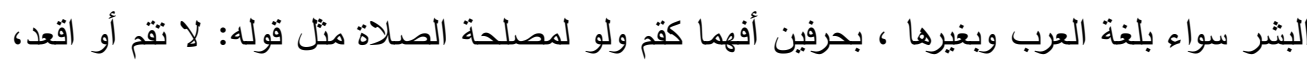

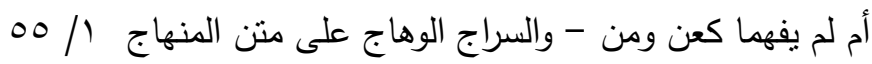

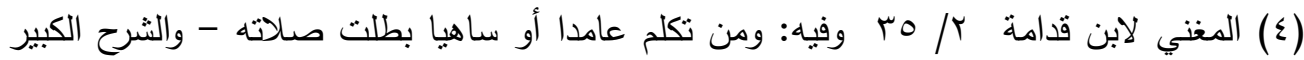

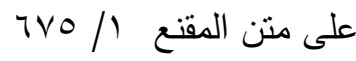

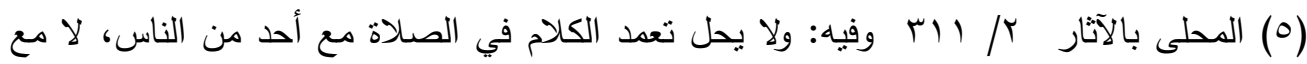

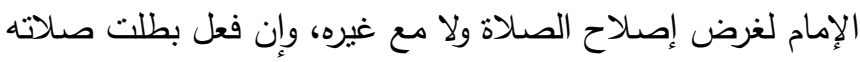

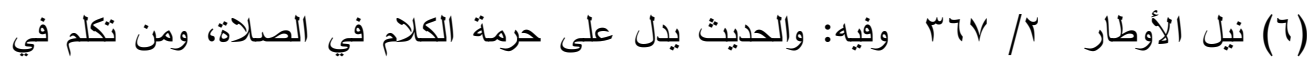

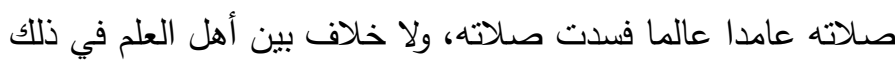


ضربني ولا شنتي، قال: " إن هذه الصلاة لا يصلح فيها شيء من كلام الناس،

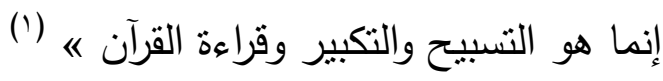

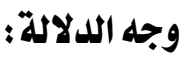

جعل صلى الله عليه وسلم عدم الكلام في الصلاة من حقها كوجود الطهارة فيها تماما،

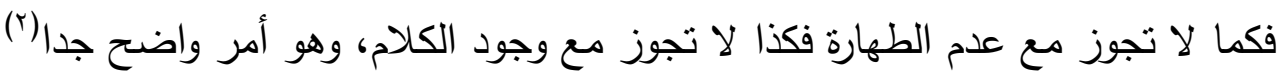
r - عن زيد بن أرقم، قال: " كنا نتكلم في الصلاة بكلم الرجل صاحبه وهو إلى جنبه

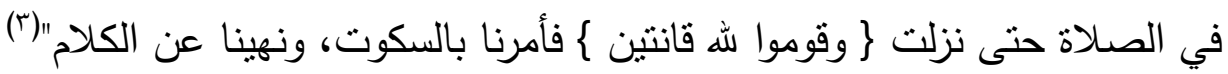

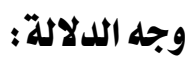

حيث دل هذا الحديث على الأمر بالسكوت في الصلاة والنهي عن الكلام؛ فلم

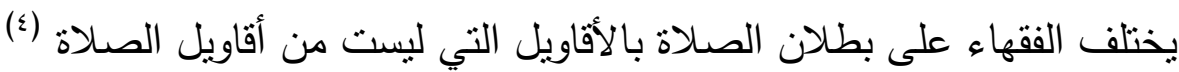
وأما عن مدى جواز استعمال إثارة الجسد في الصلاة فسنتحدث عنه في المسائل

الآتية:

\section{المسألة الأولى : إعمال إشارة الجسل لرد السلام من المصلي.}

إذا ألقى أحد الأشخاص السلام على المصلي فهل يجوز له أن يرد بالإشارة

بشيء من جسده اختلف الفقهاء - رحمهم الله تعالى - في ذللك على أقوال:

القول الأول: القول بجواز الرد بالإشارة أثناء الصلاة، ومن ثم لا يؤثز على الصلاة ولاهي تبطل.

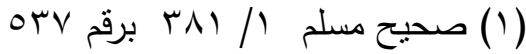

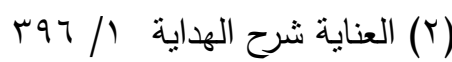

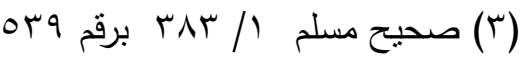

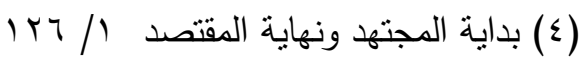


قال بهذا القول المالكية (') والثافعية (r) والحنابلة (r) والظاهرية (ع). القول الثاني: القول بكراهة رد السلام بالإثارة أثثاء الصلاة. وهذا هو قول الحنفية(ه). القول الثالث: القول بوجوب الرد بالإشارة من المصلي: وهو مذهب الزبدية (؟) وقول عند المالكية (v)

(1) مواهب الجليل //09؛ - شرح مختصر خليل للخرشي 1/ • بr وفيه: وأبيح له الرد إثشارة في الصلاة

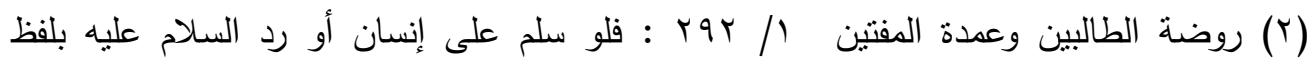
الخطاب فقد بطلت صلاته. ويرد السلام بالإشارة بيده أو رأسه - أسنى المطالب في شرح روض

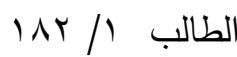

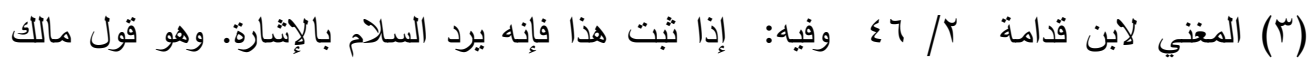

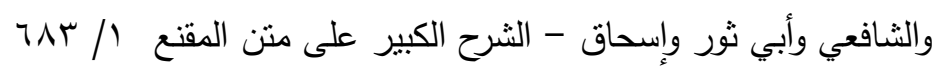

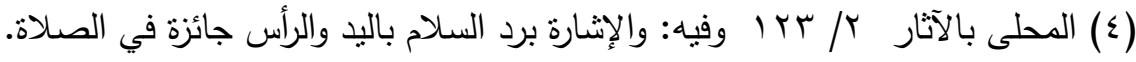

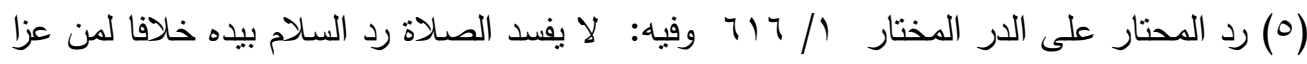
إلى أبي حنيفة أنه يفسد، فإنه لم يعرف نقله من أحد من أهل المذهب... والحق أن الفساد ليس بثابت

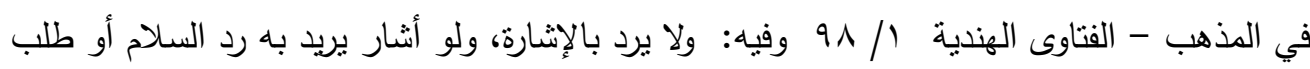

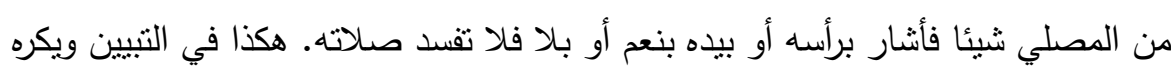

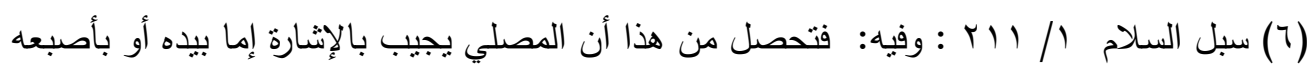
أو برأسه، والظاهر أنه واجب.

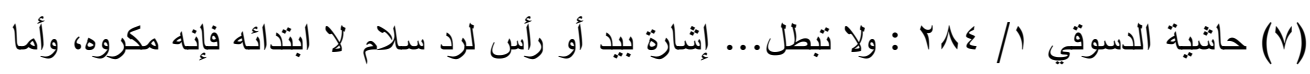
رده باللفظ فمبطل، والراجح أن الإشارة للرد واجبة - منح الجليل // r.r : والراجح أن الإشارة لرده 
أدلة الاققوال:

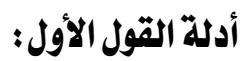

استدل أصحاب القول الأول على جواز الرد بالإثارة أثناء الصلاة، وعدم تأثثر ذلك عليها بالبطلان بما يلي:

من السنة: ا - عن عائشة قالت: " اثتكى رسول الله صلى الله عليه وسلم فخل عليه ناس من

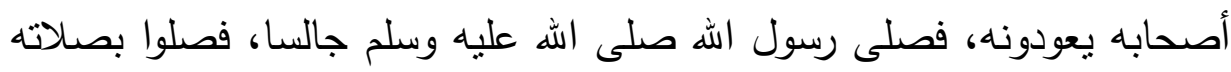

قياما فأشار إليهم: أن اجلسوا فجلسوانها " (1)

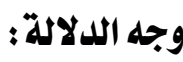

إن هذا الحديث يدل على جواز رد المصلي السلام بالإثارة؛ لأنه صلى الله

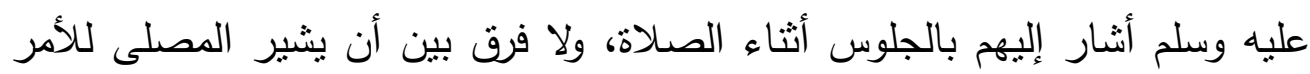

بالجلوس وبين أن يشير للإخبار برد السلام (؟). r- عن جابر أنه قال: إن رسول الله صلى الله عليه وسلم بعثني لحاجة، ثم أدركته وهو يصلي فسلمت عليه، فأنشار إلي، فلما فرغ دعاني فقال: اإنك سلمت آنفا وأنا

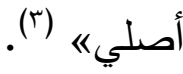
r- عن ابن عمر، قال: قلت لبلال: كيف كان النبي صلى الله عليه وسلم يرد عليهم حين كانوا بسلمون عليه وهو في الصلاة؟ قال: كان يشير بيده (ء). ـ - عن صهيب، قال: مررت برسول الله صلى الله عليه وسلم وهو يصلي، فسلمت

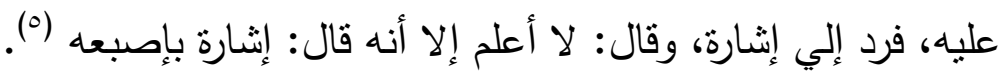

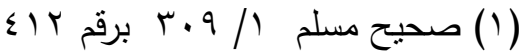

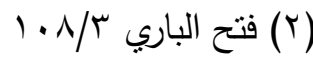

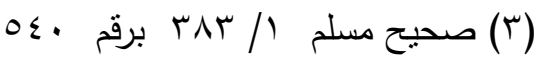

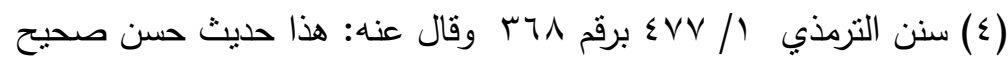

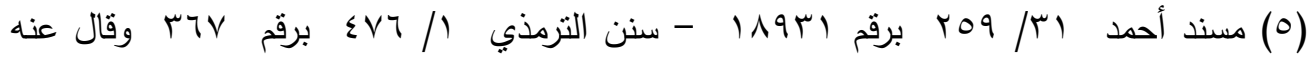

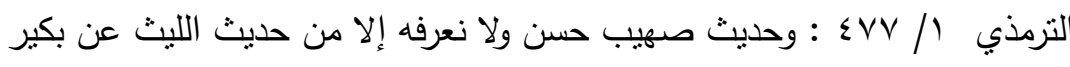




\section{وجه الدلالة:}

دلت هذه الأحاديث على جواز أن يسلم غير المصلي على المصلي، وعلى جواز الرد بالإشارة أثثاء الصلاة؛ لأن المصلي ممنوع من الكلام فليس أمامه إن أراد رد السلام إلا

(1) أن بشير

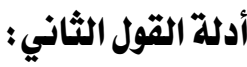

استدل أصحاب القول الثاني على القول بكراهة رد السلام بالإشارة أنثاء الصلاة بما يلي:

من السنة:

ا - عن عبد الله، قال: كنا نسلم على رسول الله صلى الله عليه وسلم وهو في الصلاة، فيرد علينا، فلما رجعنا من عند النجاثي، سلمنا عليه فلم يرد علينا، فقلنا: يا رسول الله كنا نسلم عليك في الصلاة فترد علينا، فقال: 》إن في الصلاة شغلاه

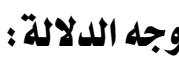

دل هذا الحديث على أنه بسبب الانشغال في الصلاة لا ينبغي للشخص أن يسلم على المصلي ولا للمصلي أن يرد سلامه بإثارة ولا غير ذلك؛ لأن إلقاء السلام يشغل قلب المصلي عن صلاته فيصير مانعا له عن الخير، وأما رد السلام بالقول فلأن رد السلام من جملة كلام الناس، وإذا رد بالقول فسدت صلاته؛ ولو رد بالإثارة لا تفسد؛ لأن ترك سنة كف اليد لا يفسد الصلاة ولكن بوجب الكراهة (؟).

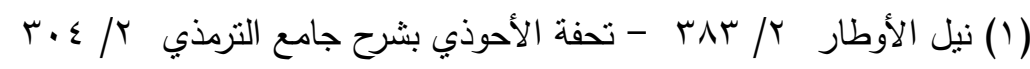

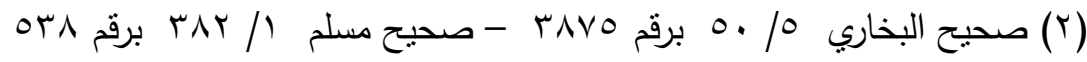

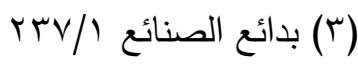




\section{ونوقش الاستدلال بهذا الدليل:}

بأنه ينبغي علينا أن نحمل قوله: " فلم يرد علينا " على الرد بالكلام وليس

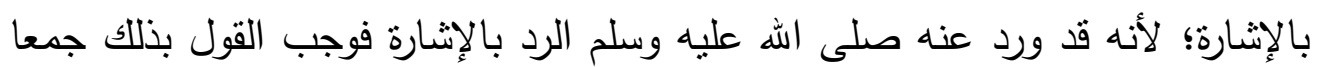

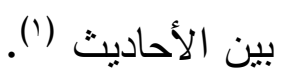

r - عن جابر بن عبد الله- رضي الله عنهما- قال: بعثني رسول الله صلى الله عليه وسلم في حاجة له، فانطلقت، ثم رجعت وقد قضيتها، فأتيت النبي صلى الله عليه وسلم، فسلمت عليه، فلم يرد علي، فوقع في قلبي ما اله أعلم به، فقلت في نفسي: لعل رسول الله صلى الله عليه وسلم وجد علي أني أبطأت عليه، ثم سلمت عليه فلم يرد علي، فوقع في قلبي أثند من المرة الأولى، ثم سلمت عليه فرد علي، فقال:

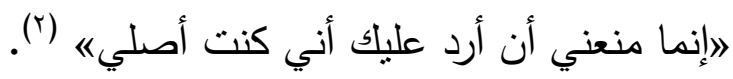

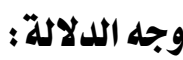

هذا الحديث دليل على أن المصلي لا يرد السلام باللسان ولا بالإشارة؛ أما

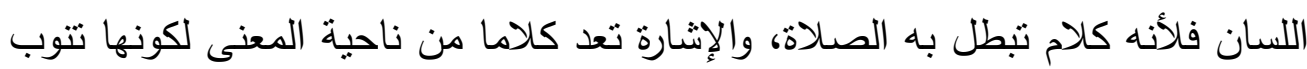

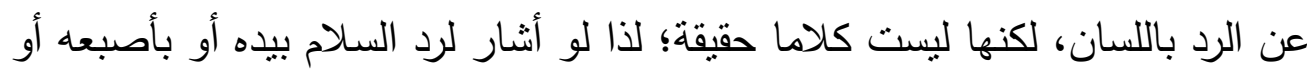

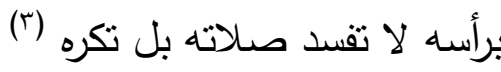
ونوقش الاستدلال بهذا الدليل: بأنه قد ورد في بعض روايات الحديث: " فقال لي بيده هكذا " وفي رواية أخرى

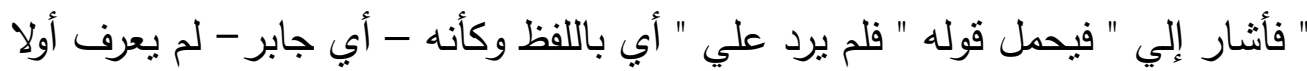
أن المراد بالإنشارة الرد عليه؛ فلذلك وقع في قلبه الحزن؛ لأن النبي صلى اله عليه وسلم بله بله

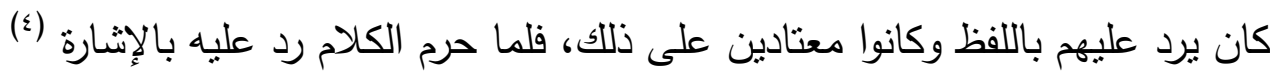

$$
\begin{aligned}
& \text { (1) نيل الأوطار بر rم }
\end{aligned}
$$

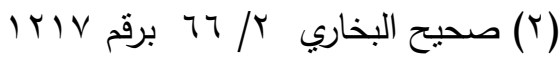

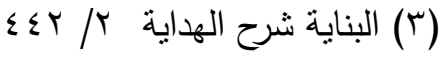

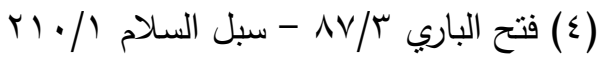


ץ- عن جابر بن سمرة، قال: خرج علينا رسول الله صلى الله عليه وسلم فقال: 》 ما لي أراكم رافعي أيديكم كأنها أذناب خيل شمس؟ اسكنوا في الصلاة ه (')

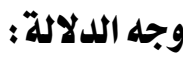

في هذا الحديث أمر من النبي الله صلى الله عليه وسلم بالسكون في الصلاة، ومعلوم أن رد السلام بالإشارة يعد منافيا لهذا السكون؛ لأن فيه رفع اليد وتحريك بله

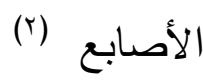

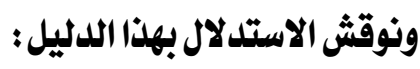

أن المراد بالرفع المنهي عنه في هذا الحديث هو رفعهم أيديهم عند السلام مشيرين إلى السلام من الجانبين فنهاهم عن ذللك، وشبه تلاك الفعلة بتحرك أذناب الخيل الثمس - بإسكان الميم وضمها- وهي التي لا تستقر بل تضطرب وتتحرك بأذنابها وأرجلها، فليس للحديث علاقة برد السلام بالإشارة (). ع - عن أبي هريرة - رضي الله عنه - عن النبي- صلى الله عليه وسلم - قال: "لا غرار في صلاة ولا تسليم" (๕).

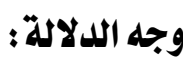

دل هذا الحديث على أن الصلاة لا يكون فيها نقص ولا تسليم ؛ لأن الغرار في الصلاة

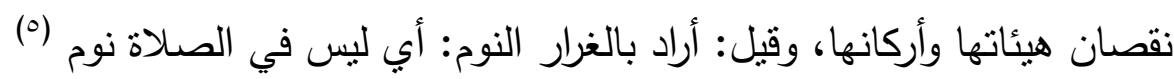

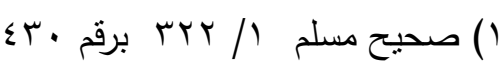

$$
\begin{aligned}
& \text { ش ش }
\end{aligned}
$$

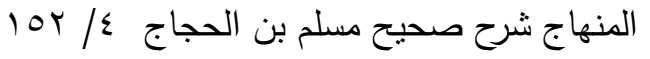

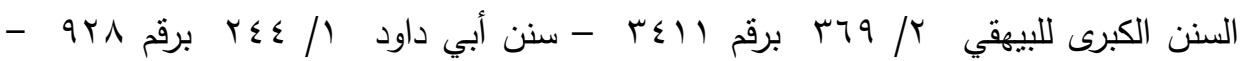

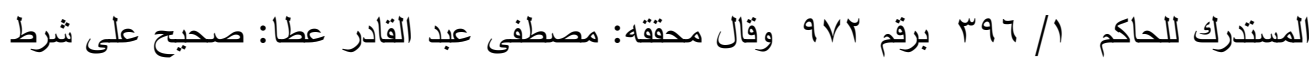

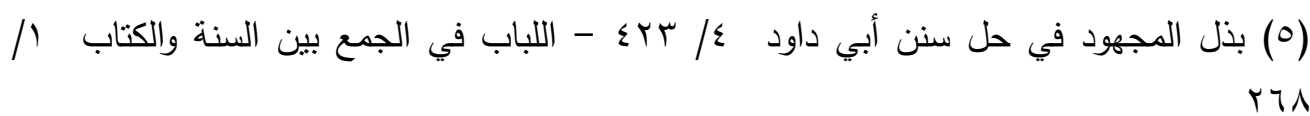




\section{ونوقش الاستدلال بهذا الحديث:}

بأنه لا بدل على المطلوب من عدم جواز رد السلام بالإشارة؛ لأنه ظاهر في التسليم على المصلي لا في الرد منه، ولو سلم شموله للرد لكان الواجب حمل ذلك على الرد باللفظ جمعا بين الأحاديث ('). أدلة القول الثالث: - الث استدل أصحاب القول الثالث على القول بوجوب رد السلام بالإشارة من المصلي بما يلي:

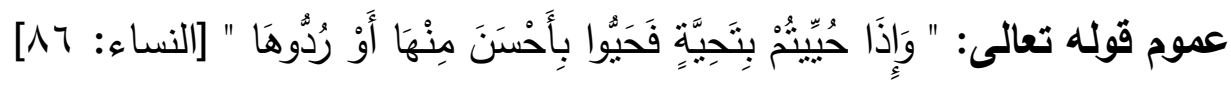

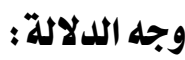

دلت هذه الآية الكريمة على أن رد السلام بالقول واجب، وقد تعذر في الصلاة الرد

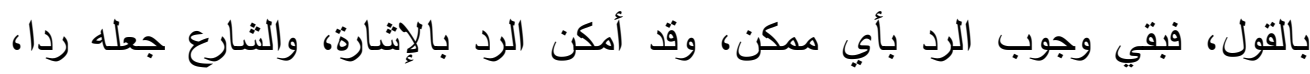
والصحابة سموه ردا، فتدخل الإثارة تحت قوله تعالى

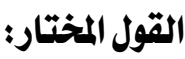

بعد ذكر آراء الفقهاء وأدلتهم والمناقثنات الواردة من بعضهم على بعض تميل

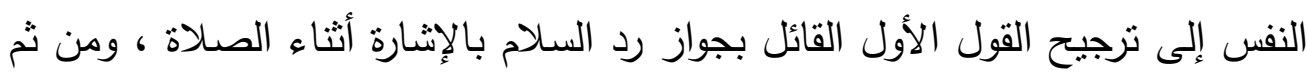

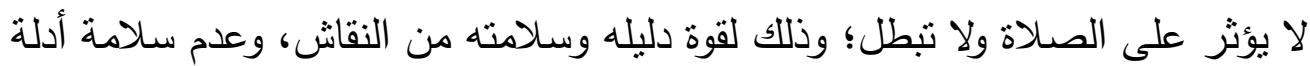

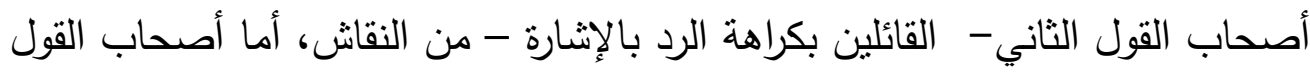

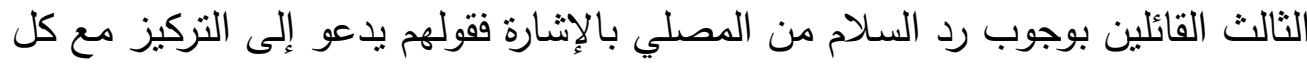

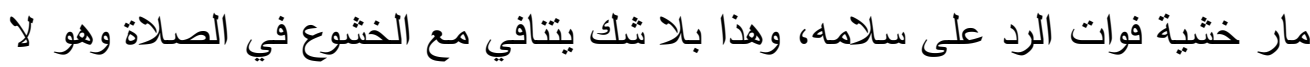

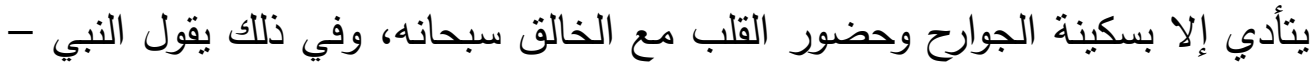

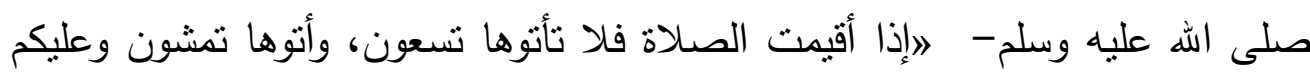

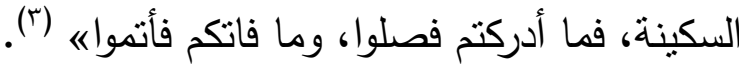

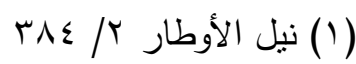

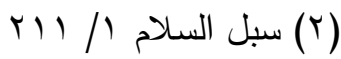

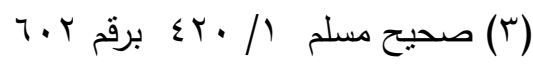


فأمر بعدم الإفراط في السعي لأنه إذا قدم على الصلاة بعد شدة السعي يكون عنده قلق

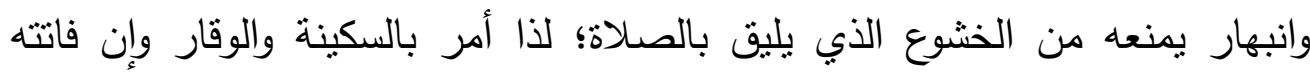

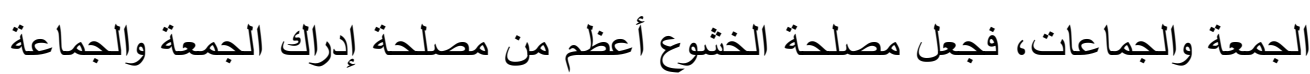

مع أن الجمعة واجبة (1) فكيف بتقديم رد السلام على الخشوع !!! وأما عن كيفية الرد بالإشارة أثناء الصلاة فقد ورد في كيفية الإشارة لرد السلام في الصلاة أحاديث كثيرة، وكل حديث ذكر هيئة معينة للإشارة لرد السلام، فبعض الروايات ذكرت أنه صلى الله عليه وسلم

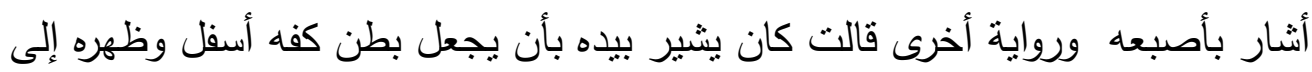

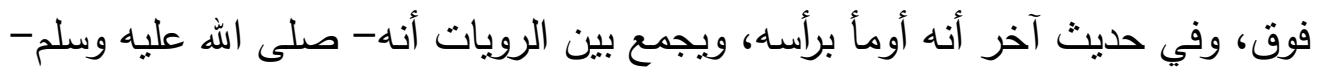
فعل هذا مرة وهذا مرة، فيكون جميع ذلك جائزا.

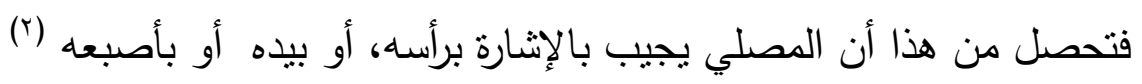

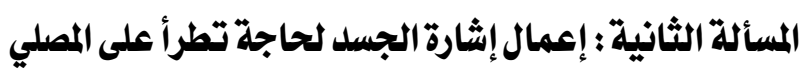
إذا عرض للإنسان شيء وهو في صلاته، واحتاج إلى أن يشير إنثارة تفهم عنه، فما حكم ذللك؟. اختلف فقهاؤنا في ذلك على قولين: القول الأول: أن الإشارة في الصلاة لأمر ينزل فيها أو لحاجة تطرأ على المصلي فولي

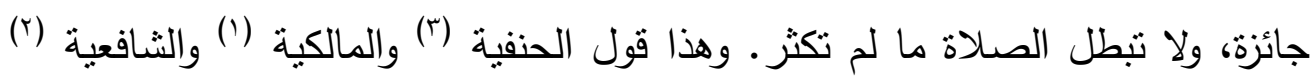

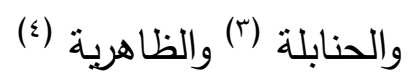

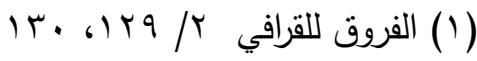

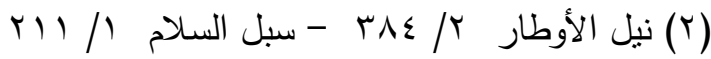

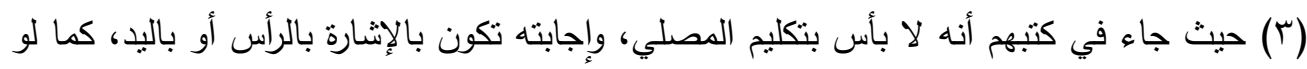

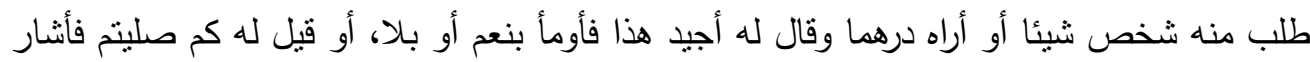
له بيده أنهم قد صلوا ركعتين 
القول الثاني: أن الإثارة في الصلاة لأمر ينزل فيها أو لحاجة تعرض للمصلى تفسد الصلاة.

وهذا قول نسبه الطحاوي لقوم لم يسمهم (0)، ونسبه زين الدين العراقي للحنفية (؟)

وأوردوا أيضا: أن من مبطلات الصلاة العمل الكثير الذي لبس من أعمال الصلاة إذا كان من غير العبا.

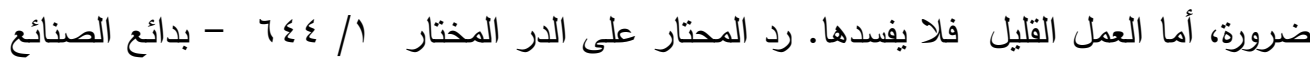

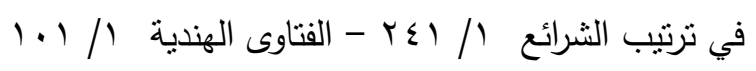

(1) حيث ذكروا: أن إثارة المصلي لطلب حاجة أو ردا على من طلب حاجة جائزة إذا كانت إثنارة

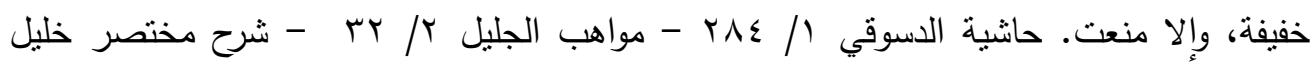

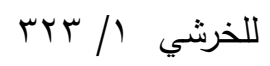
(r) فقد قالوا بأن المصلي إذا عمل في الصلاة عملا ليس من جنسها وكان قليلا فلا نبطل صلاته

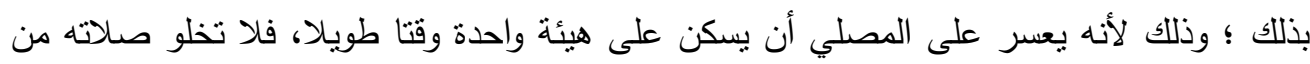

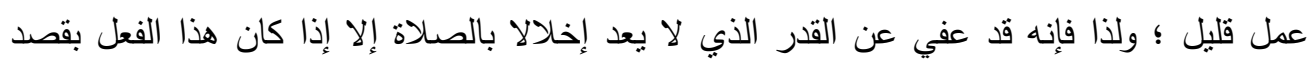

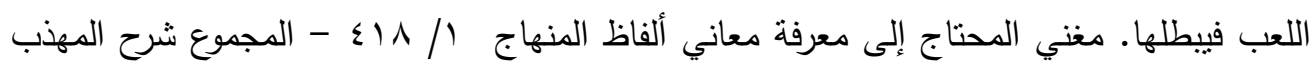

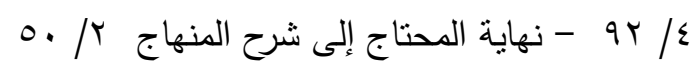

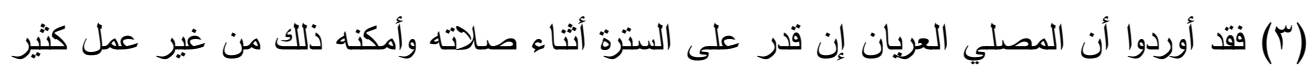

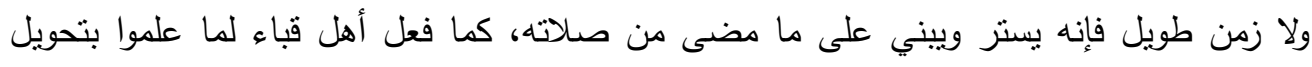

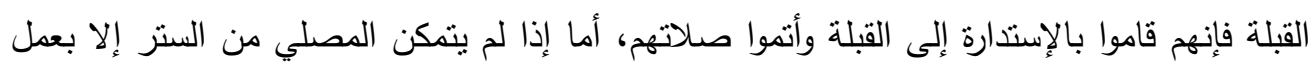

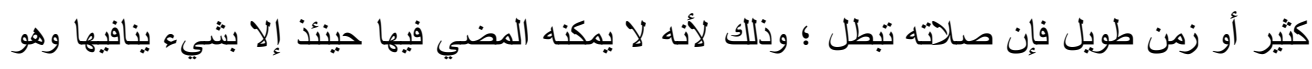

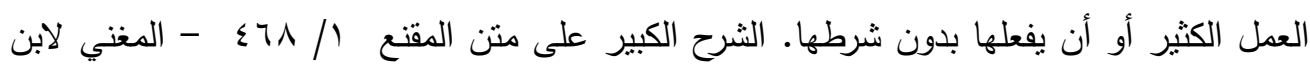

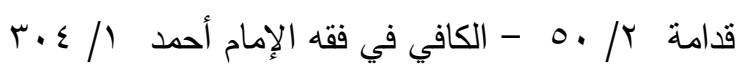

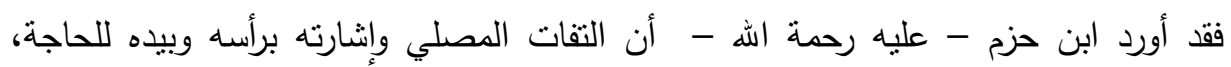
واستماعه إلى ما يأتيه وهو في الصلاة لحاجة في دينه أو دنياه - فكل ذلك مباح في الصنات الصلاة.

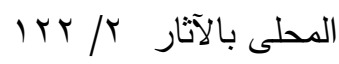
(0) حيث حكى أبو جعفر الطحاوي أنه ذهب قوم إلى أن أن الإثشارة التي تفهم إذا صدرت من الرجل

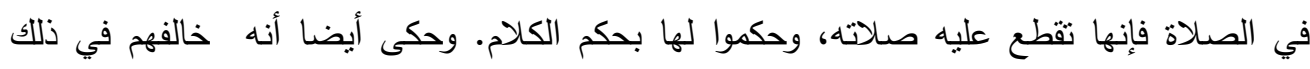

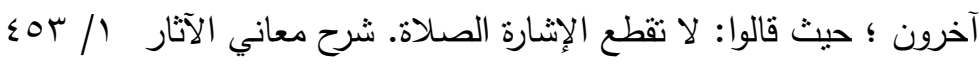

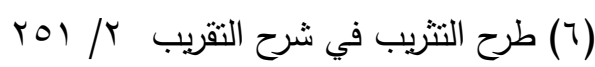


استدل أصحاب القول الأول على جواز الإشارة في الصلاة لأمر ينزل فيها أو لحاجة تطرأ على المصلي بما يلي:

\section{من السنة :}

ا - عن جابر بن عبد الله قال: اشتكى رسول الله صلى الله عليه وسلم فصلينا وراءه وهو قاعد، وأبو بكر بسمع الناس تكبيره، فالتقت إلينا فرآنا قياما، فأثار إلينا فقعدنا

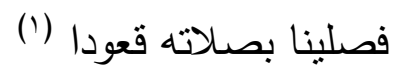

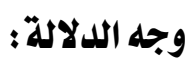

دل هذا الحديث الشريف على جواز الإشارة والعمل القليل في الصلاة للحاجة، ويستتبط منه جواز تكليم المصلي لغرض يعرض وجواز الرد بالإشارة (r) r- ما ورد عن أم سلمه - رضي الله عنها- عندما كان النبي- صلى الله عليه وسلم - يصلي في بيتها الركعتين بعد العصر ، قالت: " سمعت النبي- صلى الله عليه

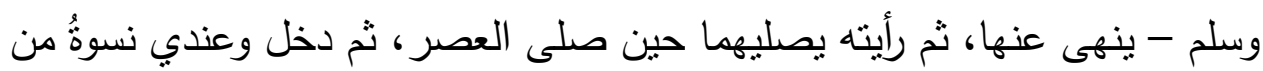
بني حرام من الأنصار فأرسلت إليه الجارية، فقلت: قومي بجنبه قولي له: تقول للك أم سلمه: يا رسول الله، سمعتلك تتهى عن هاتين وأراك تصليهما، فإن أشار بيده،

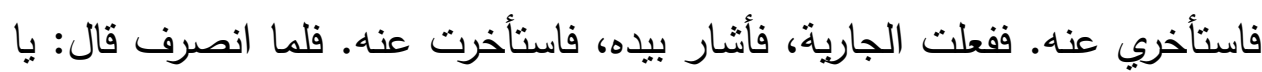
بنت أبي أمية، سألت عن الركعتين بعد العصر وإنه أتاني ناسُ من عبد القيس فتشغلوني عن الركعتين اللتين بعد الظهر، فهما هاتان" (ّ).

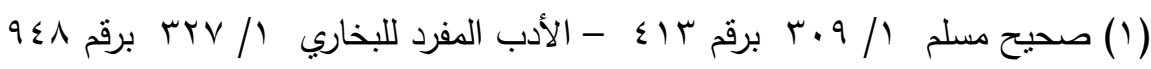

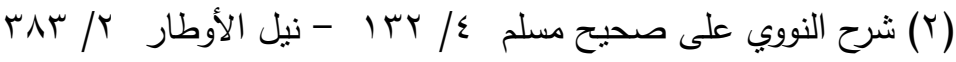

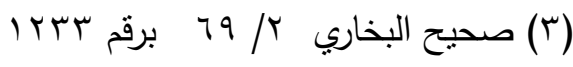


دل هذا الحديث على جواز إثارة المصلي باليد في الصلاة لمن كلمه في حاجة (').

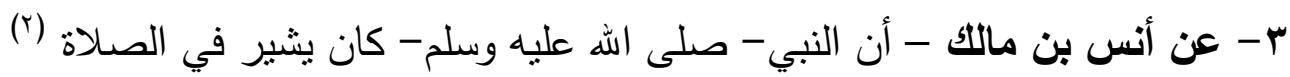
وجه الدلالة: إن الإشارة المذكورة في هذا الحديث - كما قال شراح الحديث- - تحمل

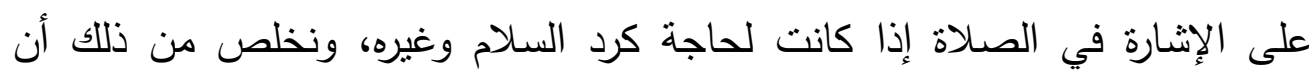

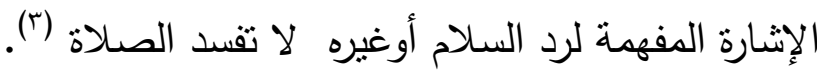
ع - عن جابر بن عبد الله قال: ذهب جبار بن صخر يقضي حاجته، فقام رسول الله لهارد صلى الله عليه وسلم ليصلي ثم جئت حتى قمت عن بسار رسول الله صلى الله عليه

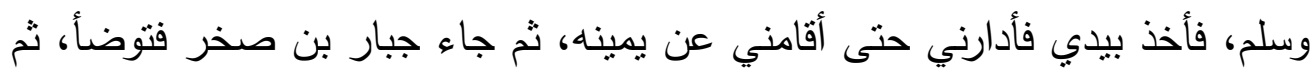
جاء فقام عن يسار رسول الله صلى الله عليه وسلم فأخذ رسول الله صلى الله عليه

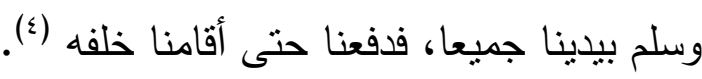
وجه الدلالة: دل هذا الحديث بوضوح على جواز العمل اليسير فى الصلاة وأنه أمر غير مكروه ما

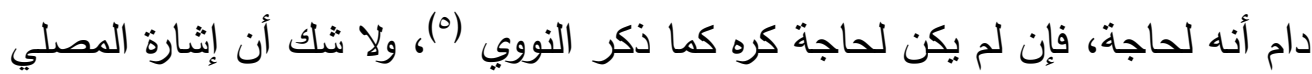
لغيره من جنس العمل اليسير لحاجة فتأخذ حكمه. ه- عن معيقيب، أن رسول الله صلى الله عليه وسلم، قال في الرجل يسوي التراب

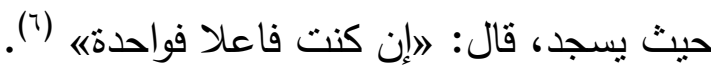

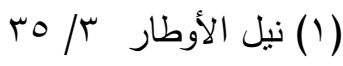

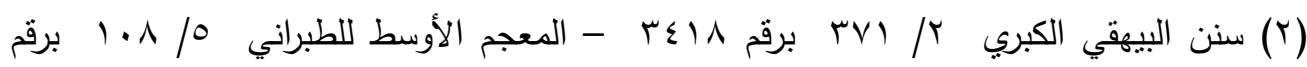

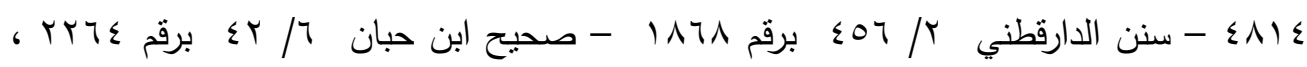

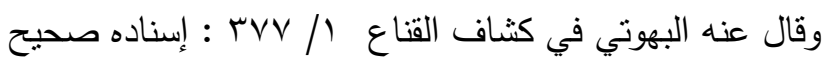

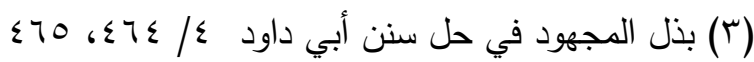

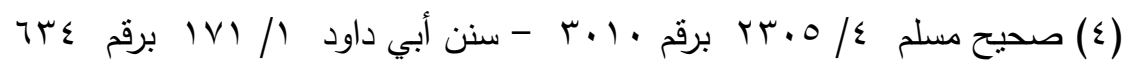

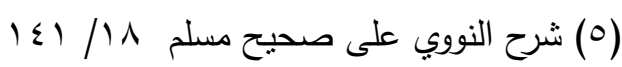

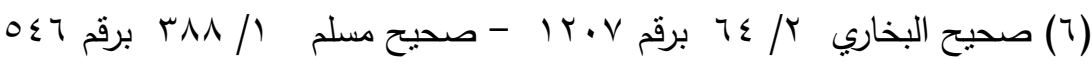




\section{وجه الدلالة:}

في هذا الحديث دلالة على أنه يجوز للمصلي ان يسوي التراب بفعلة واحدة ، وأبيح له مرة واحدة لكونه أمرا خفيفا وليدفع ما يتأذى به منها، أما ما زاد عليها فيمنع منه لئلا لئل

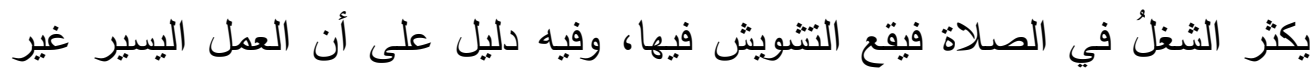
مبطل الصلاة (1)، ولا شك أن الإشارة لا تخرج عن كونها عملا يسيرا.

من المققول:

أن سكون المصلي على هيئة واحدة زمنا طويلا يعد أمرا عسيرا يتعذر الاحتراز منه، لذا عفي للمصلي عن القدر القليل الذي لا يخل بالصلاة إذا كان لحاجة (؟)، والإشارة تعد من هذا القبيل فهي عمل قليل لحاجة تطرأ على المصلي.

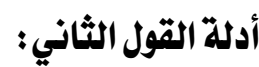

استدل أصحاب القول الثاني على أن الإشارة في الصلاة لأمر ينزل فيها أو لحاجة تعرض للمصلى تقسد الصلاة بما يلي: عن أبي غطفان، عن أبي هريرة، قال: قال رسول الله صلى الله عليه وسلم: 》التسبيح للرجال- يعني في الصلاة- والتصفيق للنساء، من أنشار في صلاته إثارة تفهم عنه، فليعد لهاه يعني الصلاة (ז).

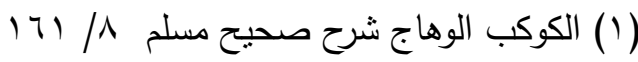

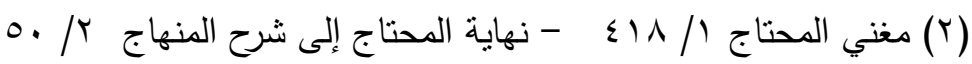

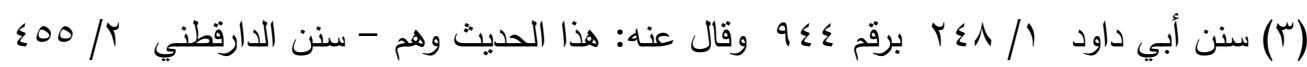

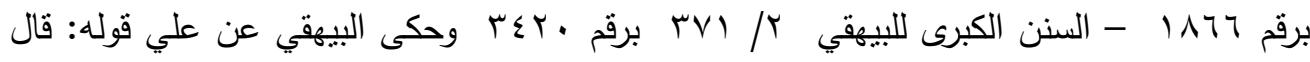

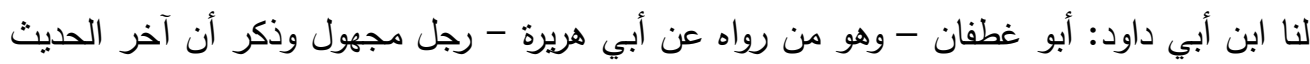

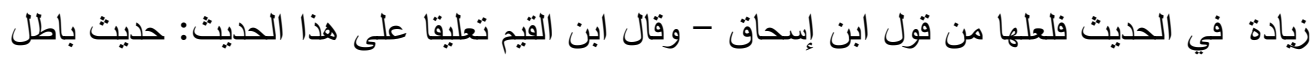

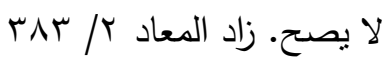




\section{وجه الدلالة:}

حيث دل هذا الحديث صراحة على أن الثخص الذي في الصلاة إذا صدرت منه إثنارة مفهمة فإنها تقطع عليه صلاته وتبطلها؛ وذلك أنها في حكم الكلام (').

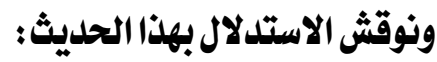

بأن المحدثين لم يسلموا بصحته؛ فقد ذكر أبو داود راوي الحديث: أن هذا الحديث وهم (r)، وأوضح ابن الجوزي أن هذا الحديث لا يصح عنه- صلى الله عليه وسلم لأن ابن اسحاق مجروح ، وأبا غطفان مجهول (זّ)، وقال زين الدين العراقي: هذا حديث ضعيف (๕).

وقال الدارقطني في سننه بعد أن ذكر هذا الحديث: " قال لنا أبن أبي داود: إن أبا غطفان هذا رجل مجهول، كما أن آخر الحديث زيادة في الحديث، فلعله من قول ابن اسحاق، والصحيح عن النبي- صلى الله عليه وسلم - أنه كان يشير في الصلاة، وهو ما رواه أنس وجابر وغيرهما " (0).

ثم لو سلم بصحة هذا الحديث، فينبغي أن تحمل الإثارة المذكورة فيه على الإثارة لغير رد السلام والحاجة، أو يحمل الأمر بالإعادة على الاستحباب؛ جمعاً بين الأدلة (†). القول المختار:

بعد عرض القولين في المسألة تميل النفس إلى اختيار القول الأول القائل بأن

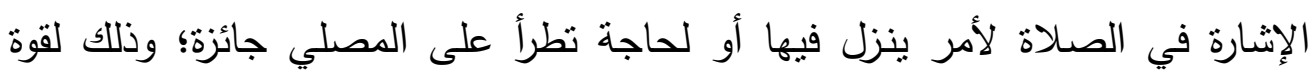

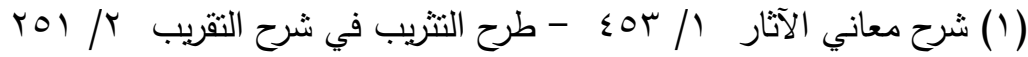

$$
\begin{aligned}
& \text { r }
\end{aligned}
$$

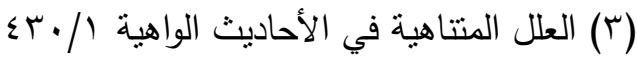

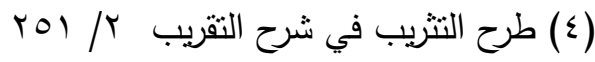

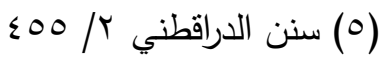

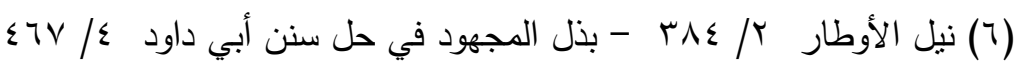


دليله وسلامته من النقاش، وضعف القول الثاني، ووهن مستتده، ويكفي هذا القول وهنا أن قائله غير معروف؛ فالبعض عزاه لقوم لم يسمهم، والبعض عزاه للحنفية، في حين

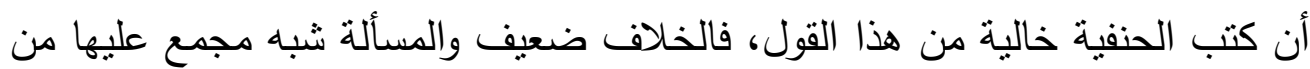
السادة الفقهاء الأجلاء من حيث المبدأ وهو الإشارة لحاجة. أما ما اختلفوا فيه: فهو القدر المسموح به في استعمال الإشارة؛ لأن الإشارة - كما لا يخفى على أحد - تعد عملا من غير جنس الصلاة، فلو زادت كانت عملا كثيرا مبطلا للصلاة عند جميع الفقهاء. ولكن حد هذه الكثرة مختلف فيه:

فالأصح عند الحنفية ومذهب المالكية: أن العمل الكثير المبطل للصلاة هو ما يخيل للناظر أن فاعله ليس في الصلاة، فإن شك في كونه في الصلاة أو لا فهو عمل قليل، واستثنى الحنفية من ذلك العمل الكثير الذي هو لإصلاح الصلاة فرغم كونه كثيرا إلا أنه لا ييطل الصلاة (') أما الثافعية والحنابلة فقالوا بأن المرجع في معرفة القلة من الكثرة هو العرف، فالقدر الذي يعده الناس قليلا فهو قليل، والذي يعدونه كثثرا فهو كثثر . لكن الثافعية فسروا هذا القدر القليل المتعارف عليه بكونه نحو الخطوتان المتوسطتان أو الضربتان، أما الثالاث من ذلك أو غيره فهو كثير إن نوالى سواء أكانت من جنس واحد كالخطوات، أم أجناس: كخطوة وضربة وخلع نعل. أما الحنابلة فقالوا لا توقيف في تحديد اليسير ولا الكثير ؛ لذا لا يتقدر بثلاث وهات ولا بغيرها من العدد، بل اليسير هو ما عده العرف يسيرا؛ فالقبض مثلا إن طال عرفا ما

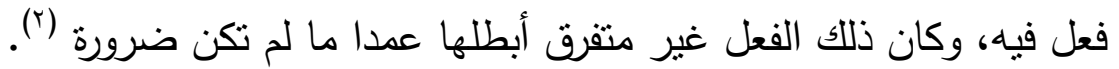
وتميل النفس إلى اختبار قول الحنابلة لقوة توجيههم للدعاهم، وعليه: إن كثرت الإثارات المستعملة في الصلاة بما يعده العرف كثيرا وكان غير متفرق أبطل الصلاة.

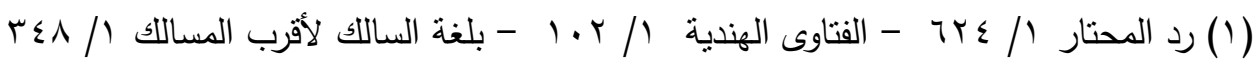

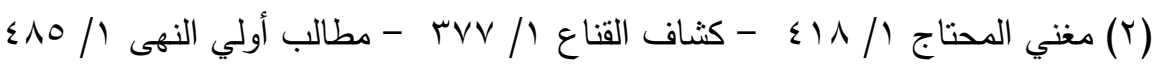


إشارة الجسل من مظاهر التيسير ورفع الحرج في الفقه الإسلامي

د/حليه رجب كامل السيل

ومن هنا يتضح لنا مدى تيسير الثريعة الإسلامية على المكلقين ورفع الحرج عنهم؛ حيث أباحت لهم استعمال إثارة الجسد في الصلاة، وهي من المواطن التي لا يجوز فيها استعمال اللفة الناطقة، ولكن هذه الإباحة لحاجة ويقدر معين يحصل به المطلوب. 


\section{المطلب الثاذي \\ إعمال إشارة الجسل أثناء خطبة الجمعة}

في البداية ينبغي علينا أن نعرف هل الحاضرين لخطبة الجمعة يحرم عليهم الكلام أم لا، وذلك حتي نبني كلامنا بعد ذلك من استعمال إثنارة الجسد أثناء خطبة الجمعة دن قبل الحاضرين لها.

والمتتبع لكتب الفقهاء يرى أن في هذه المسألة قولين: القول الأول: أن الكلام محرم على الحاضرين أثناء خطبة الجمعة، وبجب الإنصات عليهم من حين يأخذ الإمام في الخطبة. وهو قول جمهور الفقهاء: الحنفية (') والمالكية (r) والحنابلة (r) والثافعية في القديم (ع) والظاهربة (0)

(1) فقد جاء في كتبهم أنه بحرم الكلام في الخطبة حتى وإن كان تشبيحا أو أمرا بمعروف، وكذلك

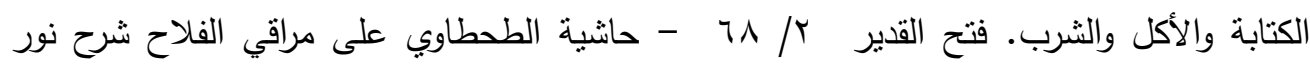
or. / الإيضاح (Y) فقد بينوا أنه يجب على كل من شهد الجمعة من المكلفين الإنصات للإمام في خطبته الأولى والثانية وكذا حال الجلوس بينهما حتى يفرغ من الخطبة الثانية. الفواكه الدواني على رسالة ابن أبي

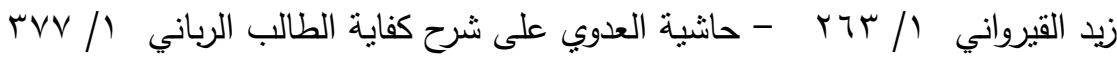
(r) فقد جاء في كتبهم أنه من حين يأخذ الإمام في الخطبة يجب الإنصات ولا يجوز لأحد من الحاضرين أن يتكلم، ونقلوا النهي عن ذلك عن ابن عمر وعثمان، ورووا عن ابن مسعود أثرا يأمر فيه

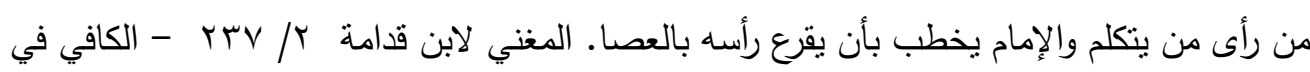

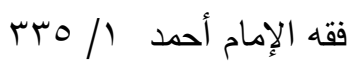

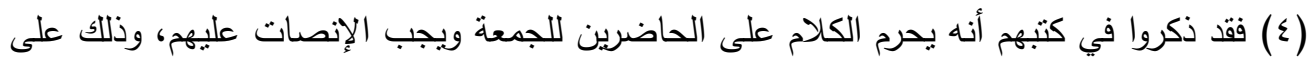
القديم، أما على الجديد فلا يحرم على الحاضرين الكلام فيها بل هو أمر مكروه. مغني المحتاج إلى

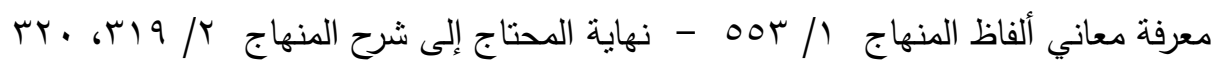
(0) فقد قرر ابن حزم أن كل من حضر الجمعة سواء سمع الخطبة أو لم يسمع فإنه يفرض عليه مدة

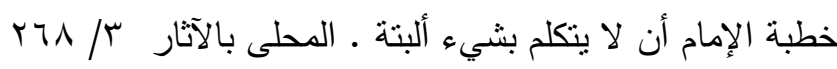


القول الثاني: أن الكلام لا يحرم على الحاضرين أثناء خطبة الجمعة ولكنه أمر مكروه، ويسن لهم الإنصات فيها.

وهو قول الثافعية في الجديد (') ورواية عن أحمد الإنهات

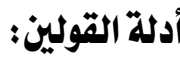

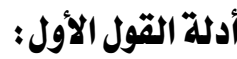
استدل أصحاب القول الأول على حرمة الكلام على الحاضرين أثتاء خطبة الجمعة ووجوب الإنصات عليهم بما يلي: من الكتاب:

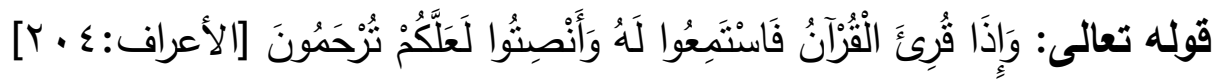

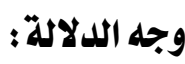
فقد قال مجاهد وسعيد بن جبير وعمرو بن دينار وعطاء ومسلم بن بسار وزيد بن أسلم وعبد الله بن المبارك وشهر بن حوشب: أن هذه الآية نزلت في الخطبة، وقال الإمام

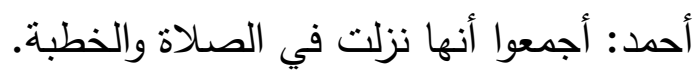
وقال بعض المفسرين: لا يختص هذا الإنصات المأمور به بخطبة الجمعة بل يشمل أيضا خطبتي الفطر والأضحى وكل ما يجهر فيه الإمام (r)، وسميت الخطبة قرآنا

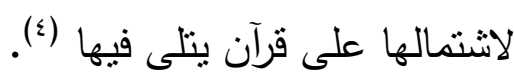
من السنة : n من عن أبي هريرة أن رسول اله صلى الله عليه وسلم، قال: " إذا قلت لصاحبك: أنصت، يوم الجمعة، والإمام يخطب، فقد لغوت " (0).

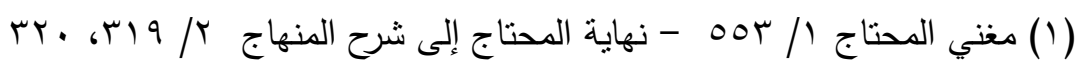

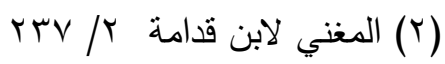

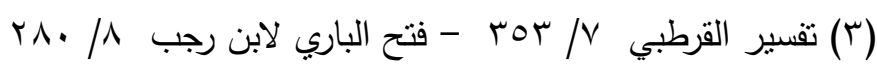

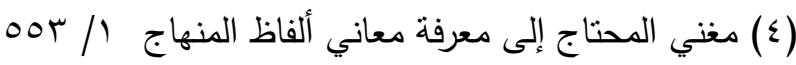

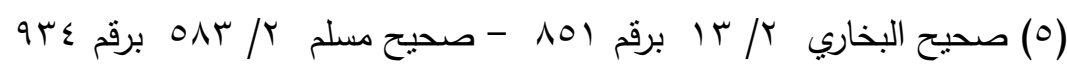




\section{وجه الدلالة:}

في هذا الحديث الثريف نهي عن جميع أنواع الكلام أثتاء الخطبة، فحيث نهي

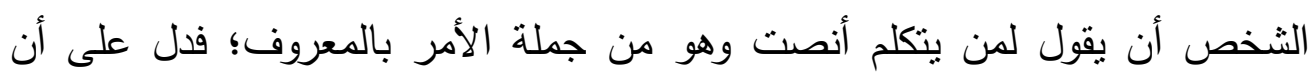
الكلام فيما سواه منهي عنه من باب الأولى، ومعنى قوله لغوت: أب قلت اللغو وهو

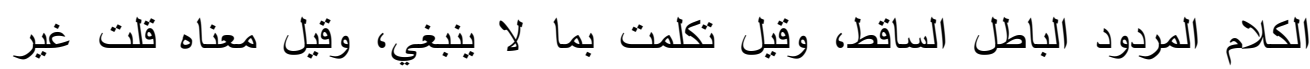

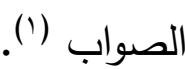

من المققول:

أن الخطبة إنما وجبت في الجمعة موعظة للناس وتذكيراً لهم، فاذا لم يجب

عليهم استماعها لم تبق فائدة في وجوبها في نفسها؛ ثم إن إيجاب المتكلم بما لا يجب استماعه يعد من قبيل اللغو الذي لا فائدة له (؟).

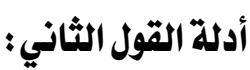

استنل أصحاب القول الثاني على أن الكلام لا يحرم على الحاضرين أثثاء خطبة

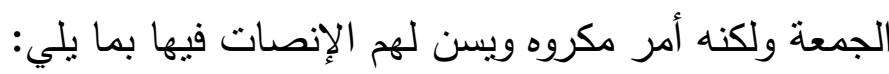

من السنة:

عن أنس بن مالك، قال: أصابت الناس سنة على عهد النبي صلى الله عليه وسلم، فبينا النبي صلى الله عليه وسلم يخطب في يوم جمعة قام أعرابي، فقال يا رسول الله: هلك المال وجاع العيال فادع الله لنا، فرفع يديه وما نرى في السماء قزعة، فوالذي

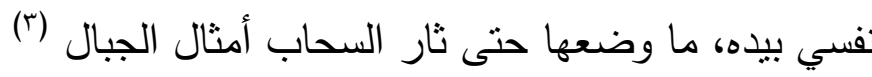

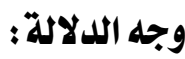

أنه لم ينكر عليه الكلام ولم يبين له وجوب السكوت ولا يختص هذا بالأربعين بل

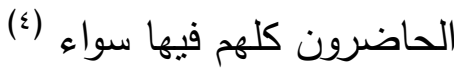

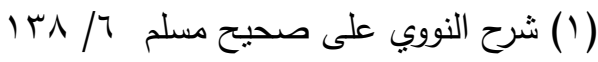

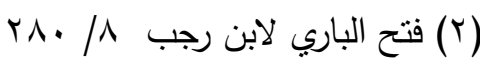

(ץ) صحيح البخاري

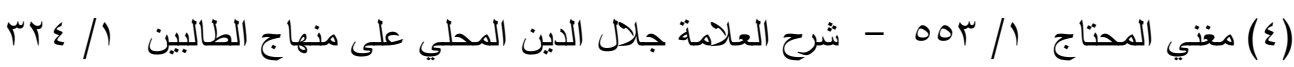




\section{ويمكن مناقشة الاستدلال بهذا الدليل :}

بأن أقصى ما يدل عليه هذا الحديث هو إباحة تكليم الحاضر لخطيب الجمعة لحاجة، وهذه المسألة وقرينتها: وهي تكليم الخطيب للحاضر من الأمور التي أجازها أصحاب القول الأول القائلين بوجوب الإنصات لخطبة الجمعة وحرمة الكلام فيها: فقد ذكر المالكية: أن الخطيب إن خاطب إنسانا في أمر من الأمور جاز لهذا الثخص إجابته، كما أنه إذا كلم أحد الخطيب في أمر جاز لله إجابته، كقول الإمام علي لمن سأله وهو على المنبر صار ثمنها تنعا ('). ونص الحنابلة: على أنه لا يحرم الكلام على الخطيب، ولا على الثخص الذي سأله

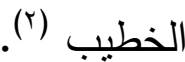
وقرر الظاهرية: أنه يجوز في الخطبة ابتداء الخطيب بالكلام ومجاوبته، وابتداء صاحب الحاجة له تعالى بالمكالمة وجواب الخطيب له (َّ). واستدلوا جميعا على ذلك: إبه 1- بحديث أنس السابق الذي طلب فيه الأعرابي من النبي صلى الله عليه وسلم الاعاء.

r- وبما روي عن عبد الله بن عمر أن عمر بينما هو يخطب الناس يوم الجمعة دخل

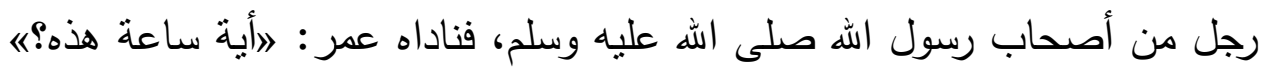
فقال: إني شغلت اليوم، فلم أنقلب إلى أهلي حتى سمعت النداء، فلم أزد على أن أن أنه توضأت، قال عمر: ارالوضوء أيضا، وقد علمت أن رسول الله صلى الله عليه

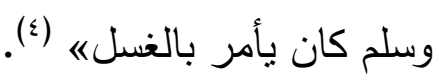

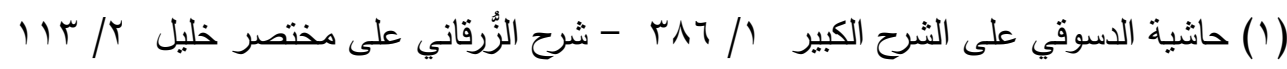

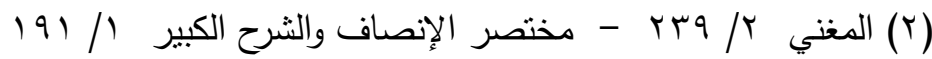

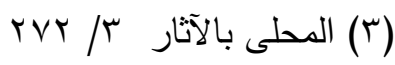

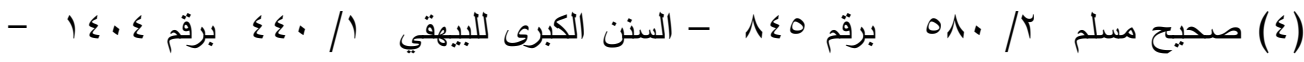

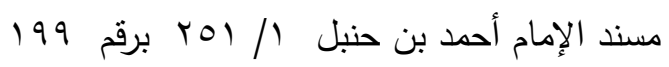


r- وبأن تحريم الكلام لله علة وهي الاشتغال به عن سماع الخطبة والإنصات الواجب، ومعلوم أن من كلمه الإمام لحاجة أو من سأل الإمام عن مسألة فإن هذه

العلة لا تتسحب إلبه (').

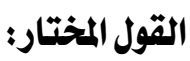

بعد عرض قولي المسألة ودليل كل قول يتضح لي رجحان القول الأول القائل

بحرمة الكلام أثناء خطبة الجمعة ووجوب الإنصات فيها؛ وذلك لقوة مستتده ووضوحه على الحكم المستدل له، أما أصحاب القول الثاني القائلين بأن الكلام في الخطبة لا لإهله يعدو أن يكون أمرا مكروها ويسن نركه والإنصات للخطبة فإنهم لما أرادو أن يدللوا

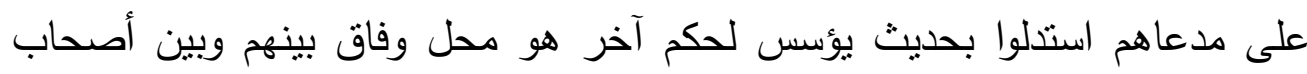
القول الأول، وهو جواز الكلام بين الخطيب وأحد المستمعين لحاجة، ويكفي قول بولين الثربيني الثافعي بأنه: لا يحرم الكلام قطعا على الخطيب، والخلاف إنما يكون في الكلام الذي لا يتعلق به غرض مهم ناجز (؟).

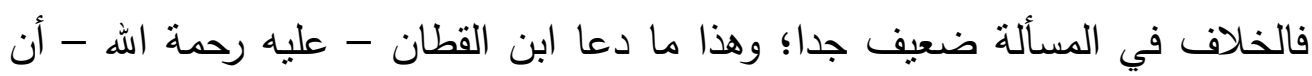
يقول: وفيما علمت لا خلاف في وجوب الإنصات للخطبة (ץ). ويعد أن تبين لنا حرمة الكلام أثناء الجمعة لا بد أن نتكلم عن مدى جواز استعمال إثارة الجسد خلالها، وهو ما سنتحدث عنه في المسألتنين الآتيتين:

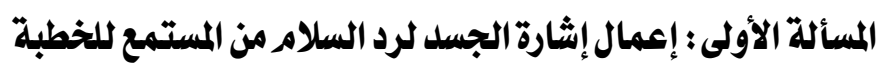
المتتبع لكتب الفقه الإسلامي يرى أن الفقهاء اختلفوا في حكم رد المستمع لخطبة الجمعة للسام بواسطة الإثارة بشيء من الجسد، وكان خلافهم على قولين: القول الأول: جواز رد المستمع لخطبة الجمعة للسلام بواسطة الإشارة. وهو قول عند المالكية (') ومفهوم مذهب الثافعية (r) والحنابلة (r) والظاهرية(؛)

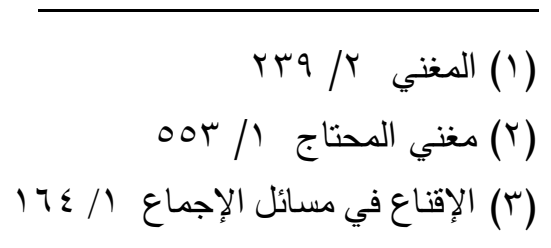


القول الثاني: تحريم رد المستمع لخطبة الجمعة للسلام بواسطة الإثارة.

وهو مذهب الحنفية (0) والمالكية (؟)

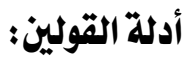

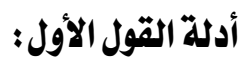

استذل أصحاب القول على جواز رد المستمع لخطبة الجمعة للسلام بواسطة الإثارة بما يلي:

أن الكلام محرم عليه فلا يجوز له أن يرد السلام باللفظ، ولكنه يجيب بالإشارة كما في

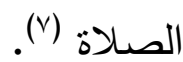

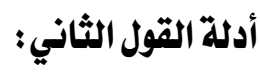

استذل أصحاب القول الثاني على حرمة رد السلام بالإثارة أثناء الخطبة بما يلي:

(1) فقد نقل ابن هارون عن مالك القول بجواز الرد بالإثارة. حاثشية الدسوقي على الثرح الكبير / /

ए人ᄉ

(r) لأنه لا يجب الإنصات لخطبة الجمعة على الجديد ومن ثم يجوز رد السلام نطقا ؛ فالإثارة

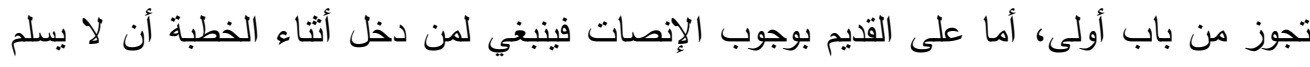

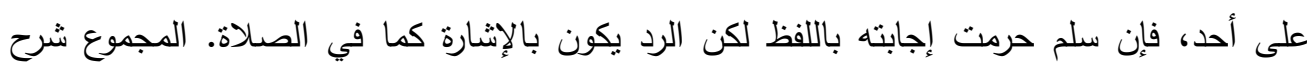

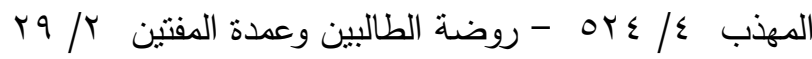

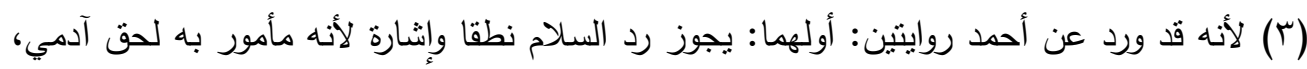

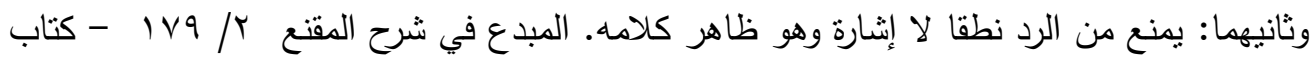

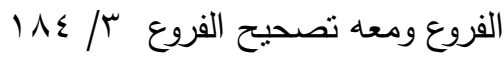
(ع) حيث أورد ابن حزم أن عدم الكلام على من حضر الجمعة أمر مفروض حتى وإن لم يسمع

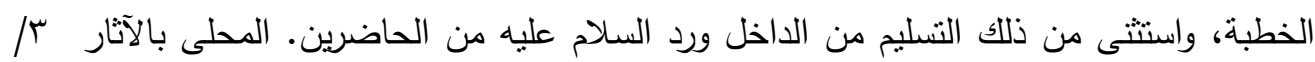

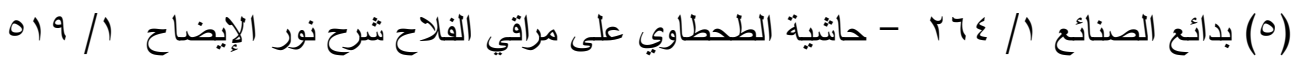

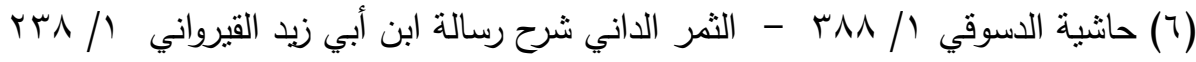

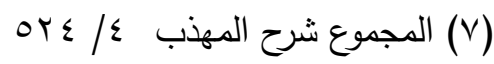


ا - أن رد السلام بالإشارة ينافي الإنصات الواجب حال الخطبة ولو على غير السامع،

وكل ما من شأنه أن ينافي الإنصات يحرم ولو كان شرب ماء أو حتى إثشارة (').

r- أن رد السلام أمره واسع ويمكن تحصيله في كل حالة، لكن سماع الخطبة لا

يتصور تحصيله إلا في تلك الحالة فكان إقامته أحق (r).

r- أن الثخص الذي يلقي السلام على مستمع الخطبة قد فعلا شيئا غير مأذون فيه شرعا؛ لأنه بذلك شغل خاطر السامع عن الفرض؛ لذلك لا برد عليه مطلقا لا

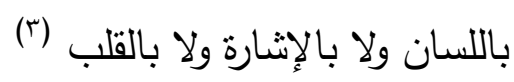

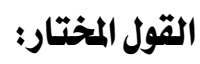

بعد عرض القولين في المسألة ومستتد كل منهما تميل النفس إلى اختبار القول الأول القائل بجواز رد المستمع لخطبة الجمعة للسلام بواسطة إثشارة جسده بالإثشارة

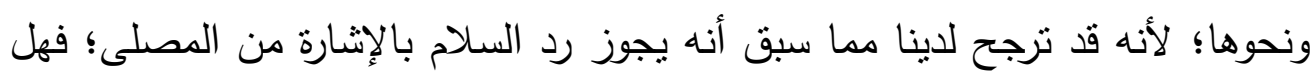

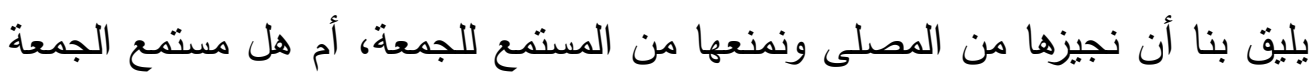
الذي يلتقت خلالها يمنة ويسرة لحاجة ومن غير حاجة ويكثر من الحركة يكون أثند التزاما من المصلي المنهي عن كل ذللك.

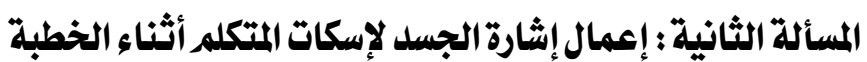

إذا رأى المستمع لخطبة الجمعة أحدا يتكلم أثناء الخطبة فهل يجوز له أن ينهاه بإنشارة

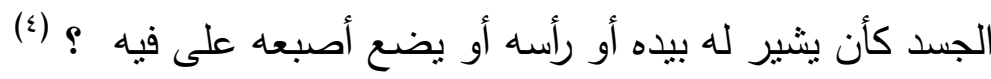
للإجابة على ذلك نقول: بأن الفقهاء اختلفوا في هذه المسألة، وكان خلافهم على قولين: القول الأول: يجوز للمستمع لخطبة الجمعة أن ينهي المتكلم خلالها بالإشارة.

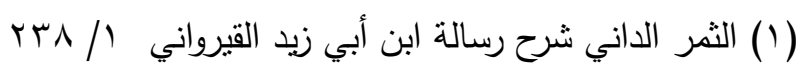

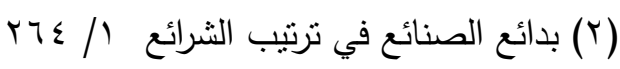

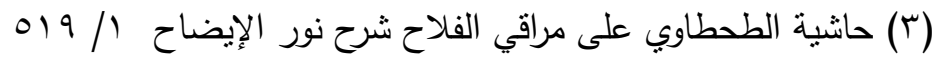

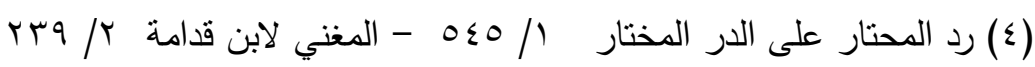


قال بذلك الحنفية (') والثافعية (r) والحنابلة (r) والظاهربة (£) القول الثاني: يحرم على المستمع لخطبة الجمعة أن ينهي المتكلم خلالها بالإشارة. وهو منصوص مذهب المالكية (0) أدلة القوليز:

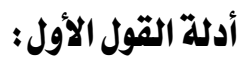
استدل أصحاب القول الأول على أنه يجوز للمستمع لخطبة الجمعة أن ينهي المتكلم خلالها بالإشارة بما بلي: من السنة:

ا- - عن أبي بن كعب: أن رسول الله - صلى الله عليه وسلم- قرأ يوم الجمعة لتباركي وهو قائم، فذكرنا بأيام الله، وأبو الدرداء أو أبو ذر يغمزني، فقال: متى أنزلت هذه

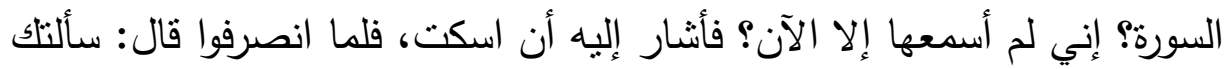
متى أنزلت هذه السورة فلم تخبرني، فقال أبي: ليس للك من صالتك اليوم إلا ما

(1) حيث جاء عندهم: أنه لا بأس من إثارته بالرأس أو البد عند رؤية منكر • رد المحتار على الدر المختار // / 0ـ0 - حاثية الطحطاوي على مراقي الفلاح شرح نور الإيضاح 19 (r) حيث ورد في كتبهم أنه إذا علم شخصا شيئا هو من الخير أو نهاه عن منكر فليس هذا بحرام قطعا بل قد يجب عليه ولكن يقتصر على الإثارة إن أغنت. مغني المحتاج إلى معرفة معاني ألفاظ

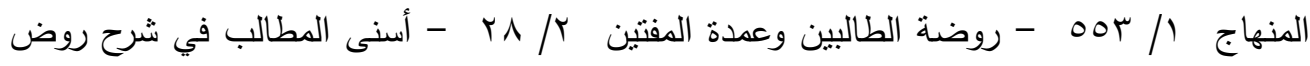

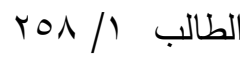
(r) حيث ورد في كتبهم أنه إذا سمع الإنسان منكلما لا ينهه بالكلام ولكن يشير إليه بأن يضع

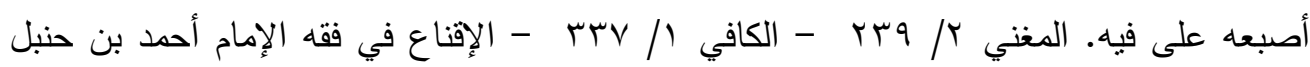
$191 / 1$

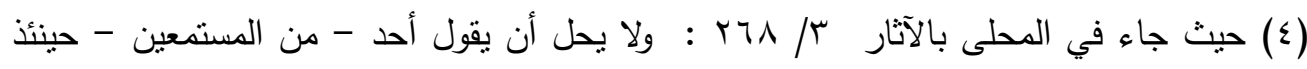
لمن يتكلم: انصت، ولكنه يشير إليه أو يغمزه أو يحصبه

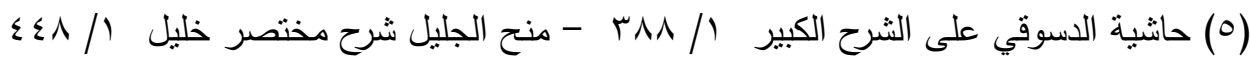


لغوت، فذهب إلى رسول الله - صلى الله عليه وسلم - فذكر ذلك له، وأخبره بالذي

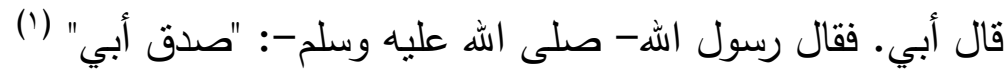

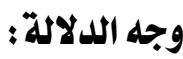

حيث أثنار أبي بن كعب إلى المتكلم أثناء خطبة الجمعة بالسكوت، وأخبره بأن ليس لله اليوم من أجر صلاته شيء لأجل لغوه وإعراضه عن استماع الخطبة، فتقدير كلامه: ليس للك من صلاتكا إلا لغوك؛ وأقره النبي صلى الله عليه وسلم على ذللك، لهن

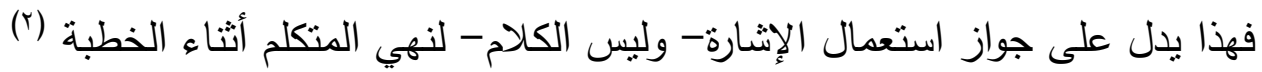

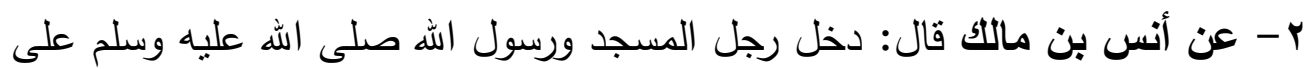

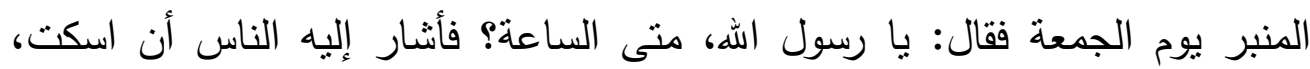
فسأله ثلاث مرات، كل ذلك يشيرون إليه أن اسكت، فقال له رسول الله صلى اله عليه

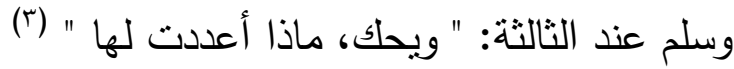

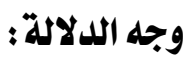

حيث أثنار الناس بالسكوت إلى الرجل الذي قطع على النبي صلى الله عليه وسلم

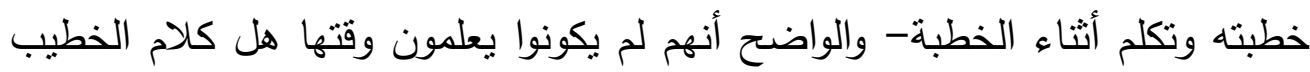

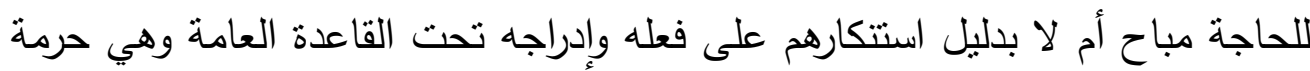
الكلام أثناء الخطبة- فهذا يدل بطريقة ليس هنالك أوضح منها على جواز الإثارة للمتكلم أثناء الخطبة أن يسكت؛ لحدوث ذلك بحضرته صلى الله عليه وسلم (ء).

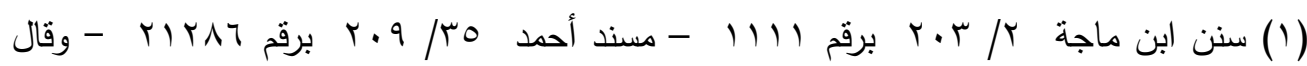

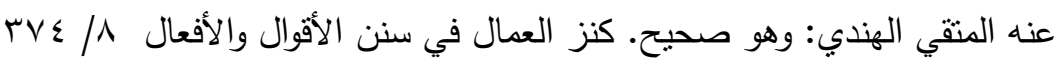

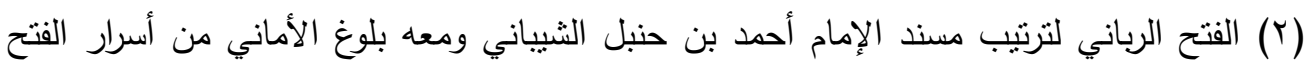

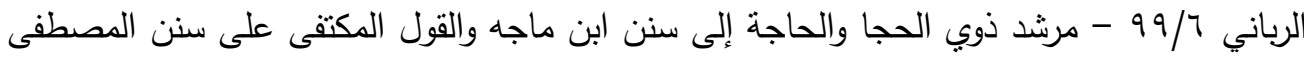
$111 / \mathrm{V}$

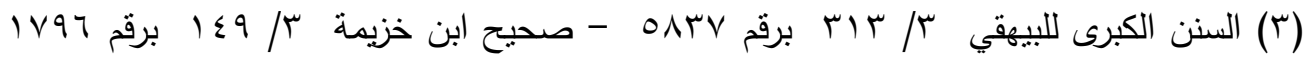

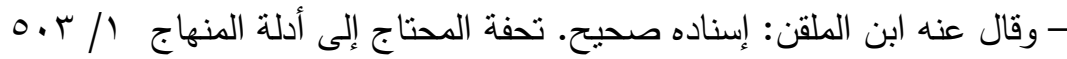
r 
أن الإثارة تجوز أثناء الصلاة للحاجة، والصلاة أمرها أخطر من الخطبة فالكلام يبطلاه، فتجوز الإشارة في الخطبة من باب أولى (').

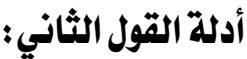
استدل أصحاب القول الثاني على أنه يحرم على المستمع لخطبة الجمعة أن ينهي

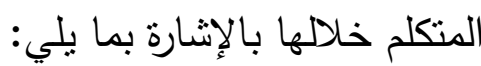
ا- أنه يجوز للخطيب أن ينهى الشخص الذي يلغو حال الخطبة وهو الذي يسكته،

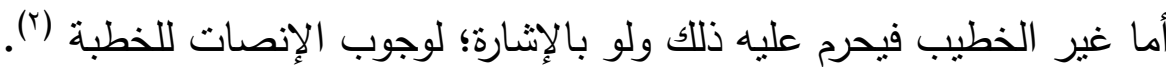
r- أنه لا يجوز لمن حضر الخطبة أن ينهى شخصا لغا بالكلام - كأن يقول له يحرم عليك أن تلغو حال الخطبة- أو بالحصب- كأن يرميه بالحصباء زجرا له عن لغوه-

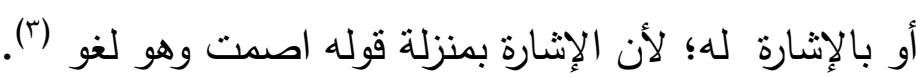
القول المختار: بعد عرض القولين في المسألة وذكر مستتد كل منهما تميل النفس إلى اختيار

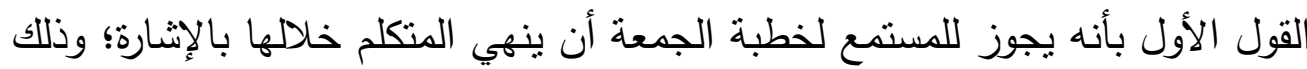

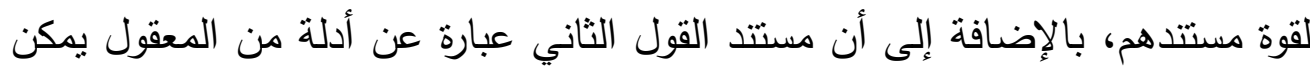
الطعن عليها؛ وذلك لأن قولهم بأن الخطيب يمكنه أن ينهى اللاغي فلا يجوز للمستمع- يمكن أن يرد عليه بأن الخطيب قد لا يرى المتكلم أو يؤدي ذلك إلى تشتيته

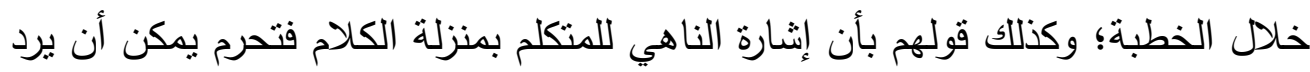

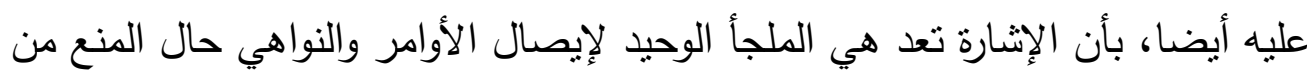

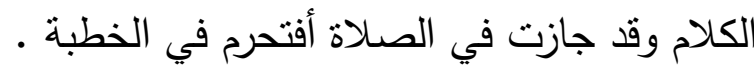

r

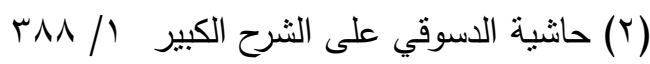

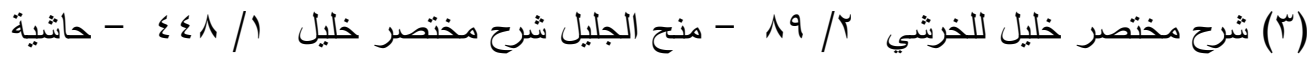

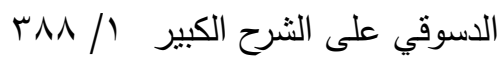


إشارة الجسل من مظاهر التيسير ورفع الحرج في الفقه الإسلامي د/حليه رجب كامل السيد

ويعد ذكر هاتين المسألتين تتجلى لنا عظمة الثريعة الإسلامية وتيسيرها على المكلقين ورفع الحرج عنهم؛ حيث أنها أجازت للحاضر لخطبة الجمعة استعمال إثارة الجسد متى وجدت الحاجة إلى ذلك؛ وذلك كونـه ممنوعا من استعمال اللغة الناطقة. 


\section{المبحث الرابع}

\section{موقف الفقهاء من الاعتداد بإشارة الجسل في مجال المعاملات}

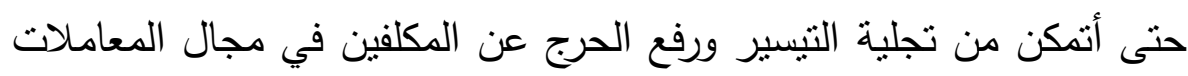
عن طريق إثارة الجسد سأقوم بتسليط الضوء على آراء الفقاء وأدلتهم في إجراء المعاملات عن طريق إثارة الجسد، وحتى أصل لتلك الغاية سأتكلم في البداية في المطلب الأول عن موقف الفقهاء من إثنارة الأخرس، ثم في المطلب الثاني سأتكلم عن مدى تأثير معرفة الأخرس بالكتابة على الاعتداد بإثارته، وفي المطلب الثالث سأتكلم

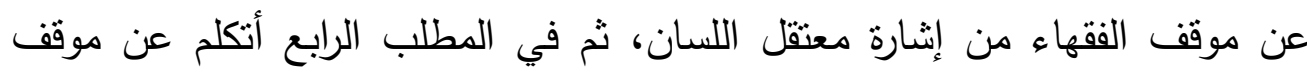
الققهاء من إثارة الناطق.

\section{المطلب الأول}

\section{موقف الفقهاء من إشارة الأخرس}

عرف أهل اللغة الأخرس بأنه: الذي منع من الكلام خلقة، والأنثى خرساء، والجمع منع منارة خرس بضم الخاء، ويقال كتيبة خرساء: أي لا بسمع لها صوت ولا جلبة، وناقة

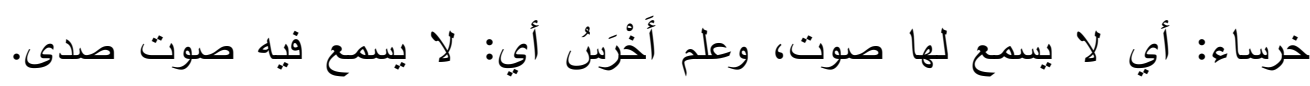

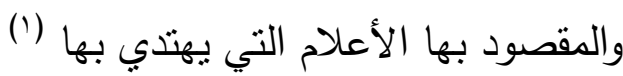

وورد في كتب الققهاء الأجلاء بأن الخرس: آفة باللسان تمنع الكلام أصلاً (؟)

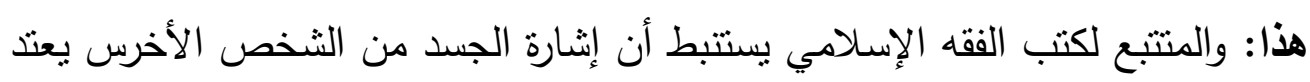

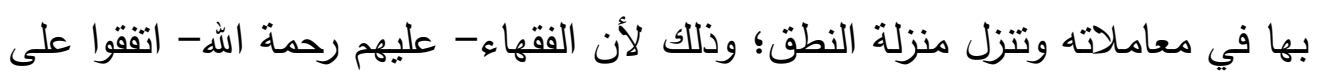

(1) كتاب العين: الخليل بن أحمد الفراهيدي ، المحقق: د مهدي المخزومي، د إبراهيم السامرائي،

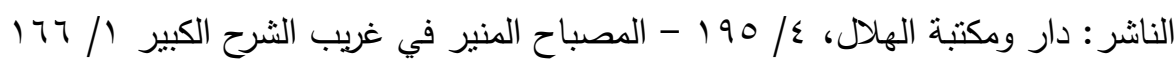

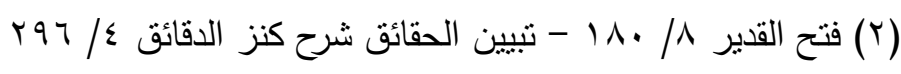


الاعتداد بالإشارة من الأخرس وعلى أنها تقوم مقام النطق (')، باستثناء بعض المسائل التي اختلفوا فيها (r). واستدل الفقهاء على ذلك بما يلي: 1- أن إثنارة الأخرس المعهودة منه كإثارته باليد أو الحاجب هي بمثابة البيان باللسان؛ لأن ذلك يدل على ما في فؤاده كما يدل عليه النطق من الناطق (').

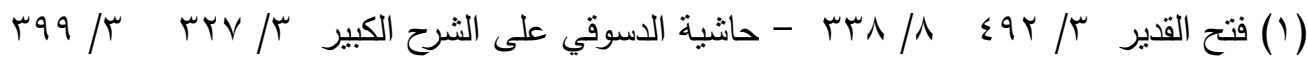

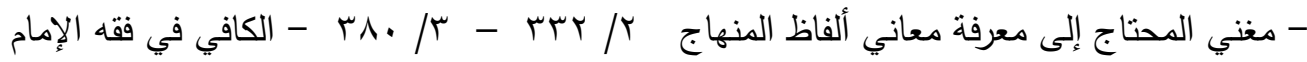

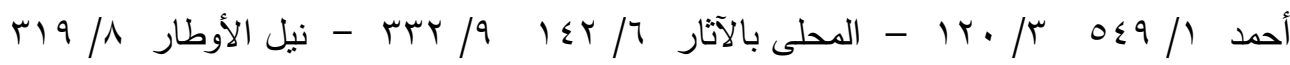
(r) فقد اختلف الفقهاء في انعقاد اليمين من الأخرس بالإثارة على قولين: أولاهما أنها تتعقد ويعتد بها بشرط أن تكون مفهومة وهو مذهب الحنفية والمالكية والحنابلة. درر الحكام في شرح مجلة

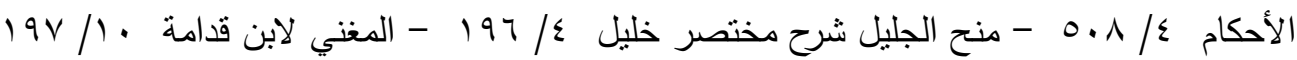
والثاني: أنها لا تتعقد ولا يعتد بها وهو مذهب الثافعية. المنتور في القواعد الفقهية / / 170

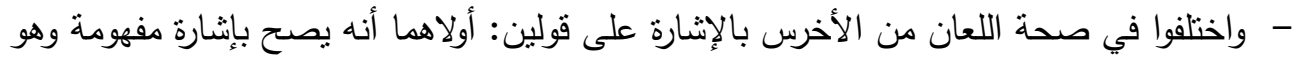

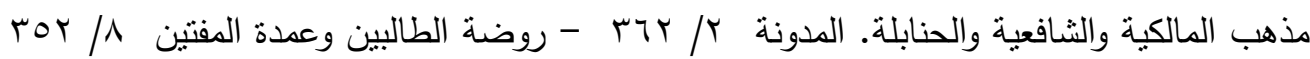

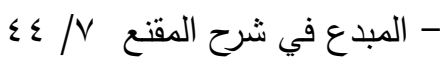

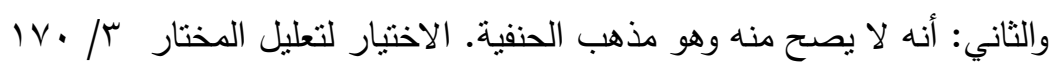

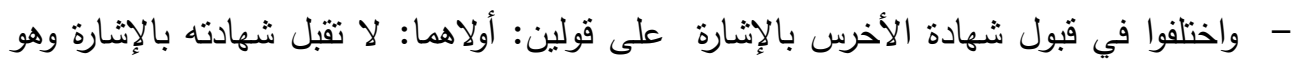

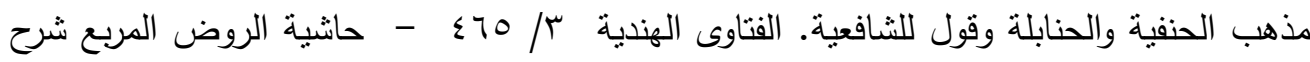

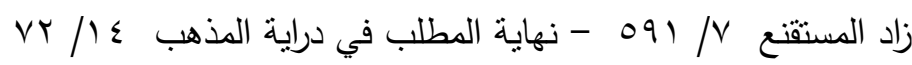
والثاني: تقبل شهادة الأخرس بالإثارة إذا كانت مفهومة وهو مذهب المالكية دالكية والقول الآخر للثشافعية.

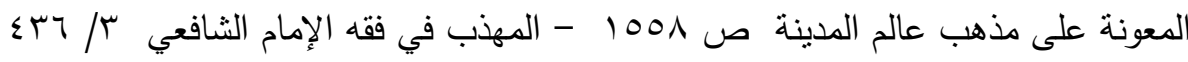

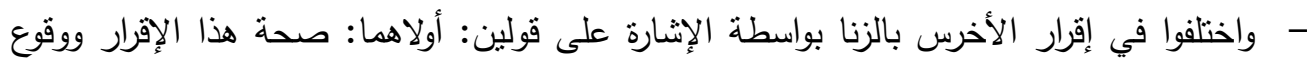

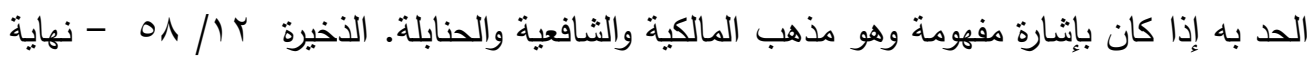

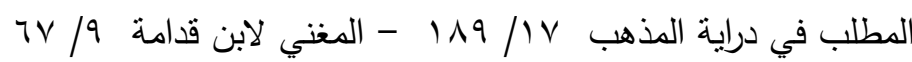
والثناني: عدم صحة هذا الإقرار ولا يقع به حد وهو مذهب الحنفية. رد المحتار على الدر المختار $9 / \varepsilon$ 
ץ- أن العاجز عن النطق بسبب الخرس إن لم تعتبر إثارته فلن تصح معاملته لأحد

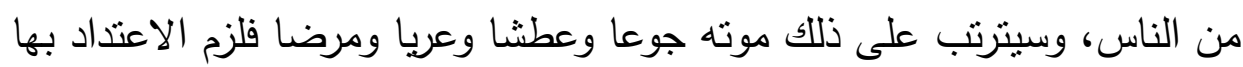

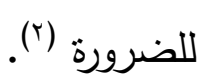

r- أن الإشارة فيها بيان، ولكن كل ما هنالك أن الثارع تعبد المكلفين الناطقين

بالعبارة، فإذا عجز الثخص عن العبارة أقامت الشريعة إثشارته مقام عبارته (ّ). واشترط الفقهاء لإنزال الإثارة من الأخرس منزلة النطق أن تكون الإشارة واضحة ومفهومة: ومعنى هذا الثرط أن لا يعتري الإثارة بشيء من الجسد أي غموض أو صعوبة في

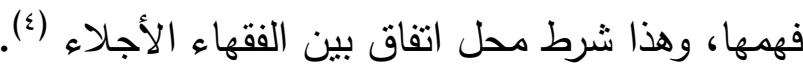

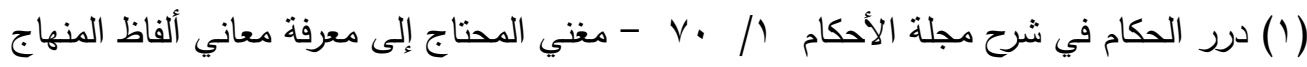

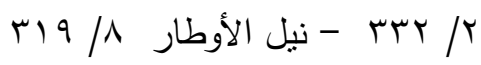

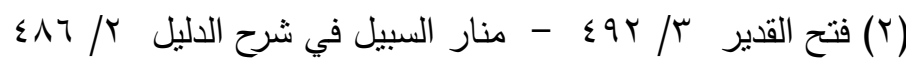

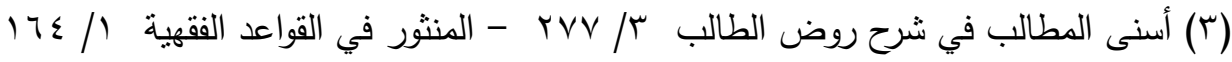

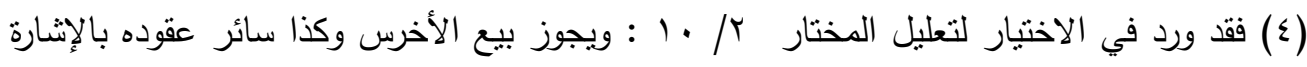
المفهومة وجاء في منح الجليل شرح مختصر خليل ـ/ 197 : وكذا الأخرس بإثارة مفهمة أو كتابة وجاء في مغني المحتاج 10 / 10 : ويلاعن أخرس بإثارة مفهمة أو كتابة

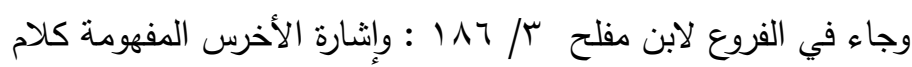




\section{المطلب الثاني \\ ملدى تأثير معرفة الأخرس بالكتابة على الاعتداد بإشارته}

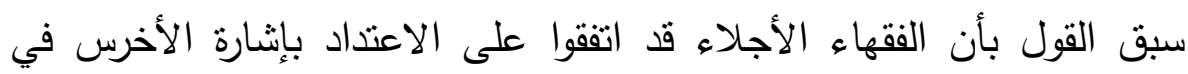

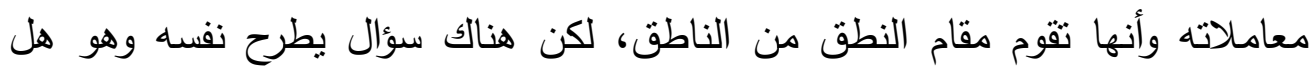
معرفة الأخرس بالكتابة تجعل الإثارة منه غير مقبوله لأن بإمكانه إنشاء التصرفات

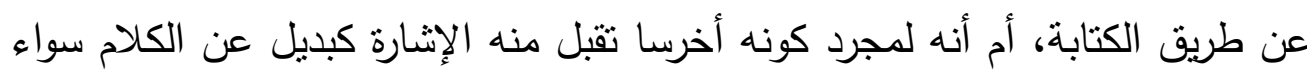

$$
\text { كان يعرف الكتابة أو لا يعرفها ؟ }
$$

وللإجابة على ذلك نقول بأن الفقهاء اختلفوا في تلك المسألة، وكان خلافهم على قولين:

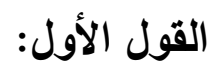

أن الأخرس العارف بالكتابة لا تقبل منه الإثارة؛ إذ العجز عن الكتابة يعد شرطا في

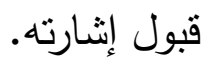

$$
\text { وهذا هو قول عند الحنفية (') وقول عند الثافعية (r) }
$$

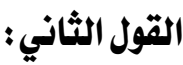

أن الأخرس العارف بالكتابة تقبل منه الإثارة؛ فالعجز عن الكتابة لا يعد شرطا في

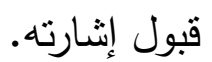

وهذا هو قول جمهور الحنفية (r) ومذهب المالكية (£) وقول جمهور الثافعية (•)

$$
\text { ومذهب الحنابلة (؟) وهول }
$$

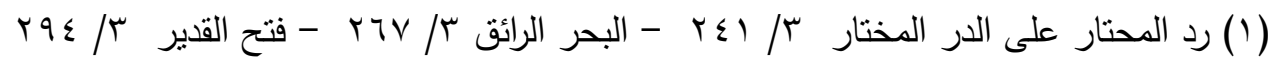

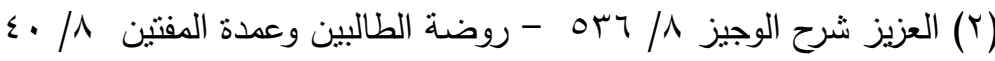

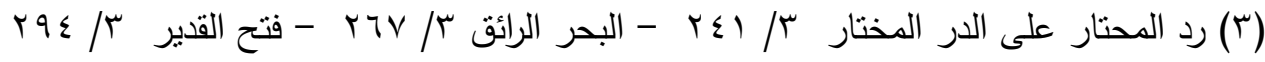

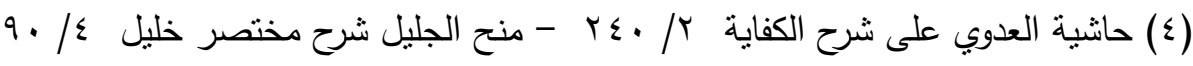

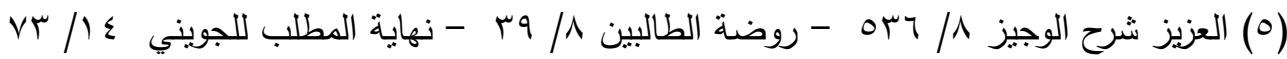

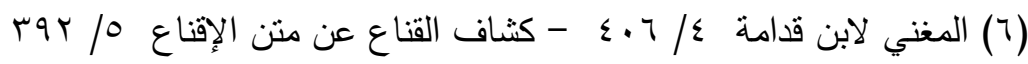


استدل أصحاب القول الأول على أن الأخرس العارف بالكتابة لا تقبل منه الإثشارة بدليل من المعقول. ويبانه: أن الإثشارة بشيء من الجسد بالنسبة للأخرس العاجز عن النطق أمر ضروري

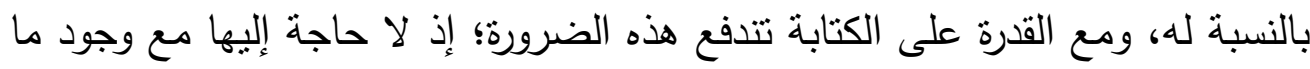

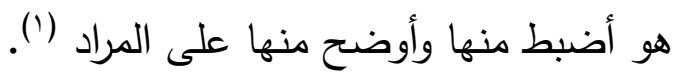
دليل القول الثاني: كان مستتدهم في عدم اثتراط العجز عن الكتابة للاعتداد بإنشارة العاجز عن النطق بدليل من المعقول أيضا. وييانه : أن الإشارة والكتابة كليهما أمر دعت إليه الضرورة فهما من هذه الجهة مستويان، بالإضافة إلى أن كل واحد منهما به ما ليس في الآخر ؛ فالإثارة فيها زيادة أثثر ليس موجودا في الكتابة؛ إذ إنها أقرب للنطق من آثار الأقلام، والكتابة فيها زيادة بيان ليس موجودا في الإشارة؛ إذ إن المقصود منها يكون مفهوما بلا أدنى شبهة (؟). القول المختار:

وتميل النفس لقول الجمهور من عدم اثتراط العجز عن الكتابة للاعتداد بإنشارة

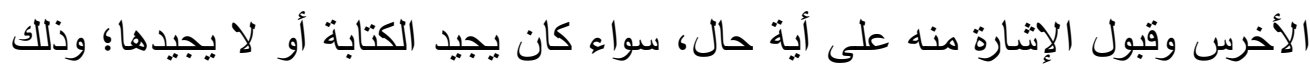
لقوة مستندهم، ولأنه الذي يتتاسب مع يسر الثريعة ورفعها الحرج عن المكلفين.

(1) مراجع الحنفية والثافعية المذكورة في الهامشين السابقين

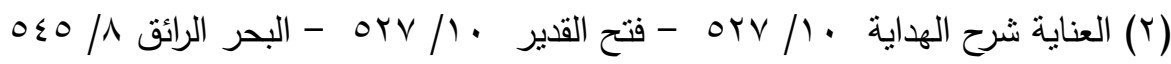




\section{المطلب الثالث}

\section{موقف الفقهاء من إشارة معتقل اللسان}

بداية نقول: بأنه جاء في كتب اللغة أن معتقل اللسان: هو من حبس لسانه ومنع منعارة الكلام، ومعنى لفظة اعتقل: حبس؛ يقال عقله عن حاجته: أي حبسه، وسمي العقل هون إل عقلا لأنه يعقل صاحبه عن التورط في المهالك أي يحبسه، والعاقل هو من يحبس التس نفسه ويردها عن هواها، وعقل الدواء بطنه: أمسكه بعد استطلاقه، لذا سمي الدواء

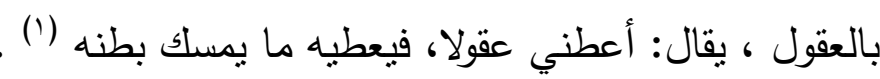

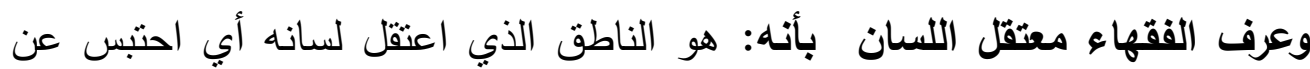

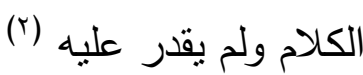

وأما عن اعتداد الفقهاء بإشارة من اعتقل لسانه وإنزالها منزلة النطق من الناطق :

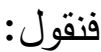

بأن السادة الفقهاء اختلفوا في هذه المسألة، وكان خلافهم على قولين:

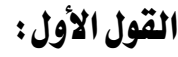

عدم الاعتداد بإنشارة معتقل اللسان حتى يحصل الإياس من نطقه.

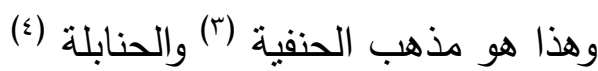

واليأس من النطق اختلفوا فيه، فقيل بامتداد اعتقاله شهر وقيل ستة أثنهر وقيل سنة وقيل حتى الموت، وقال البعض: يرجع فيه إلى قول عدلين من أطباء المسلمين (०)

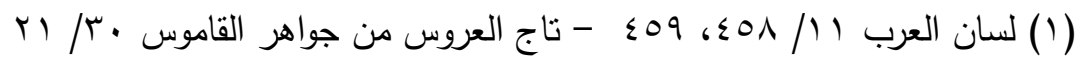

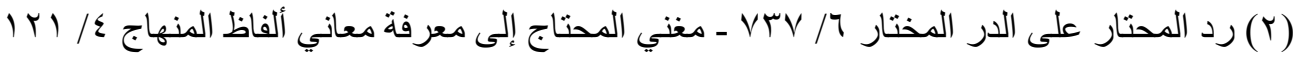

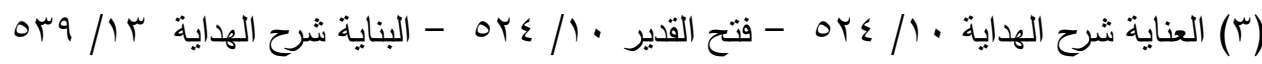

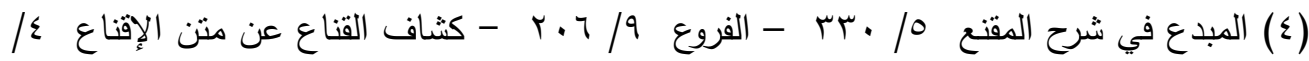

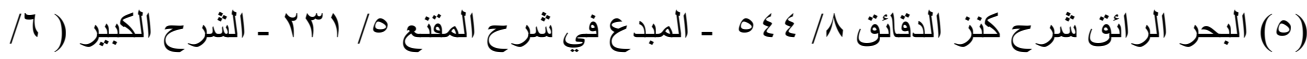

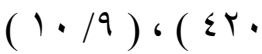


الاعتداد بإثارة معتقل اللسان مطلقا من دون توقف على الإياس من نطقه.

وهذا هو مذهب المالكية (') والثافعية (r) لإندارة معنية

الأدلة:

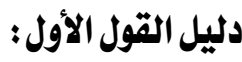

استدل أصحاب القول الأول على عدم الاعتداد بإثارة معتقل اللسان حتى يحصل الإياس من نطقه بأدلة من المعقول

وبيانها كالتالي:

1- أن الإشارة تم اعتبارها من الأخرس لأنها صارت معهودة معلومة، وذللك غير متحقق في المعتقل لسانه إلا إذا امتد وقت عجزه عن النطق وصارت لله إثنارات

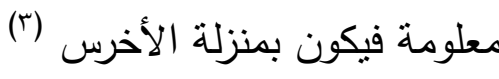
r- أنه تم اعتبار إثنارة الأخرس والاعتداد بها للضرورة اللازمة؛ إذ إن عجزه عن

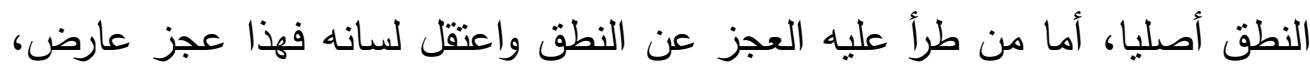

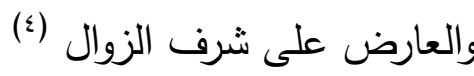
r - أن الثخص الناطق إن اعتقل لسانه ولم يتم الإياس من نطقه فإنه يكون

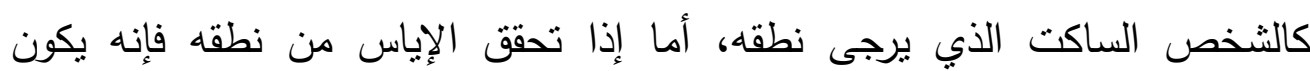
(0) كالأخرس

( (1) وذلك هو مفهوم مذهب المالكية ؛ لأنهم في الأساس يجيزون الإثارة من كل أحد ولو كان قادرا

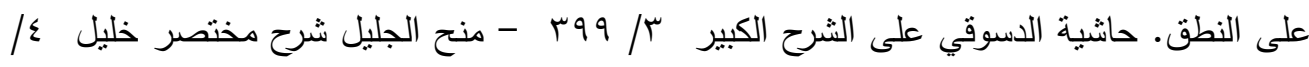

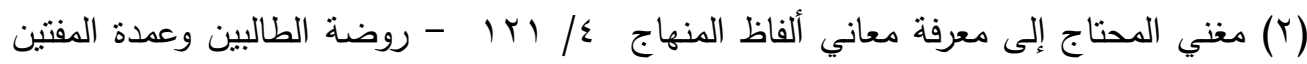

$$
\begin{aligned}
& \text { rIV/T }
\end{aligned}
$$

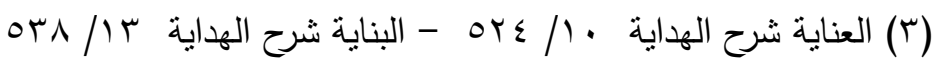

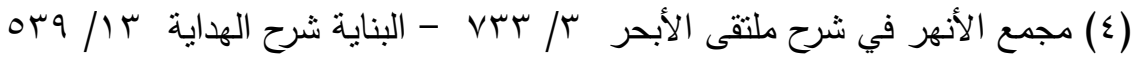

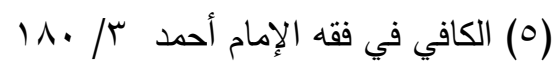




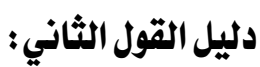

استدل أصحاب القول الثاني على الاعتداد بإنشارة معتقل اللسان مطلقا من دون نوقف على الإياس من نطقه بدليل من المعقول

وييانه: أن من طرأ عليه اعتقال اللسان يصدق عليه أنه عاجز عن النطق فتقبل إثارته كالأخرس (') ؛ لأن عدم قدرة الأخرس على النى اعنى هي العلة في الاعتداد بإنشارته، وهي بلا شك تتسحب إلى معتقل اللسان.

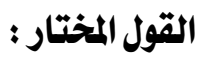

تميل النفس إلى ترجيح القول الثاني وهو مذهب المالكية والثنافعية القائل بالاعتداد بإنشارة معتقل اللسان مطلقا من دون نوقف على الإياس من نطقه؛ لأننا لو لم نعتد بإنشارة من اعتقل لسانه وانتظرنا حتى نتأكد من اليأس من نطقه لأدى ذلك إلى لـى لإلى الإضرار به وتعطل معيشته، لأنه وبدون شك بحاجة إلى التعبير عن إرادته بالإثارة كما أن هذا القول هو الذي ينسجم مع قواعد الثريعة الإسلامية القاضية بالتيسير ورفع الحرج عن المكلفين.

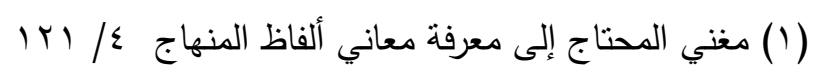




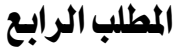 \\ موقف الفقهاء من إشارة الناطق}

إن الثخص الناطق يختلف عن العاجز عن النطق؛ إذ إن هذا الأول يستطيع التعبير

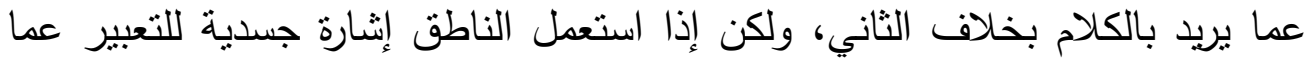

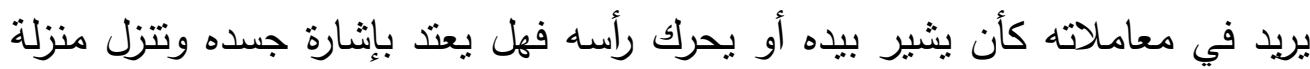

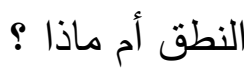
للإجابة عن هذا السؤال نقول بأن الفقهاء- عليهح رحمة الله اختلفوا في هذه المسألة

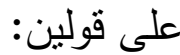

القول الأول: أن الشخص الناطق لا يعتد بإثارة جسده، ولا يمكن إنزالها منزلة النطق منه بل هي لغو لا يلتقت إليها. وهذا قول جمهور الفقهاء من الحنفية (') والثافعية (r) والحنابلة (r)، إلا أنهم استثتوا من ذلك صورا (๕). القول الثاني: أن الثخص الناطق يعتد بإثارة جسده، وتنزل منزلة النطق منه في تزتيب الأحكام إلا في النكاح. وهذا قول المالكية (') وشيخ الإسلام ابن تيمية (؟).

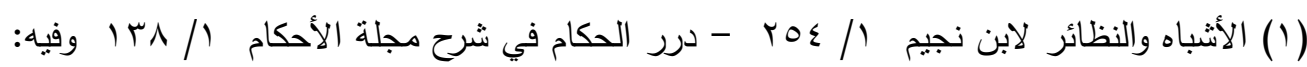
وتحريك القادر على النطق رأسه فغير معتبر إلا إذا أنبع الإثشارة باللفظ الأن

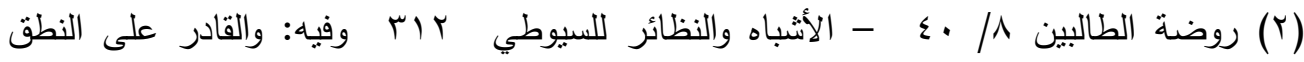
فإثارته لغو

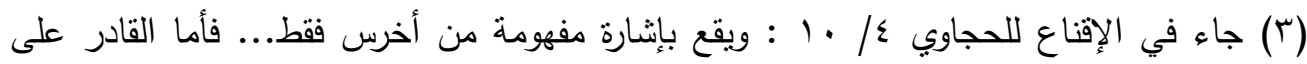

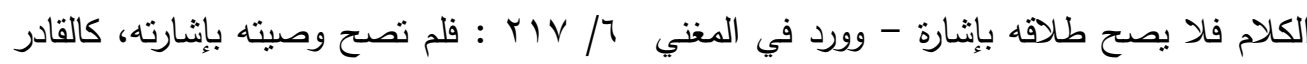
على الكلام (ع) كدخول الإسلام و إثارة الثيخ في رواية الحديث وإثارة المفتي لمن يستفتيه وتأمين الكافر

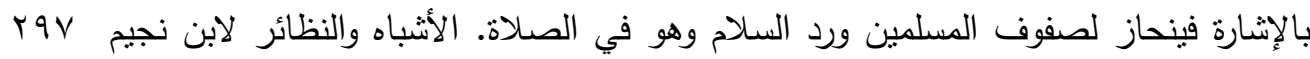

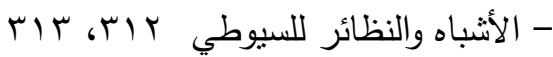




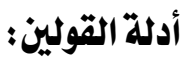

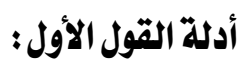

استخل المانعون من اعتبار إثنارة الناطق بدليل عقلي:

ومفاده:

أن الإشارة أنزلت منزلة النطق بالنسبة للعاجز عن النطق للضرورة إلى ذلك، والأمر يختلف في حق الناطق لأنه قادر على الكلام فلا ضرورة في حقه؛ فلا يعتد بإنثارته(؟)

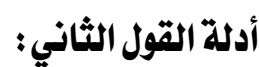

استدل المالكية ومن وافقهم على الاعتداد بإثارة الناطق بشيء من جسده وإنزالها منزلة نطقه بما يلي: من الكتاب :

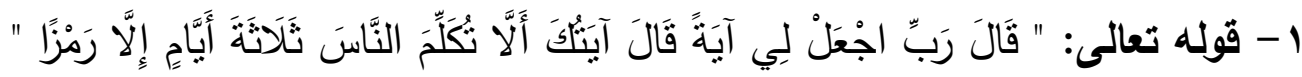

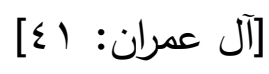

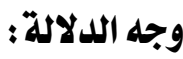

إن هذه الآية تدل دلالة واضحة على إن الإثارة بالجسد من الناطق تتزل منزلة الكلام؛ حيث جعل الله تعالى الرمز طريقة لتعامل زكريا عليه السلام مع قومه، والرمز لغة:

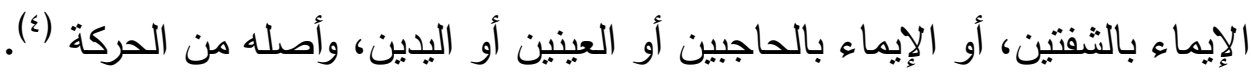

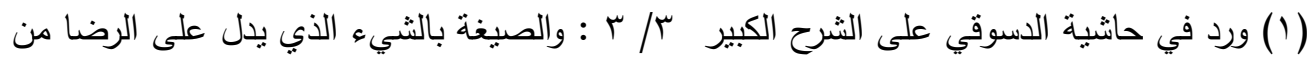

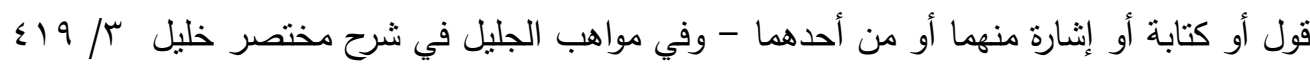

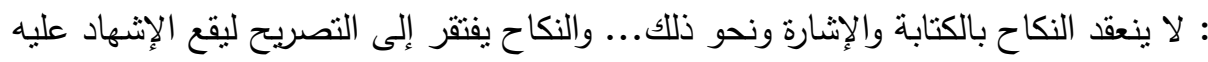

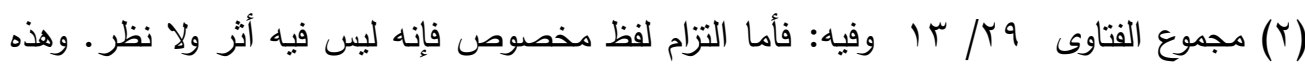

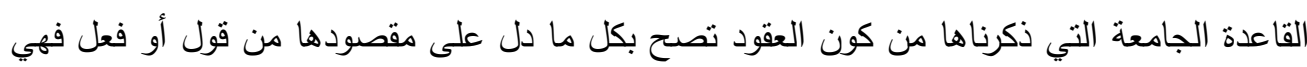
التي تدل عليها أصول الثريعة الغراء ، وهي التي تعرفها القلوب.

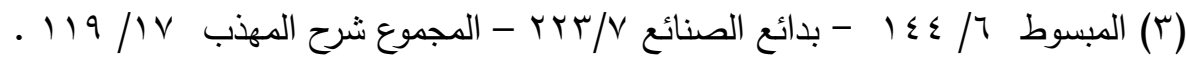

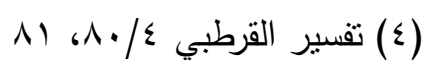




\section{ونوقش هذا الدليل :}

بأن زكريا عليه السلام كان يتعامل مع الناس بالإثارة لأن الهه تعالى حبس لسانه، فكان لا يستطيع أن يكلم أحدا رغم أنه سوي صحيح ليس به خرس، فكان يسبح ويقرأ التوراة، فإذا أراد كلام الناس لم يسنطع أن يكلمه؛ فالإثارة بالنسبة إليه نزلت منزلة الكلام

(1) للضرورة

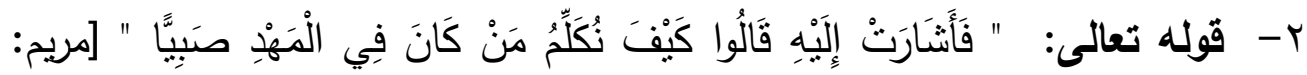
[ra

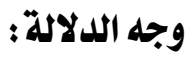
تدل هذه الآية بطريقة لا ريب فيها على الاعتداد بإثارة الناطق وأنها تنزل منزلة الكلام

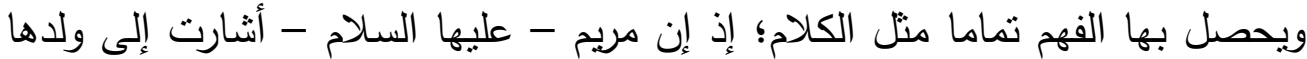

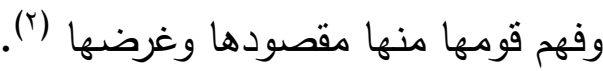

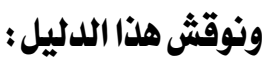
بأن الإثارة من مريم قامت مقام الكلام للضرورة؛ فلم تترك الكلام باختيارها؛ لأن الله تعالى أمرها بترك الكلام مع من اتههها؛ لأن كلام ولدها سيكون أقوى في إزالة التهمة

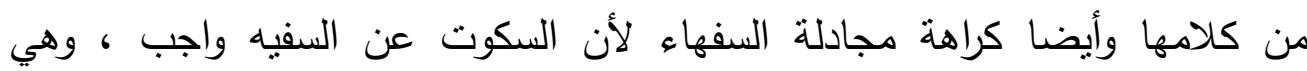

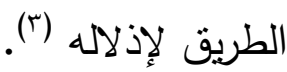
من السنة: ا - عن أبي هريرة ، أن رجلا أتى النبي صلى الله عليه وسلم بجارية سوداء، فقال: يا

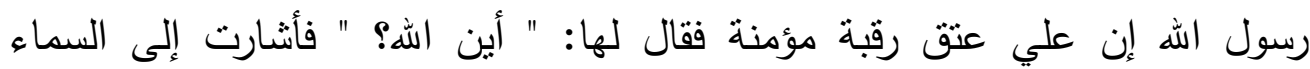
بإصبعها، فقال لها: " فمن أنا؟ " فأثنارت إلى النبي صؤلى الهـ الله عليه وسلم وإلى السماء

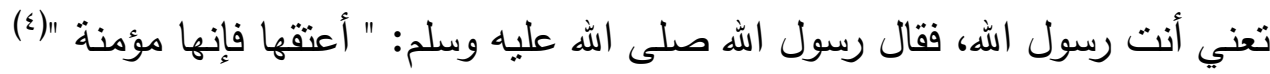

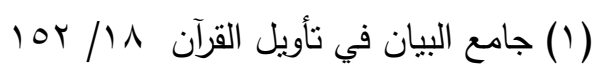

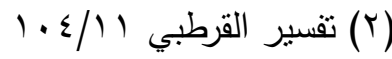

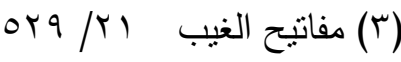

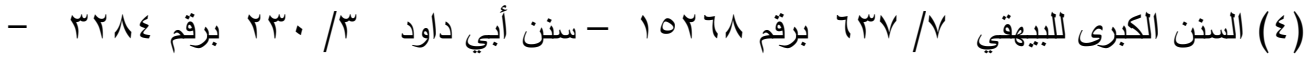

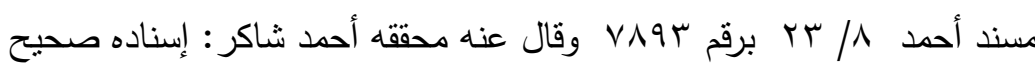


أنه - صلى الله عليه وسلم - أجاز الإسلام بإثارة الناطق، وهو أصل الديانة؛ فبه

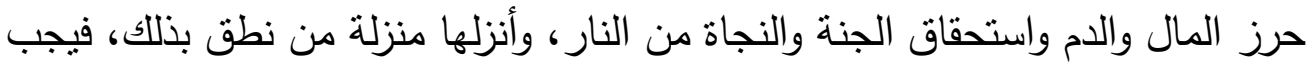

أن تكون الإشارة معتدا بها في سائر التصرفات من باب أولى (').

\section{ويمكن مناقشة هذا الدليل :}

بأن دخول الإسلام بالإشارة تعد من ضمن المسائل التي اتفق الفقهاء جميعا على الاعتداد بها وإنزالها منزلة النطق، فليس هناك محل للاستخلال بها. r- عن أنس بن مالك، قال: عدا يهودي في عهر رسول الله صلى الله عليه وسلم على جارية، فأخذ أوضاحا كانت عليها، ورضخ رأسها فأتى بها أهلها رسول الله صلى فلى الله عليه وسلم وهي في آخر رمق وقد أصمتت، فقال لها رسول الله صلى الله عليه وسلح: 》من قتلك؟ه فلان لغير الذي قتلها، فأشارت برأسها: أن لا، قال: فقال لرجل

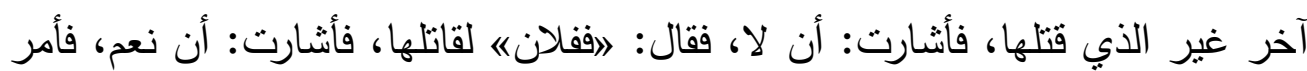

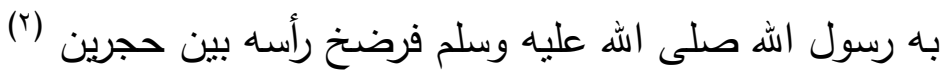

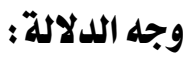
أن النبي - صلى الله عليه وسلم - أقام إثارة الجارية مقام الكلام واعتد بها؛ مما يدل على ترتيب الأحكام على إثنارة الناطق المفهمة.

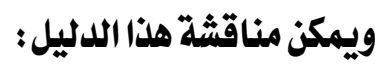
بأن تلاك الجارية التي اعتدي عليها اليهودي بأن أخذ أوضاحها - وهو الحلي من الفضة - ورضخ رأسها - أي كسره - لما أنى بها أهلها للنبي - صلى الله عليه وسلم - كانت في آخر ردق لها، وكانت عاجزة عن الكلام؛ بدليل ما ورد في الحديث أنها أصمتت: أي حدث لها خرس في لسانها مع حضور ذهنها (r)، وهذا يدل على وأنها

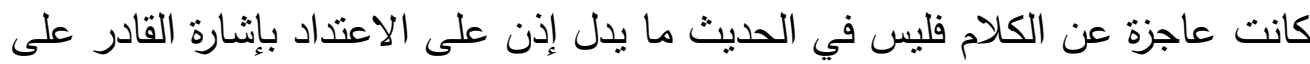
النطق

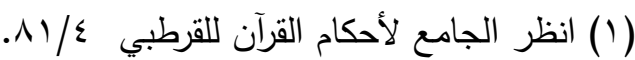

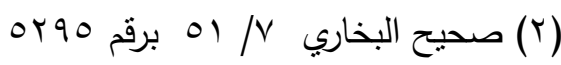
(r) فتح الباري شرح صحيح البخاري 9 / 9 / 
r - عن زينب بنت جحش زوج النبي صلى الله عليه وسلم، قالت: خرج رسول الله

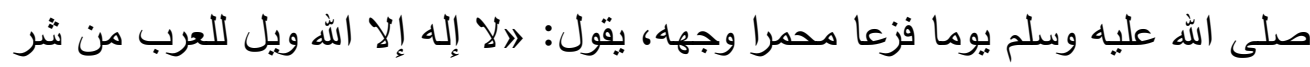
قد اقترب، فتح اليوم من ردم يأجوج ومأجوج مثل هذهه وحلق بإصبعه الإبهام، والتي

تليها (1)

وجه الدلالة:

في هذا الحديث الثربف دليل واضح على إقامة الإثارة من الناطق مقام الكلام بدليل اعتماده صلى الله عليه وسلم عليها في التعبير عن مراده.

ونوقش الاستدلال بهذا الدليل:

بأن الإشارة في الحديث مقترنة بالعبارة وليست متجردة عنها، وقد ورد في كتب الققهاء

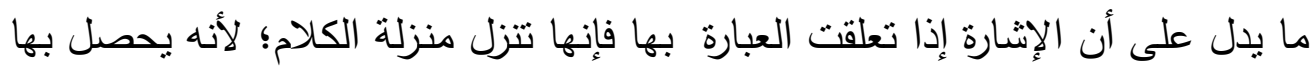
ما وضع له الكلام وهو الإعلام (r). من المعقول: - مان

وييانه: أن الرضا المشترط في العقود والتصرفات هو الذي دل عليه العرف، سواء دل

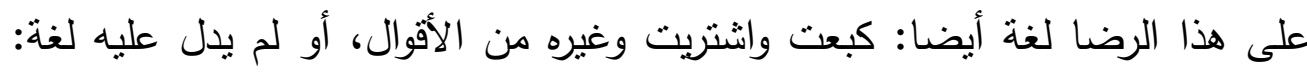
كالكتابة والإشارة والمعاطاة (r).

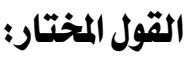
بعد عرض قولي الفقهاء في هذه المسألة تميل النفس إلى اختيار قول المالكية القائل

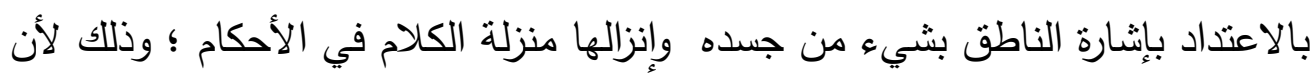

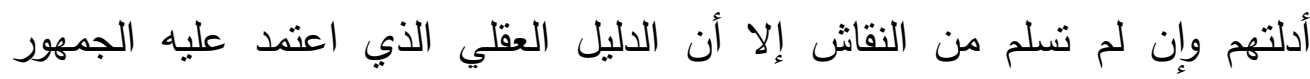

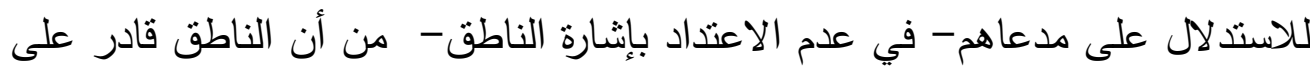
التعبير عن إرادته عن طريق الكلام بخلاف الثخص العاجز عن النطق فليس لله طريق في التعبير عن إرادته سوى الإشارة فأنزلت الإشارة بالنسبة له منزلة النطق للضرورة إلى ذلك، ولا ضرورة للناطق.

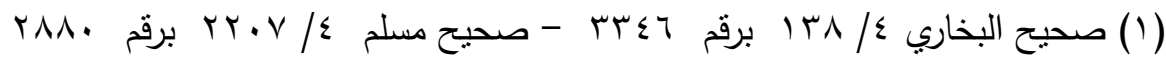

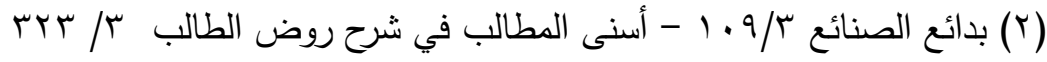

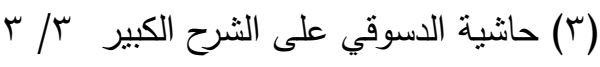


يمكن مناقشته: بأن الناطق قد يحتاج إلى الإشارة من غير عجز عن النطق كما لو

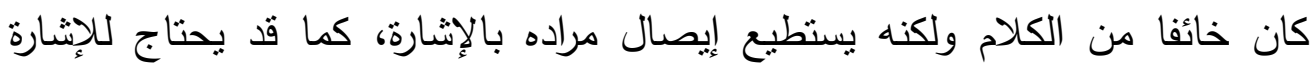

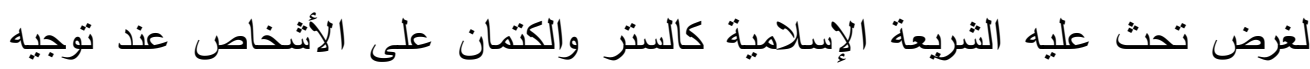

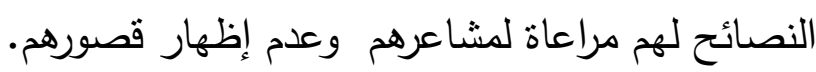
كما أن القائلين بعدم الاعتداد بإثارة الناطقين قد استثثوا صورا كثثرة اعتبروا فيها

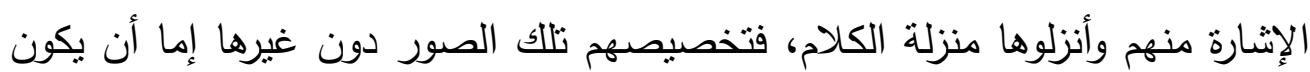

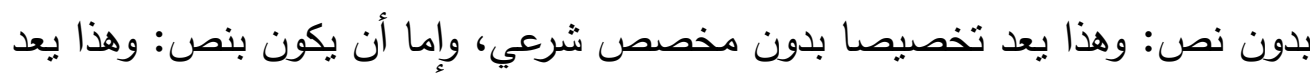
جمودا وإهدارا لمبدأ القياس الذي يقتضي إعطاء ما لم يرد فيه نص حكم ما ورد فيه ولنه نص إذا اشتركا في العلة.

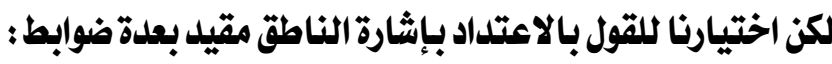

الضابط الأول: أن تكون إثارة الناطق بشيء من الجسد في الحدود المتوافقة مع أعراف الناس وعاداتهم؛ لأنه من الأصول المقررة في الثريعة الإسلامية أن " العادة

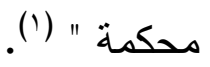

وعادة الناس أحيانا تقتضي قبول الإشارة من الناطق وإنزالها منزلة الكلام، كما لو كانت من شخص بعيد في المسافة ولا يريد رفع صوته، أو كانت من شخص قريب الإنان من لكنه أكبر

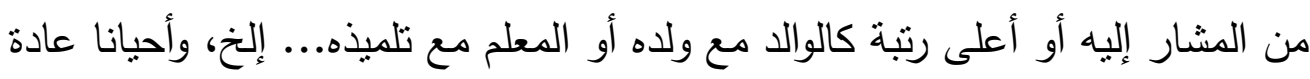

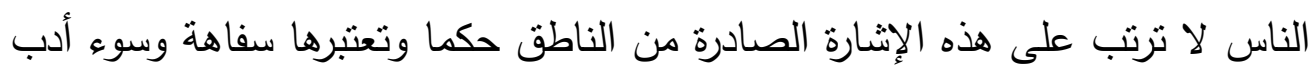
كما لو كانت من الصغير للكبير أو المرعوس للرئيس.

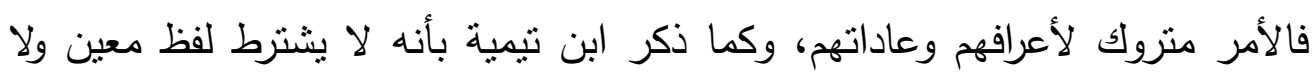
فعل معين يدل على التراضي وعلى طيب النفس، بل إن عادات الناس الجارية في أقوالهم وأفعالهم يعلم منها بالاضطرار معرفتهم التراضي وطيب النفس بطرق متعددة(r)

(1) الأشباه والنظائر للسيوطي 19 - قواعد الفقه:محدد عميم الإحسان المجددي البركتي،الناشر:

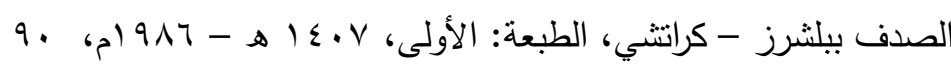

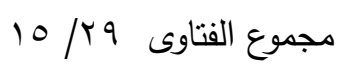


الضابط الثاني: ألا نتزل إثشارة الناطق منزلة الكلام في إنشاء عقد نكاح أو إنهائه؛ لأنه

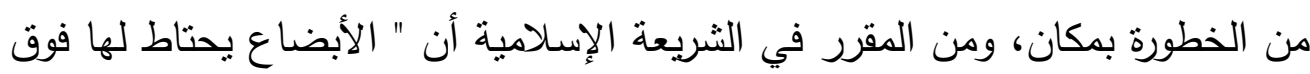

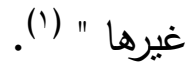

وهناك قاعدة أجمع عليها العلماء: وهي أن الأبضاع أولى بالاحتياط من الأموال (r). فلا بد في منل هذه التصرفات من التعبير بالكلام لإزالة الثبهة الواردة حول الإرادة.

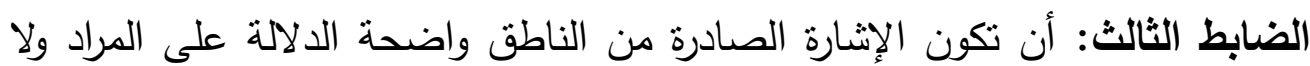
يعتريها غموض ولا يتطرق إليها احتمال. وفي ذللك يقول الثوكاني: " إن الإيماء المفهوم يقوم مقام النطق " (r)، ويقول العناب الحطاب:

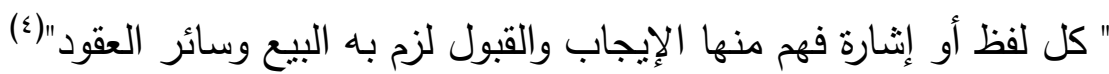

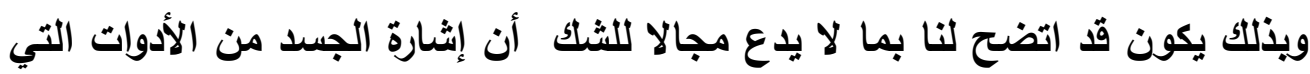

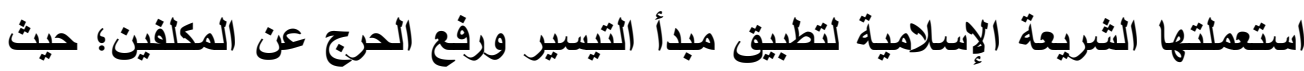
اعتدت بإثارة الأخرس ومعتقل اللسان بل والناطق بقيود معينة كما ذكرنا. هذا وآخر دعوانا أن الحمد لله رب العالمين

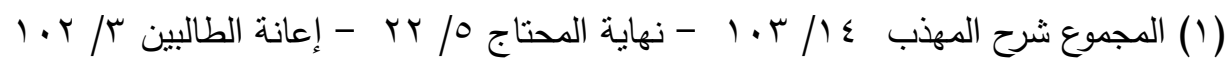

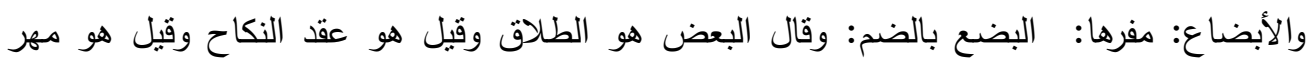

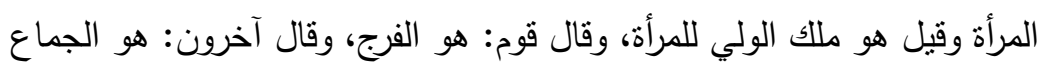

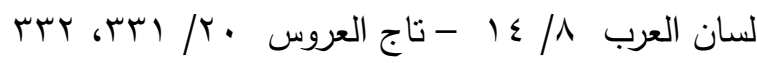

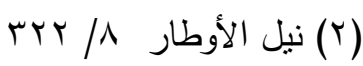

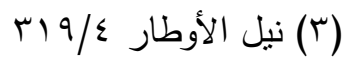

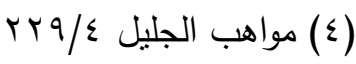




\section{الخـاتمة}

الحمد لله حمدا يليق بجال وجهه وعظيم سلطانه، والصلاة والسلام على النبي المجتبى والرسول المصطفى، وبعد:

فقد عشت خلال هذا البحث في جنة من جنات العلم وروضة من رياضها، وقد أنعم الله تعالى عليً أن جعلني أتتقل من غصن إلى غصن ، ومن شجرة إلى شجرة، فاللهم لا تحرمنا من لذة التفقه في دينك، ولا من شرف خدمة كتابك وسنة نبيك. وقد أمكنني من خلا هذا البحث ملاحظة بعض الأمور، والخروج ببعض النتائج وأستطيع أن أجمل أهمها في النقاط الآتية:

1- يوجد في القرآن الكريم والسنة النبوية نصوص بها ما هو من قبيل إثارة الجسد. r- يعتد شرعا بإنشارة جسد العاجز عن النطق كتعبير عن الإرادة وتتزل منزلة النطق في ترتيب الآثار بشرط أن تكون واضحة ومفهومة، سواء كان هذا العاجز عن النطق مأيوسا من نطقه كالأخرس أو غير مأيوس منه كمعتقل اللسان، وسواء كان قادرا على الكتابة أو عاجزا عنها.

r- يعتد شرعا - على القول المختار - بإنشارة جسد القادر على النطق كتعبير عن الإرادة ونتزل منزلة النطق في ترتيب الآثار ولكن بضوابط ثلاث: أن تكون في الحدود المقبولة عرفا، وألا تكون في إنشاء عقد نكاح أو إنهائه، وأن تكون واضحة الدلالة على المراد ولا يعتربها غموض ولا يتطرق إليها احتمال. ع- بلغ من يسر الثريعة الإسلامية أنها أعملت إثارة الجسد وأباحت التعامل بها في العبادات التي لا يجوز فيها النطق؛ كرد المصلي والمستمع لخطبة الجمعة السلام بالإثارة، وإشارة المصلي لغيره لحاجة ما لم تكثر عرفا، ونهي المستمع لخطبة الجمعة من يتكلم خلالها بالإشارة. 
1- أوصي الباحثين بعقد زمام المبادرة في بحث كل ما لم يتكلم عنه الفقهاء الأجلاء من مسائل مستجدة حتى نكون على أهبة الاستعداد لتجلية الحكم الفقهي فيها، وحتى يستضيء المشرع المصري بما توصلنا إليه فيها عساه أن يجد مبتغاه فيما

بحثناه.

r- أوصي الباحثين الثرعيين في مرحلة الماجستير والدكتوراة بتتاول موضوع إثارة الجسد ولغته بتوسع شديد معرجين في ذلك على كل أبواب الفقه؛ فالموضوع من

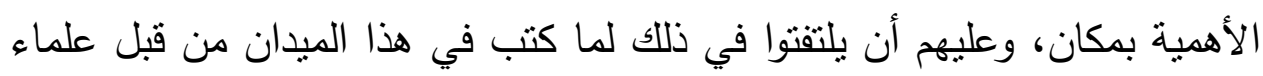
النفس والتتمية البشرية.

وحسبي في ختام هذا البحث أني قد استقرغت الوسع وبذلت الجهد، فإن كنت قد وفقت فمن الله وحده، وأرجو أن يكون حسن مقصدي عذرا لى وشفيعا فيما أخطأت فيه أو قصرت وغفلت.

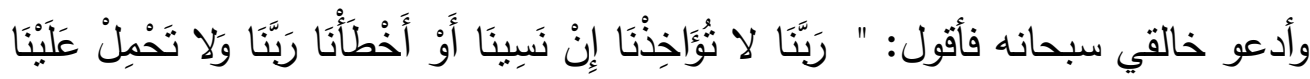

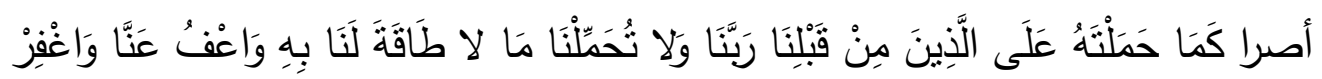

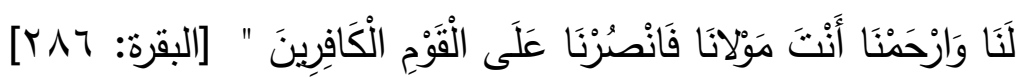
وآخر دعوانا أن الحمد لله رب العالمين، وصلى الله على سيدنا ومولانا محمد وعلى آله وسلم. 


\section{المصادروالمراجع}

- الاتصال والسلوك الإنساني: روبن برنت، ترجمة نخبة من أعضاء كلية التربية

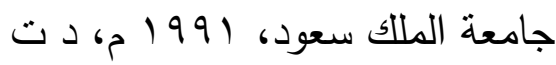
- أحكام القرآن: القاضي أبو بكر محمد بن عبد الله بن العربي المعافري الاشبيلي

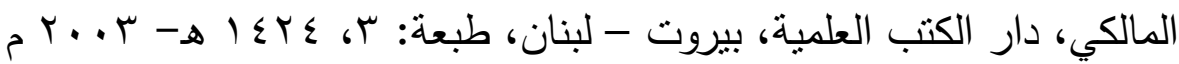
- أحكام القرآن: أبو بكر أحمد بن علي الرازي الجصاص الحنفي، ت: عبد السلام

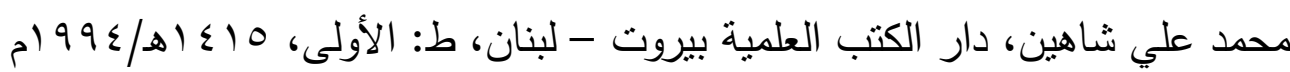

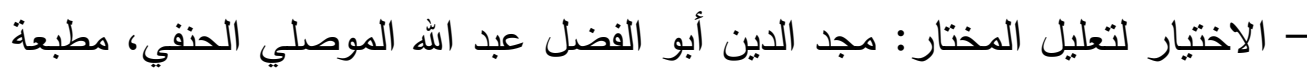

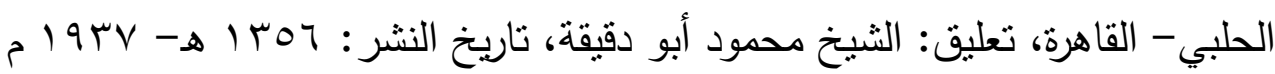
- الأدب المفرد: أبو عبد الله محمد بن إسماعيل بن إبراهيم بن المغيرة البخاري، ت:

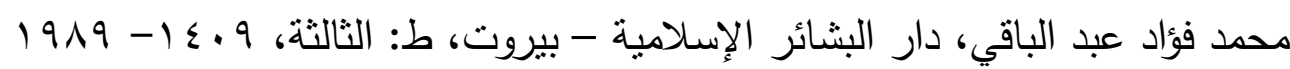

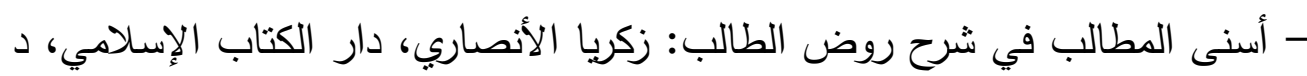
$ت$

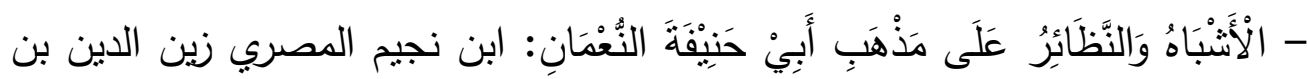

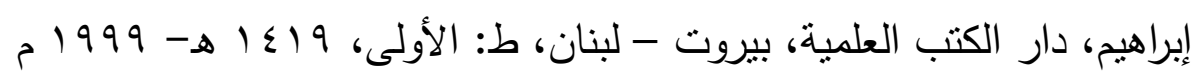
- الأشباه والنظائر : جلال الدين السيوطي عبد الرحمن بن أبي بكر، دار الكتب

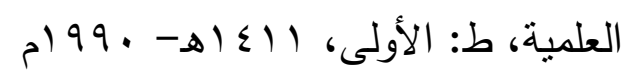

- إعانة الطالبين على حل ألفاظ فتح المعين: أبو بكر عثمان بن محمد شطا الدمياطي

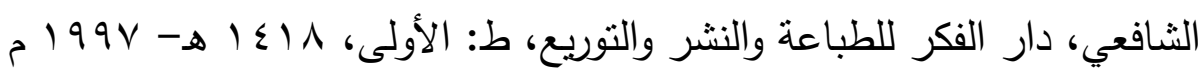
- الإقناع في فقه الإمام أحمد بن حنبل: موسى بن أحمد بن موسى الحجاوي المقدس، ت: عبد اللطيف محمد موسى السبكي، الناشر : دار المعرفة بيروت- لبنان - الإقناع في مسائل الإجماع: أبو الحسن ابن القطان علي بن محمد بن عبد الملك،

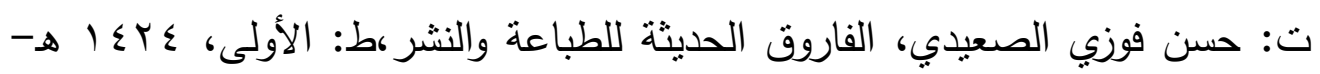
r... 
- البحر الرائق شرح كنز الدقائق: ابن نجيم المصري زين الدين بن إبراهيم، الناشر:

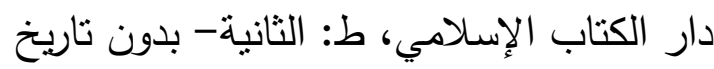

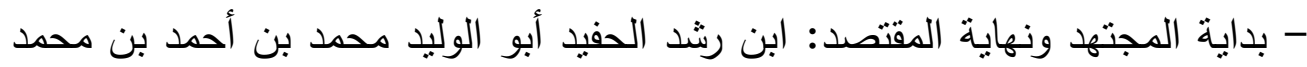

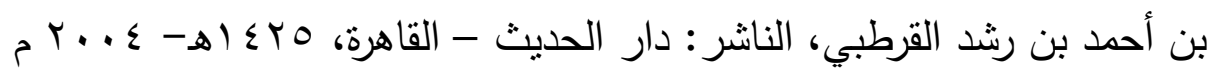

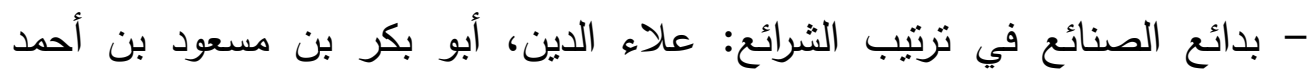

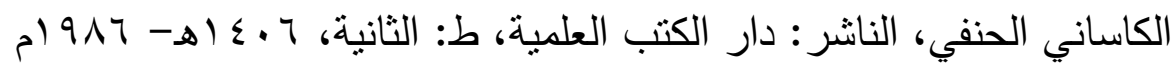
- بذل المجهود في حل سنن أبي داود: خليل أحمد السهارنفوري، تحقيق: تقي الدين

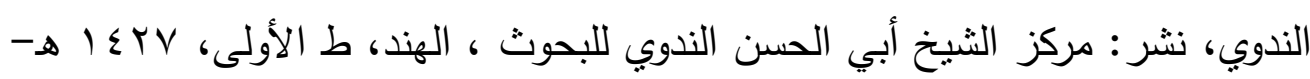
r...T

- بلغة السالك لأقرب المساللك المعروف بحاثية الصاوي على الثرح الصغير: أبو

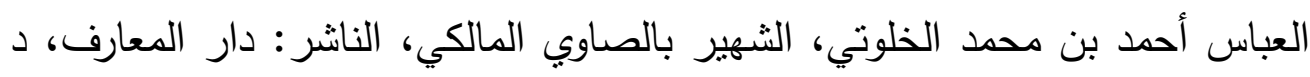

- البناية شرح الهداية: بدر الدين العينى أبو محمد محمود بن أحمد بن موسى الغيتابى

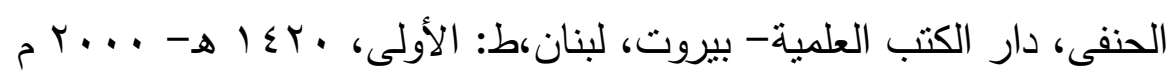

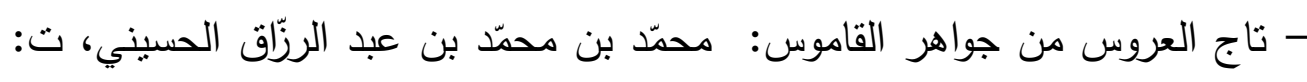
مجموعة من تين، الناشر : دار الهداية - التحرير والتتوير : محمد الطاهر بن محمد بن عاشور، الناشر : الدار التونسية للنشر - تونس - تحفة المحتاج إلى أدلة المنهاج: ابن الملقن الثافعي سراج الدين أبو حفص عمر بن علي، ت: عبد الله اللحياني، ط: دار حراء- مكة المكرمة، ط الأولى، 7 . ؛ اهـ اله - تفسير الشعراوي: محمد متولي الشعراوي، الناشر : مطابع أخبار اليوم - تفسير القرآن العظيم: أبو الفداء إسماعيل بن عمر بن كثير ، ت: سامي بن محمد

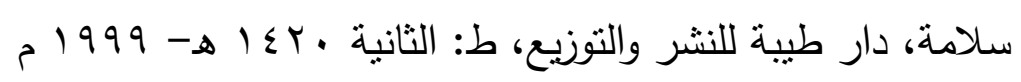


- تقسير القرطبي = الجامع لأحكام القرآن: شمس الدين القرطبي أبو عبد الله محمد بن أحمد بن أبي بكر، ت: أحمد البردوني، دار الكتب المصرية - القاهرة، ط: الثانية، ? 1975

- التواصل غير اللفظي في الإبانة والتواصل نماذج تطبيقية ومقولات كلية: سلاف

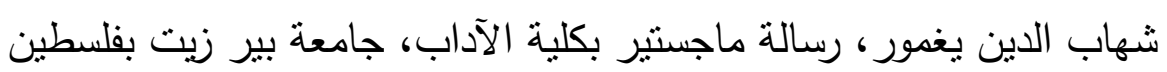
- التوقيف على مهمات التعاريف: زين الدين محمد المدعو بعبد الرؤوف المناوي،

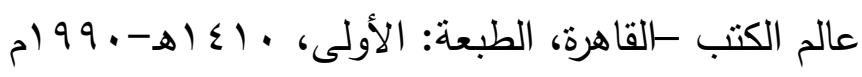
- الثرر الداني شرح رسالة ابن أبي زيد القيرواني: صالح بن عبد السميع الآبي

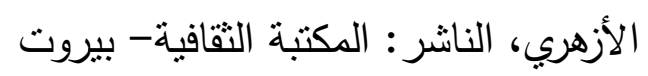
- جامع البيان في تأويل القرآن: أبو جعفرمحد بن جرير بن بزيد بن كثير بن غالب

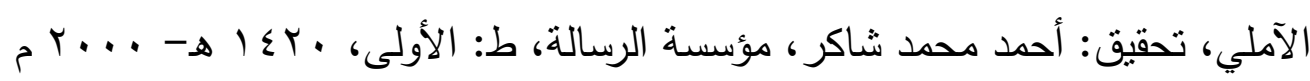
- حاشية الاسوقي على الثرح الكبير: محمد بن أحمد بن عرفة الدسوقي المالكي،

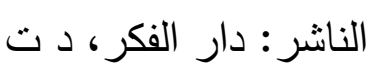

- حاثية الروض المربع شرح زاد المستقنع: عبد الرحمن بن محمد بن قاسم العاصدي

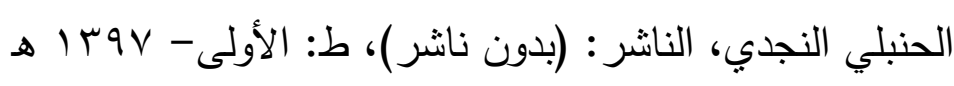
- حاثية الطحطاوي على مراقي الفلاح شرح نور الإيضاح: أحد بن محمد بن إسماعيل الطحطاوي الحنفي، ت: محمد الخالدي دار الكتب العلمية بيروت، ط الأولى لإلى بردي 5) $99 \mathrm{~V}$ - حاشية العدوي على شرح كفاية الطالب الرباني: أبو الحسن، علي بن أحمد بن مكرم

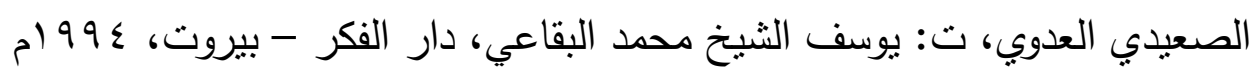
- درر الحكام في شرح مجلة الأحكام: علي حيدر خواجه أمين أفندي، تعريب: فهمي

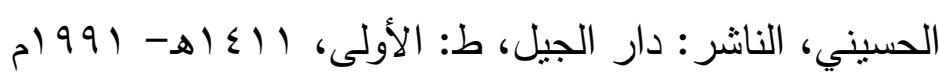


- الذخيرة:أبو العباس شهاب الدين أحمد بن إدربس بن عبد الرحمن المالكي الثهير بالقرافي، الناشر : دار الغرب الإسلامي- بيروت، ط: الأولى، ـ99 19 م - الرخص الشرعية أحكامها وضوابطها، د. وهبة الزحيلي، دار الخير، دمشق، ط ،

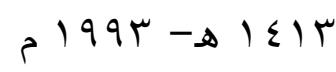
- رد المحتار على الدر المختار = حاثية ابن عابدين: محمد أمين بن عمر بن عبد

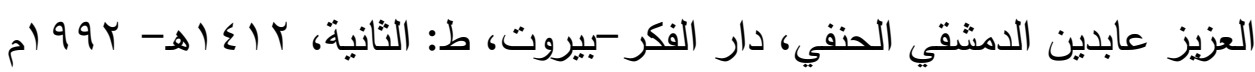
- رفع الحرج في الثريعة الإسلامية ضوابطه وتطبيقاته، د. صالح بن عبد الله بن الهن

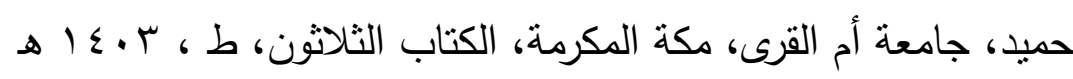
- رفع الحرج في الثريعة الإسلامية، د. يعقوب عبد الوهاب الباحسين، مكتبة الرشد،

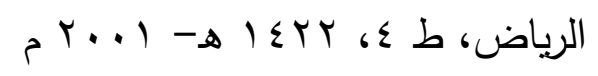
- روضة الطالبين وعمدة المفتين: أبو زكريا محيى الدين يحيى بن شرف النووي، ت:

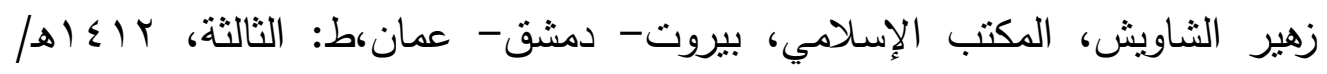

- زاد المعاد في هدي خير العباد: شمس الدين ابن قيم الجوزية محمد بن أبي بكر بن

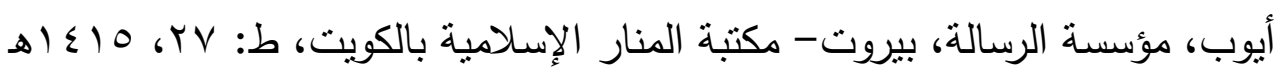

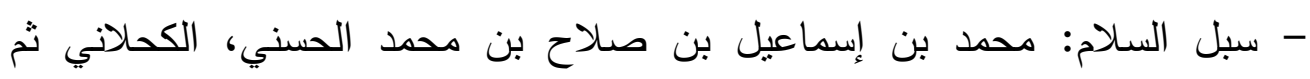

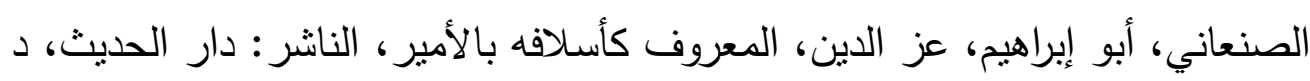

- السراج الوهاج على منن المنهاج: العلامة محمد الزهري الغمراوي، الناشر: دار

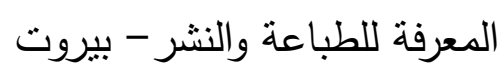
- سنن ابن ماجه: أبو عبد الله محمد بن يزيد القزويني، ت: شعيب الأرنؤوط وآخرون،

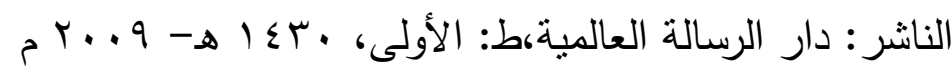


- سنن أبي داود: أبو داود سليمان بن الأثعث بن إسحاق بن بشير الأزدي

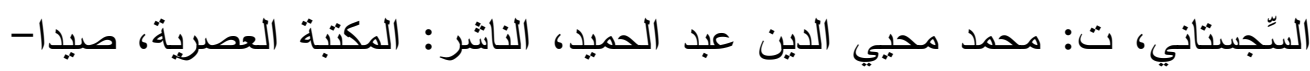
بيروت - السنن الكبرى: أحمد بن الحسين بن علي بن موسى الخُسْرَوْجِدردي الخراساني، أبو

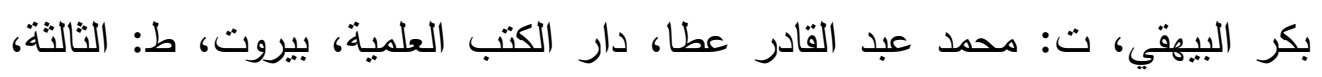

ه $1 \leqslant Y \leqslant$

- سنن الترمذي: محمد بن عيسى بن سَوْرة بن موسى بن الضحالك، الترمذي، أبو

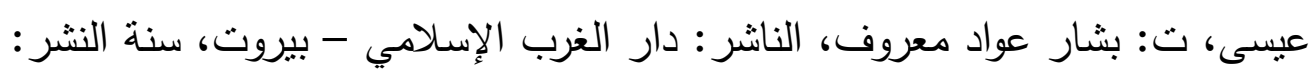
? 1991

- سنن الدارقطني: أبو الحسن علي بن عمر بن أحمد البغدادي الدارقطني، ت: شعيب

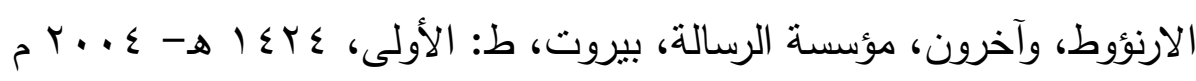
- شرح الزُّرقاني على مختصر خليل: عبد الباقي بن يوسف بؤن بن أحمد الزرقاني

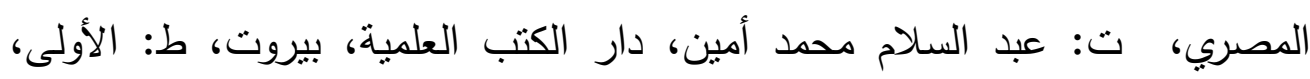
م $r \cdot r$

- الثرح الكبير على منن المقنع: عبد الرحمن بن محمد بن أحمد بن قدامة المقدسي

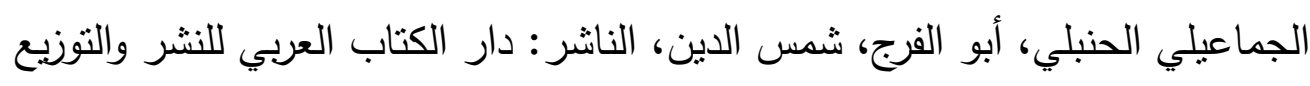
- شرح النووي على صحيح مسلم بن الحجاج، الناشر: دار إحياء التراث العربي بيروت، ط: الثانية، بوس اهـ - شرح مختصر خليل للخرشي: أبو عبد الله محمد بن عبد اله الخرشي المالكي، الناشر : دار الفكر للطباعة - بيروت، ط: بدون طبعة وبدون تاريخ

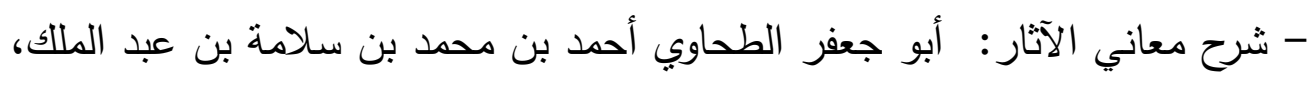

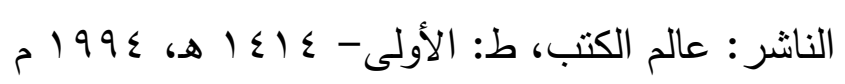
- شعب الإيمان: أبو بكر البيهقي أحمد بن الحسين بن علي بن موسى، تالته مختار

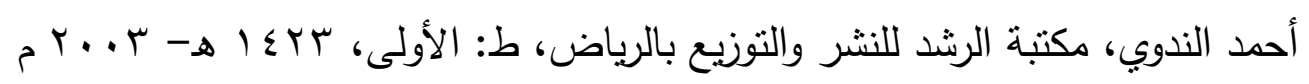


- صحيح ابن حبان: محمد بن حبان بن أحمد بن حبان، ت: شعيب الأرنؤوط،

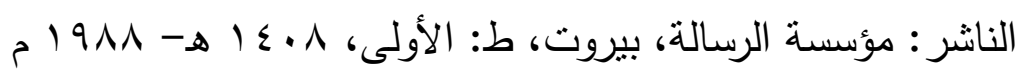
- صحيح ابن خزيمة: أبو بكر محمد بن إسحاق بن خزيمة بن المغيرة بن صالح بن

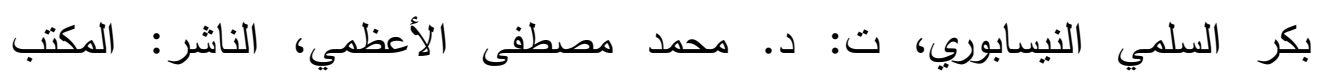

$$
\text { الإسلامي - بيروت }
$$

- صحيح البخاري: أبو عبداله محمد بن إسماعيل البخاري الجعفي، ت: محمد زهير

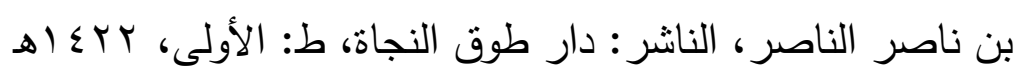
- صحيح مسلم: أبو الحسن مسلم بن الحجاج القشيري النيسابوري، ت: محمد فؤاد

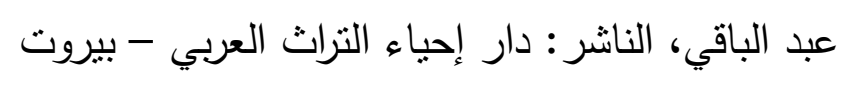
- طرح التثريب في شرح التقريب: أبو الفضل زين الدين عبد الرحيم بن الحسين العراقي، الناشر: ط المصرية القديمة- وصورتها دور عدة منها - العزيز شرح الوجيز المعروف بالثرح الكبيز : أبو القاسم الرافعي عبد الكربم بن محمد دوده

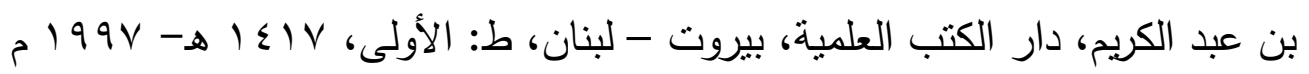

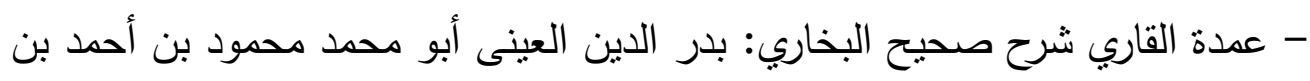

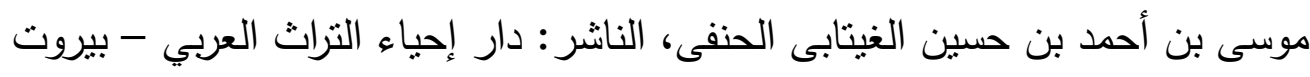

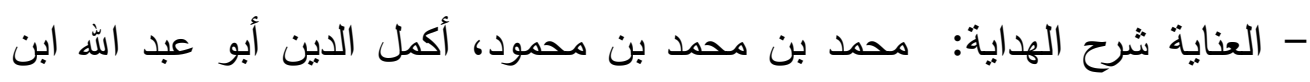
الثيخ شمس الدين ابن الثيخ جمال الدين الرومي البابرتي، الناشر : دار الفكر ، د ت

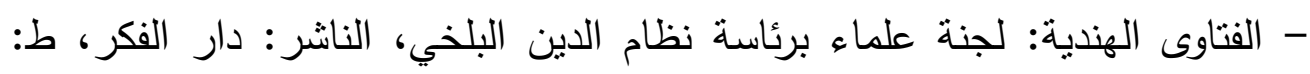

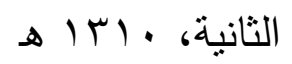
- فتح الباري شرح صحيح البخاري: المؤلف: أبو الفضل أحمد بن علي بن حجر

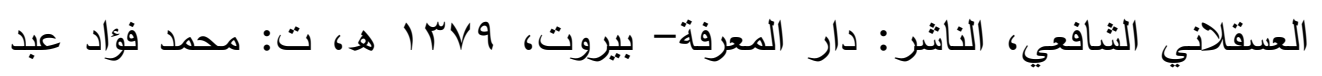
الباقي 
- فتح الباري شرح صحيح البخاري: زبن الدين عبد الرحمن بن أحمد بن رجب الحنبلي، ت: محمود بن شعبان وآخرون، الناشر: مكتبة الغرباء الأثرية بالمدينة

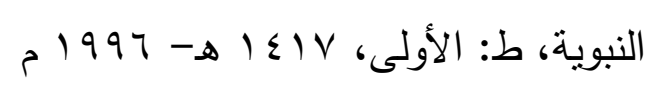

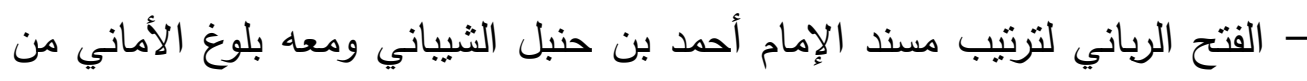
أسرار الفتح الرباني: أحمد بن عبد الرحمن بن محمد البنا الساعاتي، دار إحياء التراث

$$
\text { العربي، ط: الثانية }
$$

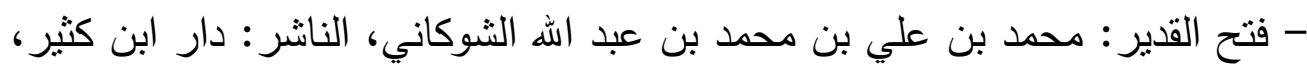

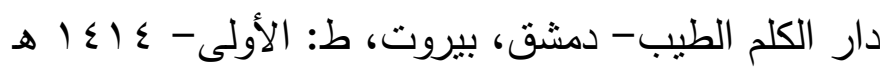

- الفروع ومعه تصحيح الفروع لعلاء الدين المرداوي: شمس الدين أبو عبد الله محمد بلدي بن مفلح بن محمد بن مفرج الحنبلي، ت: عبد الله بن عبد المحسن التركي، مؤسسة

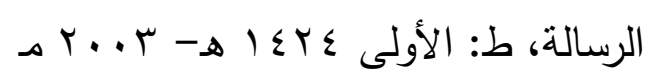

- الفروق = أنوار البروق في أنواء الفروق: القرافي أبو العباس شهاب الدين أحمد بن

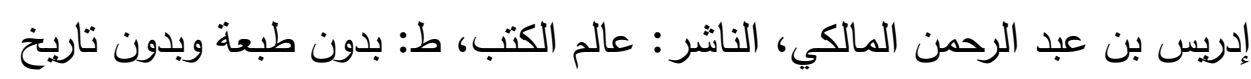
- الفواكه الدواني على رسالة ابن أبي زيد القيرواني: شهاب الدين الدين النفراوي الأزهري

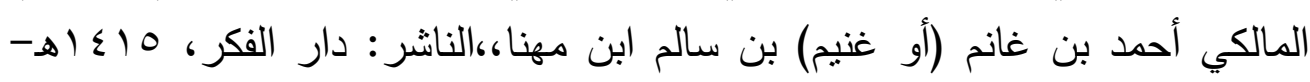
م) 990

- فيض القدير شرح الجامع الصغير : زين الدين محمد المدعو بعبد الرؤوف المناوي

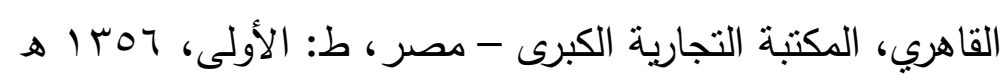

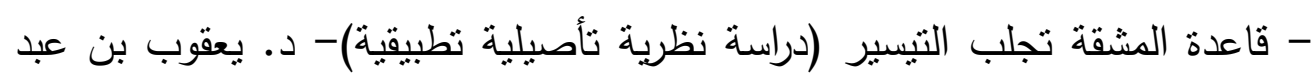

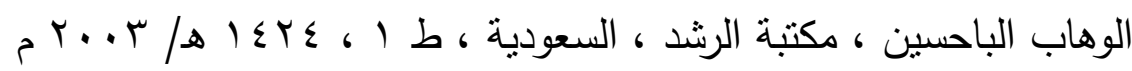

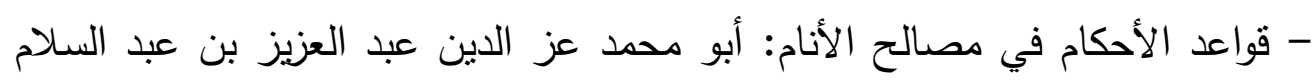
الملقب بسلطان العلماء، ت: طه عبد الرؤوف سعد، الناشر : مكتبة الكليات الأزهرية -

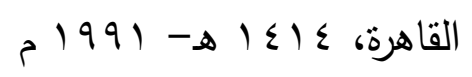
- قواعد الفقه:محد عميم الإحسان المجدي البركتي،الناشر: الصدف ببلشرز -

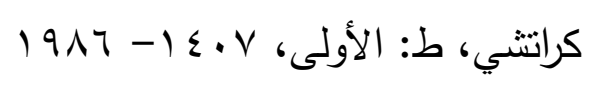


- الكافي في فقه الإمام أحمد: ابن قدامة المقدسي أبو محمد موفق الدين عبد الله بن

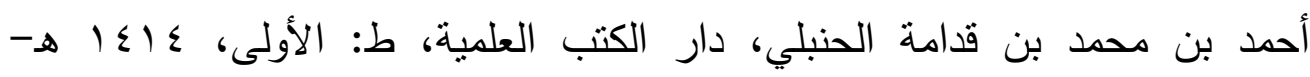

- كثاف القناع عن منن الإقناع: منصور بن يونس بن صلاح الدين ابن حسن بن إدريس البهوتى الحنبلى، الناشر : دار الكتب العلمية - كنز العمال في سنن الأقوال والأفعال: علاء الدين علي بن التن حسام الدين الثهير

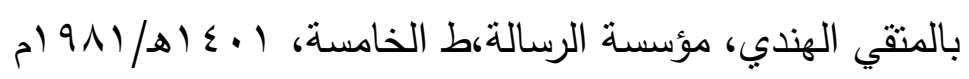
- الكوكب الوهاج شرح صحيح مسلم: محمد الأمين بن عبد الهه الأُرَمي العَلَوي الهَرَري

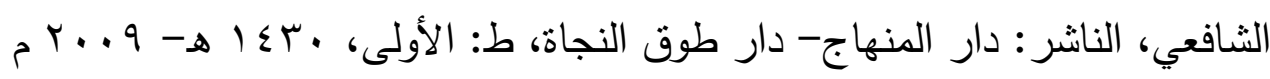

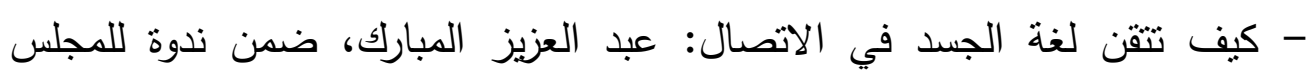

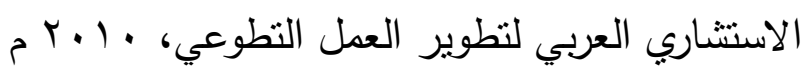
- اللباب في الجمع بين السنة والكتاب: جمال الدين أبو محمد علي بن أبي يحيى زكريا بن مسعود الأنصاري، ت: محمد فضل المراد، الدار الثامية بدمشق،ط: الثانية،

\&

- لسان العرب: محمد بن مكرم بن على، أبو الفضل، جمال الدين ابن منظور

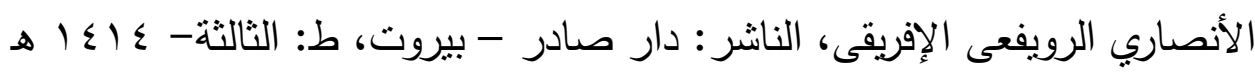
- لغة الجسد: يوليوس فاست، ترجمة: عادل كوريكس، دار نوافذ للاراسات والنشر ،

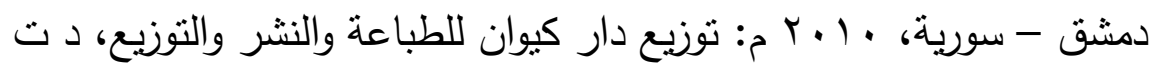
- لغة الجسد في برامج الرسوم المتحركة " دراسة تحليلية في النسخة العربية من برنامج مغامرات عدنان ": هيثم منصور عبد القادر عبندة، رسالة ماجستير في الإعلام، كلية

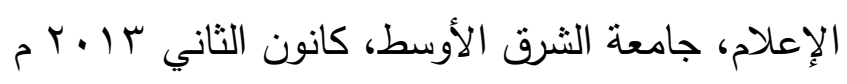
- لغة الجسد وأثرها على إنجاز أهداف التفاوض التجاري دراسة ميدانية: عقبة الصباغ، رسالة ماجستير في التسويق، كلية الاقتصاد بجامعة حلب، 0 ـ ب م 
- المبدع في شرح المقنع: برهان الدين إبراهيم بن محمد بن عبد الله بن محمد ابن

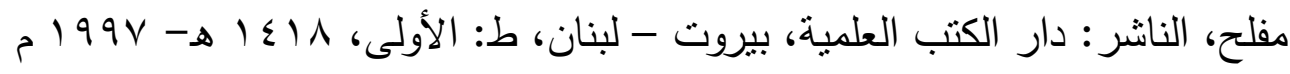
- المبسوط: محمد بن أحمد بن أبي سهل شمس الأئمة السرخسي، الناشر: دار

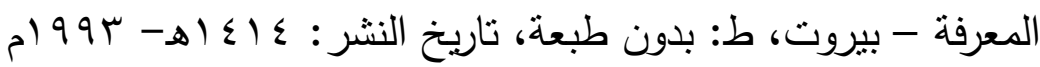
- مجمع الأنهر في شرح ملتقى الأبحر : عبد الرحمن بن محمد بن سليمان المدعو بشيخي زاده، المعروف بداماد أفندي، الناشر : دار إحياء التراث العربي، د ت - مجموع الفتاوى: تقي الدين أبو العباس أحمد بن عبد الحليم بن تيمية، ت: عبد الرحمن بن محمد بن قاسم، الناشر: مجمع الملك فهد لطباعة المصحف الثريف،

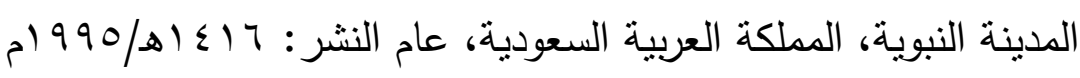
- المجموع شرح المهذب: أبو زكريا محيي الدين يحيى بن شرف النووي، دار الفكر

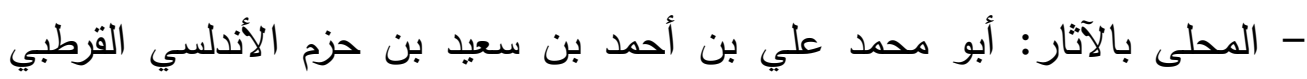
الظاهري، الناشر: دار الفكر - بيروت، ط: بدون طبعة وبدون تاريخ - مختصر الإنصاف والثرح الكبير:محمد بن عبد الوهاب بن سليمان التميمي النجدي، ت: عبد العزيز بن زيد الرومي، وآخرون،الناشر: مطابع الرياض -

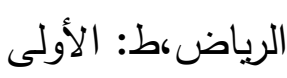
- مدارج السالكين بين منازل إيالك نعبد وإيالك نستعين: محمد بن أبي بكر ابن قيم

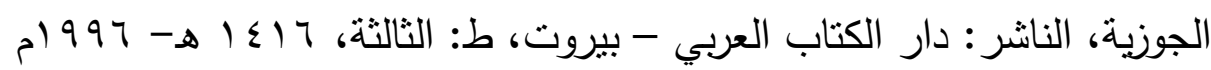

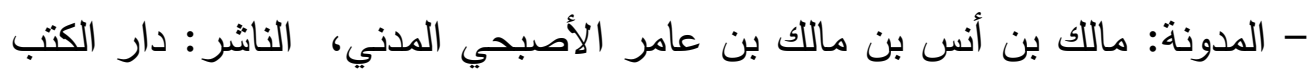

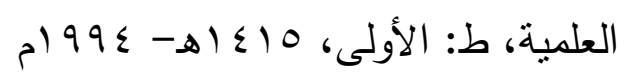
- مرشد ذوي الحجا والحاجة إلى سنن ابن ماجه: محمد الأمين بن عبد اله بن يوسف الها

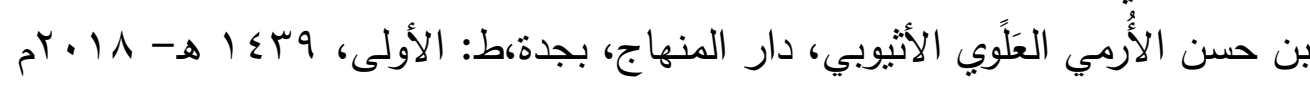
- المستدرك على الصحيحين: أبو عبد الله الحاكم محمد بن عبد الله بن محمد بن بن الهي

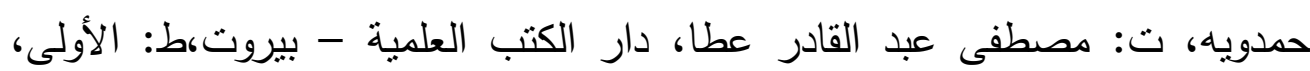
$199 .-1 \leqslant 11$ 
- مسند أبي بعلى: أبو بعلى أحمد بن علي بن المثنى بن يحيى التمبي، ت: حسين

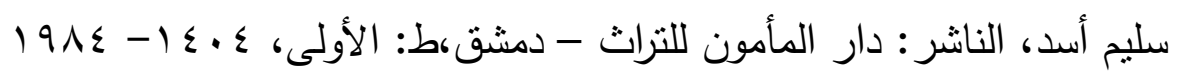
- مسند الإمام أحمد بن حنبل: أبو عبد الله أحمد بن محمد بن حنبل الثيباني، ت:

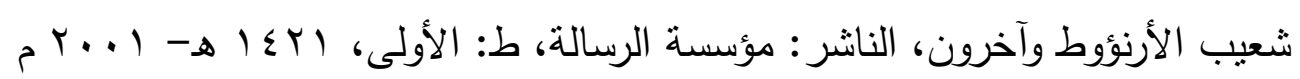
- مصباح الزجاجة في زوائد ابن ماجه: أبو العباس شهاب الدين أحمد بن أبي بكر بن إسماعيل الثافعي، ت: محمد المنتقى الكثناوي، دار العربية - بيروت، ط: الثانية، ه $1 \leq \cdot r$

- المعجم الأوسط: أبو القاسم الطبراني سليمان بن أحمد بن أيوب بن مطير اللخمي الثامي، ت: طارق بن عوض الله بن محمد، وآخرون، الناشر : دار الحرمين - القاهرة - المعجم الكبير: أبو القاسم الطبراني سليمان بن أحمد بن أيوب بن مطير اللخمي الثامي، ت: حمدي بن عبد المجيد السلفي،دار النشر : مكتبة ابن تيمية - القاهرة - معجم اللغة العربية المعاصرة: د أحمد مختار عبد الحميد عمر • بمساعدة فريق

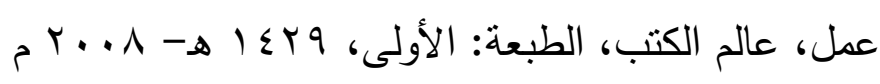
- معجم منن اللغة (موسوعة لغوية حديثة): أحمد رضا، دار مكتبة الحياة - بيروت، ه I H. - المعونة على مذهب عالم المدينة 》الإمام مالك بن أنس《: أبو محمد عبد الوهاب بن علي بن نصر الثعلبي المالكي، ت: حميش عبد الحقّ، المكتبة التجارية، مكة المكرمة - مغني المحتاج إلى معرفة معاني ألفاظ المنهاج: شمس الدين، محمد بن أحمد الخطيب الثربيني الثافعي، الناشر: دار الكتب العلمية،ط: الأولى، 0 إهـ 2) $99 \varepsilon$

- المغني : أبو محمد موفق الدين عبد الله بن أحمد بن محمد بن قدامة الجماعيلي

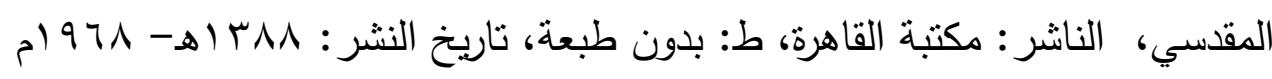


- مفاتبح الغيب = التفسير الكبير : فخر الدين الرازي، الناثر : دار إحياء التراث العربي

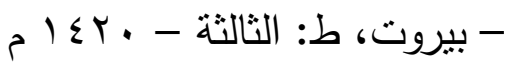
- منار السبيل في شرح الدليل: ابن ضويان، إبراهيم بن محمد بن سالم، ت: زهير الثاويش، الناشر : المكتب الإسلامي، ط: السابعة 9 ، ع 1 هـ-919 (م - - منار القاري شرح مختصر صحيح البخاري:حمزة محمد قاسم، راجعه: الثيخ عبد القادر الأرناؤوط، الناشر: مكتبة دار البيان، دمشق - . 1 1 هـ ـ 199 م - المنثور في القواعد الفقهية: أبو عبد الله بدر الدين محمد بن عبد الله بن بهادر

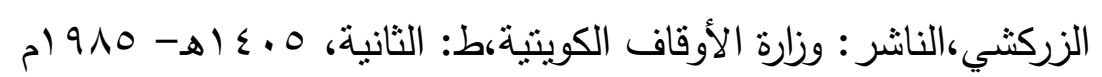
- منح الجليل شرح مختصر خليل: أبو عبد الله المالكي محمد بن أحمد بن محمد

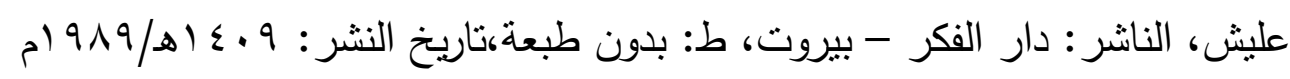
- المنهاج شرح صحيح مسلم بن الحجاج: أبو زكريا محيي الدين يحيى بن شرف النووي، الناشر : دار إحياء التراث العربي - بيروت، ط: الثانية، بوسا - مهارات الاتصال الفعال: د/ محمود فتوح محمد سعدات، الناشر : الألوكة، 11 مب م - المهذب في فقة الإمام الثافحي: أبو اسحاق إبراهيم بن علي بن يوسف الثيرازي، الناشر : دار الكتب العلمية

- الموافقات: إبراهيم بن موسى بن محمد اللخمي الغرناطي الثهير بالثاطبي، ت:

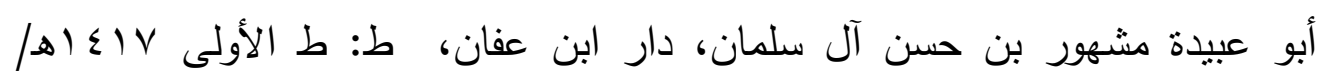

- مواهب الجليل في شرح مختصر خليل: شمس الدين أبو عبد الله محمد بن محمد بن عبد الرحمن الطرابلسي المعروف بالحطاب المالكي، دار الفكر، ط: الثالثة، ب إع (اهـ ค) $99 r$ - نهاية المحتاج إلى شرح المنهاج: شهاب الدين الرملي محمد بن أبي العباس أحمد

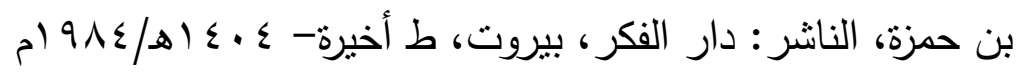


- نهاية المطلب في دراية المذهب: إمام الحرمين عبد الملك بن عبد الله بن يوسف

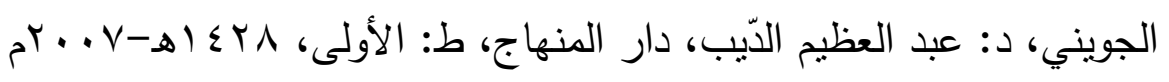
- نيل الأوطار: محمد بن علي بن محمد بن عبد الله الثوكاني اليمني، ت: عصام الدين الصبابطي، الناشر : دار الحديث، مصر، ط: الأولى، باء؛ (هـ- بو9 (م 